\title{
The Consequences of Quotas: Assessing the Effect of Varied Gender Quotas on Legislator Experience in the European Parliament
}

\author{
Andrea Aldrich, Yale University \\ William T Daniel, Francis Marion University
}

\begin{abstract}
This article explores the consequence of quotas on the level of diversity observed in legislators' professional and political experience. We examine how party system and electoral system features that are meant to favor female representation - such as gender quotas for candidate selection or placement mandates on electoral lists - affect the composition of legislatures, by altering the mix of professional and political qualifications held by its members. Using data collected for all legislators initially seated to the current session of the European Parliament (EP) - one of the largest and most diverse democratically elected legislatures in the world, we find that quotas eliminate gendered differences in experience within the institution, particularly when used in conjunction with placement mandates that ensure female candidates are featured on electoral lists in viable positions. Our findings suggest that electoral institutions can generally help to 'level the playing field' between the backgrounds of men and women in elected office, while also increasing the presence of desirable qualities among EP representatives of both genders.
\end{abstract}




\section{Introduction}

Scholars link increases in the descriptive representation of diverse backgrounds with positive outcomes for representation, writ large. Within this literature, a focus on gender and representation is particularly prominent. Higher levels of women's descriptive political representation boost legitimacy and trust in institutions (Mansbridge 1999), greater political engagement and activism (Barnes and Burchard 2013; Campbell and Wolbrecht 2006; Wolbrecht and Campbell 2007), and increased political knowledge (Fridkin and Kenney 2014). Other works explore more substantive effects for women's descriptive representation within a legislature, such as impacts on legislative output and efficiency (Anzia and Berry 2011; Volden and Wiseman 2014). Yet another body of literature investigates ways to improve women's access to political office, exploring the impact of electoral institutions (Bernauer, Giger, and Rosset 2015; Valdini 2012), candidate selection (Krook 2010b; Luhiste 2015; Pruysers et al. 2017), and gender quotas (Dahlerup and Freidenvall 2010; Krook 2010a; Matland 2006). Research on gender quotas, in particular, has focused on the types that are the most effective in securing elected positions for women (e.g., Schwindt-Bayer 2009), as well as the qualities of women who are selected and then elected, both with and without the use of quotas (Baltrunaite et al. 2014; Davidson-Schmich 2016; Murray 2010; Schwindt-Bayer 2011; Weeks and Baldez 2015). The latter literature tends to focus on the quality of female legislators in terms of political experience and performance in office. In addition, Besley (2017) has even shown that quotas effect the quality of men that are recruited by parties once a gender quota is in effect, raising the competence of male politicians alongside raising the level of female representation. We contribute to this literature by exploring the aggregate impact of quotas on the diversity of political and professional background experience among male and female legislators elected to the European Parliament (EP).

While most scholars would agree that increasing the number of women in office is a normatively desirable development, the use of gender quotas to achieve this outcome is not without controversy. Arguments against the use of gender quotas tend to center on the potential decrease in 
quality brought on by 'quota candidates' or a reduction of merit-based competition that quotas might entail. With respect to merit, opponents of quotas argue that a lack of female representation is simply the result of individual choices made by women not to opt for political careers; artificially inflating the number of women on electoral ballots makes competition more about identity than quality (Baltrunaite et al. 2014; Holzer and Neumark 2000). Another perception of women elected using quotas is that they may not have been able to obtain office on their own and are therefore less qualified to serve (Murray 2010). Not only does this perception discredit women in office, but it suggests that quotas may actually decrease the quality of political institutions on the whole (Lovenduski 2005; Murray 2010). However, research specifically examining the women who enter elected office after the implementation of quotas has shown that these concerns are largely baseless. In fact, most of this literature uses single-country studies to show that "quota women" are not inferior to men or "non-quota women", both in their qualifications for office and in their ability to work within legislatures (Baltrunaite et al. 2014; Murray 2010; Weeks and Baldez 2015).

We expand upon this debate by examining the consequences of gender quotas for the diversity of experience witnessed in a legislature's composition. However, instead of examining the impact of quotas on the competency or qualifications of female legislators, we ask whether the presence of quotas is associated with a different overall composition of legislatures in significant ways. Using the unique electoral structure of the EP, where some members are elected under national and party-level quotas systems and others are not, we are able to draw comparisons between those systems where quotas are associated with no gaps between men and women's professional and political experience those in which quotas continue not to be used. Our analysis speaks to a larger debate on the extent to which quotas are associated with the removal of common barriers to entry for women who run for office in Europe. In general, we find that systems using a combination of quotas and placement mandates, which are rules requiring the nomination of women to winnable constituencies or list positions (Schwindt-Bayer 2009), have more balanced representation between men and women and also higher levels of qualified politicians from both genders. 
The EP makes for an interesting test case for this inquiry. Not only is it among the most gender-equal legislatures in the world, but it is also comprised of directly-elected representatives from 28 liberal democracies and more than a hundred national political parties. While EU law sets a loose, common framework for EP elections, it also provides national parties and electoral systems with a great deal of agency to dictate the terms under which these elections will take place. With respect to the promotion of women in elected office, nine of the $28 \mathrm{EU}$ member states actively incentivize the election of women via gender quotas that are directly required by national electoral law, in addition to dozens of national political parties who do so at an organizational level (Prpic and Chahri 2017).

Using individual-level data on the previous professional and political experience of members of the European Parliament (MEPs), we compare the composition of delegations elected to the EP using quotas, both with and without electoral list placement mandates, to the institution as a whole. We are thereby able to leverage the uniquely diverse electoral features of the EP to assess the impact of quotas on the composition of the parliament in a way that single-country studies cannot, making a unique empirical contribution to the broader literature on gender quotas.

Our findings demonstrate that while gender quotas and other institutional decisions meant to boost the quantity of female representation are significantly associated with indicators of professional experience and political expertise, they are not the direct cause of differences in the experience and expertise of MEPs. In fact, in systems where quotas and placement mandates are in use, differences between men and women tend not to exist, with respect to previous political and professional experience. In addition, we find that systems with quotas contain more experienced MEPs overall, across both males and females, which thereby increases the general quality of the EP. These findings echo the work of scholars from other legislative venues and show that quotas and protocols intended to increase female representation may not only 'open the door' or 'even the playing field' for elected women, but may also more broadly improve the quality of representatives present in the legislature. 


\section{Assessing the Impact of Quotas on Female Representation}

A number of studies have considered the degree to which quotas and other mechanisms for boosting female representation are effective at increasing the number of female representatives, as well as enhancing the quality of representation. We begin by discussing the traditional barriers to entry present in electoral contexts that impact on both the quantity and composition (in terms of experience) of the pool of female candidates in democratic societies. We then focus on gender quotas as one institutional tool to can be used to overcome these barriers.

\section{Improving the Recruitment Environment:}

Women have traditionally faced barriers to election that affect both the supply and demand sides of the political recruitment environment. Among these barriers, electoral systems are one of the most important. At a basic level, the difference between proportional representation (PR) systems and single-member majority districts (SMD) affects women by defining the scope of competition. The nature of this competition also affects both the type of women willing to run and the type of women that parties nominate. SMD and open-list PR systems require women to compete directly against other candidates. In single member districts this is only their opponent, while in open-list PR systems this may be both their fellow party members and opponents from other parties. This means that they compete on their personal merits, either alone or alongside the merits of their group, whereas closedlist PR systems structure competition around the group. This influences the type of candidates that will run for office, because not all women feel qualified to compete in an individual manner. Fox and Lawless (2004) show that women doubt their qualifications to run for office more so than men, even when they are objectively as qualified. Kanthak and Woon (2015) use an experimental design to show that women are more averse to the competitive nature of elections, in general, and are only more likely to run if the private costs of doing so can be eliminated. Accordingly, when women do run, we might expect them to be a particular 'kind' of woman, in terms of their experience, qualifications, and ambition. 
Women who run for office in more individually-competitive electoral systems tend to share similar characteristics and qualifications for office. Schwindt-Bayer (2011), in her study of women in Latin American legislatures, finds that women who win elections for legislative office represent a particular type of candidate. Specifically, she finds that these women tend to represent more traditionally defined 'male' roles. To compete against men, these women are highly educated and have considerable political and professional experience in areas that traditionally lead to political careers. They are also less likely to be married or have a family and are more likely to be politically ambitious. In other words, they are like the men that they run against and may not be providing the 'women's' perspective that descriptive representation is thought to entail.

Being more 'like men' has also shown to be lucrative in elections outside of Latin America. For example, Huddy and Terkildsen (1993) show that candidates with 'masculine' traits are considered more competent in important policy areas like the military and the economy, which can be helpful in winning elections. But displaying masculine characteristics also has a downside. More recent research has shown that voters also prefer female politicians with more traditional family roles, which can put women candidates in a "double bind" (Teele, Kalla, and Rosenbluth 2018). Having the traits similar to men that signal competence and the ambition to run for office may make a female candidate appear less likeable and overall less competitive.

Each of these factors, combined with the fact that women are rarely encouraged to run for office in the way that men are (Fox and Lawless 2004), contributes to an undersupply of women across the board. It's no wonder that women, regardless of their qualifications, are less likely to run for office than men and that legislatures still have relatively fewer women than men overall. So, how can women be encouraged to run for office? Institutional rules, like quotas, can help to create a female-friendly environment to encourage ambitious women.

Parties in a variety of national contexts have therefore experimented with the usage of gender quotas at the nomination stage, where various mechanical thresholds require parties to select certain numbers of female candidates. These quotas may be set as either national law or as internal party 
policies and vary widely from overtly tokenistic schemes to ones meant to ensure full gender parity. What they have in common is a requirement for female candidates that can eliminate some of the more individually competitive aspects of candidate selection in non-quota systems, which encourages a more diverse pool of candidates.

\section{Quotas and the Dynamics of Representation}

That gender quotas can lower barriers in the recruitment environment of elections for women is largely supported in the quota literature. A number of studies examine how electoral laws and policies - particularly gender parity quotas at the recruitment and nomination stage - affect legislator quality within the national political systems of Europe. Allen, Cutts, and Campbell (2016) examine this question within the UK, following the introduction of party-level gender quotas in 1997 . They find that women elected under the new quota system are not significantly different than women who were not nominated under quotas, with respect to their backgrounds, vote totals, and further abilities for political advancement. Similarly, Murray (2010) finds that women's background qualifications and experience, prior to election to the French parliament, were not reduced by the introduction of quotas; there were simply more women listed on the ballot. Such findings suggest that women may not be more (or less) qualified when elected on quotas, but that their 'numerical' representation successfully increased.

The question of whether an increased number of female representatives elected via gender quotas affects the overall background qualities of legislators has also been addressed at some length. Taking advantage of a natural experiment in Italy, where quotas were introduced and then removed, both Baltrunaite et al. (2014) and Weeks and Baldez (2015) find that quotas increased the numbers of women elected to the Italian parliament. In the case of Baltrunaite et al.'s study, the increased number of female representatives corresponded with a heightened level of education across all legislators, while it reduced the number of male legislators without advanced degrees. Weeks and Baldez' work echoes this finding, concluding that gender quotas helped to boost the number of women in national office who had prior local political experience and lowered absenteeism across 
the national legislative body. Somewhat pessimistically, however, these same trends reversed, shortly after the Italian quotas were removed.

In addition, O’Brien and Rickne (2016) show that the strict gender parity required by local Swedish social democratic party boards not only increased women's representation within the party, but also enabled more women to advance into national positions of political leadership more quickly than their colleagues from parties without such regulations. One of the positive externalities of this change in party leadership was the removal of mediocre male party leaders. Besley et al. (2017) suggest that increased competition for male seats after the introduction of a quota made it harder for mediocre leaders to nominate mediocre men in elections and maintain their grip on power in the party. The result was that more competent leaders arose, sometime through the support of women making the most use of the new quotas. These leaders than nominated more competent candidates overall, therefore raising the entire level of quality of candidates across both genders.

Finally, experimental work has demonstrated that the elimination of competition for leadership roles encourages qualified women to seek out these opportunities. Neiderle, Segal, and Vesterlund (2013) argue that the absence of women in high profile and competitive jobs might be caused by the competitive environment, in which highly qualified women choose not to enter competitions that they could win. They use experimental evidence to show that introducing affirmative action policies not only encourages more women to participate in competitive tournaments but also maintains the overall quality of all participants. In a similar study, Kanthak and Woon (2015) test whether women are more sensitive to competitive elections than men, regardless of their objective ability to win or their beliefs about others abilities. They find that even qualified women are averse to electoral competition and show that removing the competitive aspects of elections in favor of volunteer opportunities increases the likelihood that women will step forward as candidates.

In sum, the literature suggests that quota laws and other institutional choices meant to boost gender parity increase the number of female representatives, but do not hurt the quality of 
representation offered by female legislators. Indeed, quotas may even help to raise the quality bar across the bodies in which these rules are found by both introducing competent and quality female candidates and making the nomination of less qualified men more difficult We therefore expect the presence of quotas in European elections to also impact the type of legislator elected from European Union member states that use them.

\section{Contextual Factors and Women's Recruitment}

In addition to institutional rules like quotas, a variety of contextual factors and party characteristics also affect the recruitment environment. At the national level, the inclusion of more women in politics, lower incumbency rates, and overall increased gender equality can encourage more women in office. When women are in elected positions, they serve as role models for other women and girls and encourage political participation (Barnes and Burchard 2013; Campbell and Wolbrecht 2006; Wolbrecht and Campbell 2007). When overall gender equality is high, traditional gender roles and stereotypes about women in office are less pronounced, encouraging more women to seek office (Krook and Norris 2014). Party characteristics such as ideology, the organization of candidates selection, and the number of women activists within the party also play a role (Caul 2001). Here, the literature finds that the most gender-equal legislatures will come from countries in which the recruitment environment is the most positive towards women's issues and gender equality concerns. This cultural predisposition should be helpful to women's recruitment at both the party and at the national level. Furthermore, it suggests that an electoral system that combines proportional representation with gender quotas should be most helpful at increasing women's descriptive representation in legislatures. Having considered the general picture, we now examine how these factors are at play in Europe's largest directly-elected legislature.

\section{Women's Representation in the European Parliament}

In many ways, the EP operates as a microcosm for the comparative study of institutional design in Europe. While MEPs follow a common set of rules and procedures within the assembly, they are elected via systems that vary widely from country to country and come from parties that represent the 
full spectrum of political beliefs present across the continent. Reflective of the European Union's (EU) motto, 'United in Diversity,' EP elections provide an interesting empirical example of the various systems and peoples found across the EU, unified within a singular institution.

However, the EP is also an outlier with respect to female representation. The most-recent May 2014 EP elections produced an all-time high for women's representation at the EU level, with female members of the EP (MEPs) occupying more than a third of seats in the multinational legislative assembly. By the midpoint of the term in 2017, this number had grown to $37.9 \%$ of all MEPs - making the EP one of the world's most gender-equal legislatures. At the same time, only 22 national legislatures - six of which are EU member states - from around the world could boast a higher degree of female representation (Prpic and Chahri 2017). What explains this success in boosting the number of female representatives and what are its consequences for the EP?

Fortin-Rittberger and Rittberger (2015) examine women's recruitment to the EP during the 2009 elections and find that female MEPs benefit from recruitment strategies that allow for centralized party selection mechanisms at a mix of regional and national levels. In other work, they also find that women are more likely to win election to the EP when they come from countries or parties that employ gender quotas, are nominated to closed lists, and come from districts with greater numbers of MEPs (Fortin-Rittberger and Rittberger 2014; Lühiste 2015). While these findings are broadly in keeping with the thrust of the literature that we discuss above, it is particularly interesting to note that, while all EP elections are inherently proportional, the varying sizes of country delegations suggest that some elections are more proportional than others.

Beyond the mechanical effects of differing electoral systems, other scholars examine intraparty differences for the success of women's election to the EP. Lühiste and Kenny (2016) find that while female MEPs are more likely to come from leftist parties, which are more likely to use inclusive quotas, women from more conservative and rightist parties are actually more likely to demonstrate relevant political experience and may be more successful in advancing their legislative careers. Aldrich (2018b) finds that centralization of party organizations affects the likelihood of 
selection and nomination for women candidates to the EP. Chiva (2014) finds that the traditional leftright ideological spectrum is less successful than the pro-/anti-EU dimension in accounting for the presence of female MEPs from Central and Eastern European member states. Her findings suggest that anti-EU parties may view pro-gender equality as a 'Western' norm that is imposed upon parties from the EU. Finally, Xydias (2016) examines the role of the second-order elections model on women's representation and discovers that women MEPs are at a comparative advantage for EP elections when they come from national parties that take the EP less seriously and are therefore less competitive with their candidate selection practices.

While this mixed bag of cultural and institutional variables may make election to the EP more or less difficult for certain types of women, Fortin-Rittberger and Rittberger (2014) also explain how the EP may be a particularly attractive place for women to work, as compared with national political systems. Because EP elections are less competitive, ambitious women can be advantaged in both ballot selection and election times - as parties and voters pay less attention to who is being elected. Because EP elections are all at least somewhat proportional, women do not suffer the high barriers to entry faced in majoritarian elections. And because the EU is more gender-mainstreamed and typically more developed in its gender-equality policies, women MEPs may find a neater substantive fit with EU policymaking. ${ }^{\mathrm{i}}$

In sum, the EP appears to have more female legislators than many national parliaments for the same mix of cultural and institutional reasons that many European legislatures have more female legislators than in other parts of the world. However, given the diverse national systems that coexist within the EP space, every female MEP who benefits from a more gender-equal national political environment and comes from a political party with advantageous selection criteria may also work alongside MEPs from political environments that are less friendly to women's political recruitment. Therefore, we now consider how the sources of variation present in women's selection to the EP may also influence the dynamics of representation on offer there. 


\section{Theorizing the Effect of Gender Quotas on Representative Qualities}

Thus far, we have considered the effect of quotas on women's legislative representation, with a particular emphasis on the intra-institutional diversity of the EP. In this section, we move on to theorize how the varied usage of gender quotas may also have unintended side effects on the qualities that MEPs demonstrate in their work as legislators. While the EP was once viewed as an overly complex and technical institutions with an extraordinary turnover rate among legislators (e.g., Daniel and Metzger 2018), its increased professionalization since the introduction of legislative co-decision with the Council in the early 1990s has led to a growing class of politicians whose primary ambition lies in working for the European body (e.g., Daniel 2015). At the same time, national parties have increasingly used European elections strategically to further their national and European goals (Aldrich 2018a; Pemstein, Meserve, and Bernhard 2015), often favoring incumbent MEPs in the selection of candidates (Meserve, Pemstein, and Bernhard 2018). Nonetheless, incumbent MEPs are not the only politicians recruited for EP elections.

The seniority-driven hierarchies found in many of the EP's internal institutions (Daniel 2013; Ringe 2010; Yoshinaka, McElroy, and Bowler 2010) suggest that national parties should seek out politicians who are prepared to take on the subject matter dealt with at the EP level, as well as to protect career MEPs. While we expect that all parties have the rational incentive to select high quality politicians for office, when it comes to women's recruitment and selection initiatives, we expect that parties using quotas will also feature a higher number of women in electable positions. This will have the related effect of an increased number of quality female politicians, while also making the remaining spots left for male politicians more competitive. In other words, we expect that parties that use quotas will field a quality list of both male and female candidates, but that they may also have fewer spots left over for less qualified men. This will lead such parties' politicians to be of an overall higher quality.

In the absence of direct previous experience in the EP, the literature consistently views political experience as synonymous with quality candidacy. We thusly expect that when gender 
quotas require parties to bring in new candidates, these candidates should not only be disproportionally women, but should also be more experienced in politics. For this contention and all others, we further expect that quotas will be most effective if they operate alongside placement mandates, which force parties not to squander female candidates in unlikely electoral positions. In other words, our first hypothesis is as follows:

\section{$H_{1}$ : Countries and Parties using gender quotas (alongside placement mandates) will be} associated with MEPs who have higher levels of previous political experience.

However, political experience is not the only important aspect for completing effective work in EP policymaking. Specifically, within the literature on the committee-driven nature of EP legislating, the highly technical and oftentimes apolitical nature of EP work is cited as necessitating the recruitment of MEPs who are more likely to be equipped for the demands of specialized committee work (Daniel 2013, but see also Yordanova 2013). Within the context of gender rules, we expect to see a similar relationship as in $\mathrm{H} 1$, whereby parties that use gender quotas will recruit MEPs that demonstrate higher levels of the sorts of education and professional expertise that are most relevant for EP work. However, what makes an MEP a 'quality' one in this case is not just political experience. More specifically, we anticipate that MEPs from such parties will have more advanced educations and come from employment backgrounds that are more directly compatible with EP work, such as law, international relations, or finance.

$\mathrm{H}_{2}$ : Countries and Parties using gender quotas (alongside placement mandates) will be associated with MEPs who have higher levels of relevant professional expertise for EP work.

To summarize the full argument, we view gender quotas and placement mandates to be useful institutional innovations that can increase women's descriptive representation because they eliminate some traditional barriers to entry for female candidates. Because the candidate pool is increased when more women are encouraged and recruited for office, quotas should raise the bar for the presence of legislators with characteristics more broadly suited to the technical nature of legislative work in the EP. Naturally, a variety of additional variables may also contribute to the 
success of national parties to send politicians to the EP with heightened political experience and relevant professional expertise. We explore such alternate expectations in the following section.

\section{First Cut: Identifying Gendered Differences in MEP Quality}

In order to test a theory about gender quotas and legislator experience, we explore the distribution of experience in the EP in 2014 in two ways. We first explore the previous political experience of both male and female MEPs, before examining the kinds of expertise gained from their professional backgrounds. In terms of political experience, we identify those MEPs who have previously held positions on national party boards, served as members of national parliaments, held local office, or who are returned incumbents from the EP. The measures of relevant professional expertise identify MEPs that have either demonstrated professional experience or educational training, prior to their EP mandate, that is directly related to a particular policy area prescient to the EP's specialized committee system. These categories include MEPs with expertise in agriculture, legal experience, medicine, economics and finance, transportation and telecommunications, education and teaching, international affairs, and journalism. ${ }^{\text {ii }}$

We begin by examining simple associative patterns between all MEPs elected in 2014, their levels of political experience and professional expertise, and their gender. Table 1 displays descriptive information on the percentage of MEPs having each type of experience and expertise across gender and the results of a chi-square test for significant differences between genders. The first subset of columns (1) presents the percentage of women, men, and total MEPs with each category of experience for the entire EP. The second subset (2) presents the percentage of MEPs from member states that use any quota and the third (3) presents the percentage of MEPs in states that use both a quota and a placement mandate. Thus, all percentages are calculated based upon the total number of MEPs. For example, for gendered differences of MEPs that have experience as a former MP, the first subset indicates that $35.37 \%$ of all MEPs have this type experience. However, female MEPs with this type of experience make up only $11.30 \%$ of the EP and male MEPs with such experience represent $24.07 \%$ of the EP. The data from quota countries (subset 2) tells us that only 
$12.77 \%$ of all MEPs come from quota countries and have experience as a national MP; $3.46 \%$ of all MEPs are female former national MPs from quota countries and 9.31\% of the EP are male former MPs from quota countries, and so on.

The columns for the entire population of MEPs, signified through bold and underlined cells, show that differing levels of experience in national party office, past national parliamentary membership and having held a local office are each significantly gendered (in other words, the likelihood of male and female MEPs to display different propensities to appear in each category is significantly different). More specifically, there are significantly more men than women with these types of experience in the EP. On the other hand, gender is not significantly associated with differences in the level of many professional background categories, nor are there many differences in age. This suggests that, on the whole, differences in MEP background that are attributable to gender are mostly limited to political experience.

[Table 1 about here.]

In contrast to the population as a whole, if we only examine patterns among the subsets of MEPs that come from countries with quotas or countries with both quotas and placement mandates, then these patterns change. Information on quotas at the national level (i.e., legislated quotas) is taken from Freidenvall and Dahlerup (2013). The columns show that combining quotas with placement mandates effectively eliminates significant gendered differences for political experience. For example, simple quotas reduce the presence of significant gendered differences in previous local office and national party office, but the addition of placement mandates eliminates significant difference in all forms of political experience. These preliminary results show that while differences in experience across genders do exist in the entire population of MEPs, they do not exist in those countries where both quotas and placement mandates are in place.

\section{Explanations for Women's Representation: Logistic Regression Results and Discussion}

While the associative tests indicate that differences exist between male and female MEPs, and that these differences are mitigated by the presence of quota and placement rules, there are several other 
factors that can also lead to the selection and election of experienced legislators. In order to test the hypothesized relationships across a variety of national and party-level factors, we next model a series of logistic regressions that control for various institutional and cultural differences at the national level. These models take each type of professional and political experience and expertise separately, as their dependent variable. In these models, we use an ordinal measure of quota strength, National Gender Quota, to measure the variance in gender quota laws at the national level. This variable takes three values, 0 in countries where no quotas exists, 1 in countries where simple quotas exist that require no specific placement of women on electoral lists, and 2 for countries where placement mandates exist. ${ }^{\mathrm{iii}}$ In keeping with our hypotheses, the expectation is that higher values of the quota index will correspond with a heightened presence of experience and expertise.

In addition to these national characteristics, the models also include additional indicators that may have bearing on the presence of certain types of experience and expertise and that may also help or hurt women's descriptive representation. We use an updated version of Gallagher's (1991) measure of the disproportionality (based upon calculations from European Election Survey 2009) of the national electoral system (Disproportionality) and the presence of Closed Lists in European elections to identify variations across differing national electoral systems. Districts accounts for the number of electoral districts used for European elections in a given country. ${ }^{\text {iv }}$ Each of these indicators proxies for institutional environments that may impact on the ability of women to be elected. In order to capture the gendered nature of the national political environment, we use three measures that address the general level of gender equality in each EU member state: Women with Degree, which measures the percentage of women per 100 men with an advanced education in each member state, ${ }^{\mathrm{v}}$ Women in National Parliament, which provides the percentage of each national legislature that is female, ${ }^{v i}$ and Gender Equality Index. This index is a composite indicator of general levels of equality across work, money, knowledge, time, power and health provided by the European Institute for Gender Equality . ${ }^{\text {vii }}$ 
We begin by estimating a set of regression models that include country-level data on all MEPs that were initially seated in 2014, excluding replacement MEPs. We then re-estimate the models, using only the subset of MEPs for which party data was available. For each dependent variable, we estimate models using the entire sample of MEPs, just female MEPs, and just male MEPs, in order to also test the effects of quotas across both genders. All logistic models use countryclustered standard errors to account for unobserved heterogeneity at the country level.

\section{Country-Level Quotas and Experience}

Figure 1 presents the results of the logistic regression analysis for a few key areas of professional and political experience for MEPs across the three data groupings (all MEPs, female MEPs, and male MEPs). The first set of plots report the coefficients and 95\% confidence intervals for the effect of national gender quotas and placement mandates on the presence of MEPs with political experience and the second set of plots report the coefficients for relevant professional experience and expertise. $^{\text {viii }}$

[Figure 1 about here.]

Examining the coefficient plots for previous political experience shows mixed results for the effect of national gender quotas across women and men. Here we see the average effect of national gender quotas on the entire population of MEPs is not significantly associated with the likelihood of an MEP demonstrating most types of previous political experience with only national MPs showing a significant and positive relationship. However, testing the relationship between quotas and political experience across the gendered subgroups highlights more nuanced results that are consistent with $\mathrm{H}_{1}$. Most notably, the presence of gender quotas does correlate with the likelihood that women will have national experience (Former MP) prior to entering the EP, as well as the likelihood that men will be have held national party office. This provides evidence in support of $\mathrm{H}_{1}$, which predicted that countries with national gender quotas will have more politically experienced MEPs. The positive and significant effect of the quotas demonstrate the increased likelihood that both male and female MEPs have had previous national experience that may be useful to them in their work in the EP. 
Interestingly, Figure 1 also shows that quota countries are significantly less likely to contain reelected MEPs from the previous term (marked as incumbents), which does not conform to basic assumptions made by $H_{1}$, but the effect appears to be driven by a significant decrease of male incumbents when quotas are used. While the lack of longitudinal information in the structure of our dataset makes it difficult to isolate the mechanism at play specifically, this supports our argument that when countries or parties include gender quotas with placement mandates, competition increases for male MEPs, who may be less assured of winning re-election. In particular, the presence of a national gender quota decreases the predicted probability that an MEP will be a male incumbent by about $11.4 \%$, with placement mandates reducing this by an additional $9.3 \%$. This reduces the male incumbency advantage by nearly half: falling from a $43 \%$ predicted likelihood, when no quotas are in place, to only about $22.5 \%$ when quotas and mandates are used, ceteris paribus. ${ }^{\text {ix }}$ With respect to professional experience, Figure 1 also shows that both men and women from quota countries are significantly more likely to hold qualifications in law and international affairs, and men are more likely to have a $\mathrm{PhD}$ when they come from countries in which national-level gender quotas exist, both of which are attributes that are useful for success in the EP's technical 'working parliament' environment. This provides evidence in support of $H_{2}$, which argues that national-level quotas should increase the number of professionally experienced candidates entering the EP. Of course, the nature of gender equality within each member state might also influence the type of experience MEPs have as professional and educational success might be subject to gendered patterns within society. In order to account for some of these patterns, we included several controls variables for gender equality both in politics and education and an overall general measure. The relationship of these control variables to our experience categories is presented in Tables A1.1 and A1.2 in the appendix. These results show that these measure are, in most cases, not significant predictors of experience. The most notable relationship is between women's education and experience, where the education for women is significantly associated with more women in international affairs, and between women in national parliaments and local politicians which also has a significant and positive relationship. 
[Figure 2 about here.]

In order to further evaluate the substantive effects of quotas and placement mandates described above, Figure 2 presents the predicted probability that female MEPs will have former experience as a national MP (left), expertise in legal professions (center), and expertise in international affairs (right), given the presence of a national quota law in their home country. The results suggest that the power of gender quotas to increase the likelihood of these types of experience comes mostly with the presence of placement mandates, in conjunction with quotas. In fact, the confidence intervals for the Former MPs show that the effect of implementing a placement mandate nearly doubles the effect of a quota. The predicted probability of a woman holding previous experience as an MP increases by half from the baseline, jumping from roughly $9 \%$ to nearly $14 \%$ when simple quotas are instituted. The inclusion of a placement mandate increases this likelihood again, to over $20 \%$. The power of placement mandates is also evident when evaluating experience in international affairs. The right panel of the figure shows that the effect of national quotas is essentially indistinguishable from the absence of quotas with overlapping confidence intervals and average probabilities of about $16 \%$ and $20 \%$. However, placement mandates increase the predicted probably of international experience by an additional $10 \% .^{\mathrm{x}}$

The center column of Figure 2 shows similar results with respect to legal experience, suggesting that the EP appears to benefit from more women with legal experience when countries use both a simple quota and a placement mandate. Here, the baseline probability that a female MEP has legal experience is about $12 \%$, with a quota increasing this probability to about $23 \%$ and placement mandates increasing this to about 39\%. Again, the use of the quota combined with a mandate has a significantly larger effect than the use of simple quotas. In this case, national quotas also have a similar effect on men, increasing the probability they will have legal experience by about $5 \%$ with quotas and $10.5 \%$ with placement mandates from a baseline of about $17.5 \%$. These results provide additional evidence in support of $H_{l}$ with respect to women in the EP, and also highlights how placement mandates are a powerful tool for increasing the level of women with relevant experience 
and expertise in the EP. Overall, these models show fairly substantial effects that support $\mathrm{H}_{1}$ and $\mathrm{H}_{2}$ and suggest that quotas are generally good for increasing the professional expertise among those entering the Parliament and that placement mandates amplify these effects.

In assessing the impact of quotas on the type of MEP expertise, it is also important to note the influence of other factors that may bias for or against the sorts of expertise examined above. Among common electoral system variables, we found significant and independent effects for closed list systems, disproportionally, and the number districts. Regardless of MEP gender, more disproportional systems tended to have more former MPs and local politicians in the EP while states with more districts tended to have less former MPs. This result is unsurprising, given that electoral systems with several, less proportional districts will have many party lists that elect only a single or a few MEPs. Therefore, we would expect to see more homogeneity in the types of candidates that enter the EP through these systems. A more important effect is that of closed list ballots. In the model for political experience, this variable increases the likelihood that men will have political experience while decreasing the likelihood that women will have political experience. Figure 3 shows the coefficients of this variable across genders.

[Figure 3 about here.]

As Figure 3 shows, closed list ballots appear to increase the likelihood that all MEPs will have experience as incumbents and local politicians and decrease the likelihood that women will have been former MPs. This result is especially interesting, given that national gender quotas were shown to increase this type of experience in women. This suggests that closed ballots may attenuate the positive effects of gender quotas on female MEPs. In order to explore this further, Figure 4 presents the effect of national gender quotas on the predicted probability that a female MEP will have served in the national parliament in states with closed list systems and states that have open ballots. As the figure shows, states with closed list ballots in place have, on average, fewer total women in the EP that have served in national parliaments than do states with open list systems.

[Figure 4 about here.] 
However, the overall effect of gender quotas on recruiting MEPs with previous expertise remains positive. In states with closed lists, the use of a simple gender quota increases the predicted probability that women will have experience as a former MP by about $4 \%$ and placement mandates increase this by about another $7 \%$ ( $11.5 \%$ overall). In states with open lists, the marginal effect is slightly larger and the baseline probability is higher. Here, gender quotas increase the likelihood a female MEP will have held national legislative office by about $12 \%$ and placement mandates increase this by about 23 (or an additional 11\%)\%. Overall, this means that women in the EP are less likely to have held national office in closed list systems without quotas (about 5\%) and more likely to have this experience in state with open lists and placement mandates (about 60\%). This demonstrates the positive impact that electoral institutions can have in creating equal access to all political positions for women at the national level. The high correlation of the probability of being a former MP and working in the EP for women in these states is likely the result of having fewer barriers to entry in national politics and is representative of political institutions where cross-institutional careers are possible. We also controlled for several social factors that may influence the overall gender equality present in some societies, across the EU member states, as we consider this to be plausibly endogenous to our causal story. However, we find that these factors do not have consistent effects across our models. For example, the number of women in national parliaments has a positive and significant effect on the likelihood that male MEPs have previous local political experience, but it does not significantly affect the career trajectories of female MEPs. In addition, a country's general level of gender equality decreases the likelihood that male MEPs will have held local elected office (at the 90\% significance level), but it does not have any other effect. Each of these results generally suggests that, as gender equality increases differences associated with gender and political expertise are diminished. ${ }^{\mathrm{xi}}$

\section{Conclusion}

In this paper, we have taken up the important problem of women's descriptive representation in legislative politics and examined the effect of national- and party-level gender quotas and placement 
mandates for the election of quality candidates to the European Parliament. As an international legislature that places a premium on its intra-institutional diversity, the EP represents an important venue for testing the varied electoral systems at play in Europe, with respect to women's representation. In keeping with the broader findings of the literature, we assumed that the presence of gender quotas and placement mandates would not only be useful to the promotion of female candidates to the EP, but that it might also come with an added benefit of improving the quality of all MEPs, through the recruitment of candidates that possess both the previous political experience, as well as professional and educational criteria that might improve the effectiveness of their service in the EP.

In keeping with our expectations, we were able to identify that the association between such institutional choices and representative backgrounds does indeed have a gendered nature to it. More specifically, we found that national quotas can reduce differences between MEP gender and background qualities and that placement mandates are even more effective at erasing differences between male and female MEPs, in terms of their prior experience. This finding suggests that quotas may remove some barriers to entry that women typically face when deciding to run for office, help to promote women with prior political experience to further positions, and also raise the number of politically experienced representatives at the European level. While previous research has also found the important role of placement mandates in the election of women (Jones 2004; Schmidt 2009; Schwindt-Bayer 2009), we show that this is also an effective tool for eliminating differences between men and women's prior experience when entering a legislature.

We were also able to identify some areas in which national rules for female recruitment might actually lead to more experienced and quality representatives, across both genders. Our results indicate that national-level quota and placement rules are positively associated with higher overall number of MEPs with doctoral degrees, as well as those with valuable professional backgrounds in law, economics and finance, and international affairs and diplomacy. National quotas are also correlated with the presence of more MEPs with a former national MP background. This provides 
ample evidence that quotas can impact the overall composition of a legislature and supports our hypotheses that countries and parties that use gender quotas are more likely to have experienced MEPs. It also suggests that the use of quotas co-vary with a heightened number of overall MEPs whose experience is especially suited for the unique needs of the EP.

In sum, our findings reveal that the EP is a suitable laboratory to examine the effect of diverse electoral laws focused on women's numerical and descriptive representation. We also add to the debate on the impact of electoral laws on women's representation by assessing whether or not some laws may also come with the added value (or perhaps detriment) of the quality of representation on offer. Our findings suggest that while gendered differences in political and professional experience do exist in the European Parliament, gender quotas and placement mandates may somewhat abate these differences. Future work can continue to assess the role of party-level rules, as well as to problematize how such institutional innovations may impact on the career trajectories of female politicians across the multiple levels of office available within the EU. In addition, it's worth noting that our research could also be extended to ensuring other kinds of diverse descriptive representation. While gender quotas are perhaps the most pervasive institutional innovation in the EU, other systems - such as reserved seats for ethnic or religious minorities, as well as recruitment mechanisms to boost numbers of other forms of minority representation - can and do exists in various international contexts. While beyond the scope of this particular project, future work should continue to examine how institutional innovations can enhance the quality of representation via the recruitment, selection, and election of additional diverse dimensions.

\footnotetext{
${ }^{\text {i }}$ Of course, it's worth pointing out that the grueling EP calendar, which typically meets two weeks per month in Brussels, one week per month in Strasbourg, and adjourns one week per month to work in home districts, may also be a particular disadvantage for women who attempt to balance private family life with public professional demands.

${ }^{\text {ii }}$ Citation of the data source has been omitted in draft to preserve anonymity. Raw numbers for each category are available in Table S1.4 of the Supplemental Materials.

iii We also test whether party-level gender quotas affect the quality of representation. Results from these models are found in the supplementary appendix. The party level analyses generally support our hypotheses, but due to limitations on data availability at the
} 
party level, we have chosen to focus our main discussion only on national-level rules. Data on gender quotas at the party level is taken in part from Brodolini et al. (2014) and (citation omitted). In these models, we are also able to control for ideology at the party level using a series of party family variables from the 2014 Chapel Hill Expert Survey (Polk et al. 2017)

${ }^{\text {iv }}$ Contextual data for European and National Elections comes from Egmond, et. al (2013) where it was calculated based on Gallagher (1991). Gallagher's index for Croatia was calculated by the authors based on the 2011 national election with data from the European Election Database, available here: http://www.nsd.uib.no/european_election_database/country/croatia/

v These data are taken from the Eurostat Database measure "Tertiary education graduates" for 2012 and is available at http://ec.europa.eu/eurostat/web/equality/data/database.

vi This a measure of women in national legislatures in May 2014 from the database of the Inter-parliamentary Union.

vii We use the data from 2012 and the Index ranges from 0 to 100 with 100 being the most gender equality. The data can be accessed here https://data.europa.eu/euodp/data/dataset/gender-equality-index and it was downloaded on 11/19/2018.

viii Tables A1.1 and A1.2 in the appendix report the complete logistic regression results for all of these plots. The supplementary materials also include models for additional categories of professional experience.

${ }^{\text {ix }}$ Plots of predicted probabilities for male MEPs are available in figure A1.1 the supplementary materials.

${ }^{x}$ All predicted probabilities reported in the paper are calculated holding all controls at their mean or median value and using the clarify function in Stata (Tomz, Wittenberg, and King 2003). Coefficient plots were constructed using the Coef package (Jann 2014).

xi These results are also robust to an array of alternative measures for societal gender equality, as discussed in the supplementary appendices. 


\section{References}

Aldrich, Andrea S. 2018a. "National Political Parties and Career Paths to the European Parliament." JCMS: The Journal of Common Market Studies 56(6): 1283-1304.

Aldrich, Andrea S. 2018b. "Party Organization and Gender in European Elections." Party Politics: 135406881880663.

Allen, Peter, David Cutts, and Rosie Campbell. 2016. "Measuring the Quality of Politicians Elected by Gender Quotas - Are They Any Different?” Political Studies 64(1): 143-63.

Anzia, Sarah F., and Christopher R. Berry. 2011. “The Jackie (and Jill) Robinson Effect: Why Do Congresswomen Outperform Congressmen?” American Journal of Political Science 55(3): $478-493$.

Baltrunaite, Audinga, Piera Bello, Alessandra Casarico, and Paola Profeta. 2014. "Gender Quotas and the Quality of Politicians.” Journal of Public Economics 118: 62-74.

Barnes, Tiffany D., and Stephanie M. Burchard. 2013. ““Engendering’ Politics: The Impact of Descriptive Representation on Women's Political Engagement in Sub-Saharan Africa.” Comparative Political Studies 46(7): 767-790.

Bernauer, Julian, Nathalie Giger, and Jan Rosset. 2015. "Mind the Gap: Do Proportional Electoral Systems Foster a More Equal Representation of Women and Men, Poor and Rich?” International Political Science Review 36(1): 78-98.

Campbell, David E., and Christina Wolbrecht. 2006. "See Jane Run: Women Politicians as Role Models for Adolescents." The Journal of Politics 68(2): 233-47. 
Caul, Miki. 2001. "Political Parties and the Adoption of Candidate Gender Quotas: A Cross-National Analysis.” Journal of Politics 63(4): 1214-1229.

Chiva, Cristina. 2014. "Gender, European Integration and Candidate Recruitment: The European Parliament Elections in the New EU Member States.” Parliamentary Affairs 67(2): 458-94.

Dahlerup, Drude, and Lenita Freidenvall. 2010. "Judging Gender Quotas: Predictions and Results.” Policy \& Politics 38(3): 407-25.

Daniel, William T. 2013. "When the Agent Knows Better than the Principal: The Effect of Education and Seniority on European Parliament Rapporteur Assignment." JCMS: Journal of Common Market Studies 51(5): 832-48.

2015. Career Behaviour and the European Parliament: All Roads Lead Through Brussels? Oxford: Oxford University Press.

Daniel, William T., and Shawna K. Metzger. 2018. "Within or between Jobs? Determinants of Membership Volatility in the European Parliament, 1979-2014.” The Journal of Legislative Studies 24(1): 90-108.

Davidson-Schmich, Louise K. 2016. Gender Quotas and Democratic Participation: Recruiting Candidates for Elective Offices in Germany. University of Michigan Press.

Egmond, Marcel van et al. 2013. "European Parliament Election Study 2009, Voter Study.” GESIS Data Archive ZA5055 Data file Version 1.1.0 DOI: 10.4232/1.11760.

Fortin-Rittberger, Jessica, and Berthold Rittberger. 2014. "Do Electoral Rules Matter? Explaining National Differences in Women's Representation in the European Parliament.” European Union Politics 15(4): 496-520. 
_. 2015. 'Nominating Women for Europe: Exploring the Role of Political Parties' Recruitment Procedures for European Parliament Elections.” European Journal of Political Research 54(4): 767-83.

Fox, Richard L, and Jennifer L Lawless. 2004. "Entering the Arena? Gender and the Decision to Run for Office.” American Journal of Political Science 48(2): 264-280.

Freidenvall, Lenita, and Drude Dahlerup. 2013. Electoral Gender Quota Systems and Their Implementation in Europe (Updated 2013) IPOL\-FEMM\-NT(2013)493011_EN.

Fridkin, Kim L., and Patrick J. Kenney. 2014. “How the Gender of U.S. Senators Influences People’s Understanding and Engagement in Politics.” The Journal of Politics 76(4): 1017-31.

Gallagher, Michael. 1991. "Proportionality, Disproportionality and Electoral Systems.” Electoral studies 10(1): 33-51.

Holzer, Harry J., and David Neumark. 2000. “What Does Affirmative Action Action Do?” Industrial \& Labor Relations Review; Ithaca 53(2): 240-71.

Huddy, Leonie, and Nayda Terkildsen. 1993. "Gender Stereotypes and the Perception of Male and Female Candidates.” American Journal of Political Science 37(1): 119-47.

Jann, Ben. 2014. "Plotting Regression Coefficients and Other Estimates." The Stata Journal 14(4): 708-37.

Jones, Mark P. 2004. "Quota Legislation and the Election of Women: Learning from the Costa Rican Experience." The Journal of Politics 66(4): 1203-23.

Kanthak, Kristin, and Jonathan Woon. 2015. “Women Don’t Run? Election Aversion and Candidate Entry.” American Journal of Political Science 59(3): 595-612. 
Krook, Mona Lena. 2010a. Quotas for Women in Politics Gender and Candidate Selection Reform Worldwide. Oxford: Oxford University Press.

. 2010b. "Why Are Fewer Women than Men Elected? Gender and the Dynamics of Candidate Selection.” Political Studies Review 8(2): 155-68.

Krook, Mona Lena, and Pippa Norris. 2014. "Beyond Quotas: Strategies to Promote Gender Equality in Elected Office." Political Studies 62(1): 2-20.

Lovenduski, Joni. 2005. Feminizing Politics. Polity.

Luhiste, Maarja. 2015. "Party Gatekeepers' Support for Viable Female Candidacy in PR-List Systems." Politics \&amp; Gender 11(1): 89-116.

Lühiste, Maarja, and Meryl Kenny. 2016. “Pathways to Power: Women's Representation in the 2014 European Parliament Elections.” European Journal of Political Research 55(3): 626-41.

Mansbridge, Jane. 1999. "Should Blacks Represent Blacks and Women Represent Women? A Contingent 'Yes."' The Journal of Politics 61(3): 628-57.

Matland, Richard. 2006. "Electoral Quotas: Frequency and Effectiveness.” In Women, Quotas and Politics, ed. Drude Dahlerup. New York: Routledge, 275-292.

Meserve, Stephen A., Daniel Pemstein, and William T. Bernhard. 2018. “Gender, Incumbency and Party List Nominations.” British Journal of Political Science: 1-15.

Murray, Rainbow. 2010. “Second Among Unequals? A Study of Whether France's 'Quota Women' Are Up to the Job.” Politics \&amp; Gender 6(1): 93-118. 
Niederle, Muriel, Carmit Segal, and Lise Vesterlund. 2013. "How Costly Is Diversity? Affirmative Action in Light of Gender Differences in Competitiveness.” Management Science 59(1): 116.

O’brien, Diana Z., and Johanna Rickne. 2016. “Gender Quotas and Women’s Political Leadership.” American Political Science Review 110(1): 112-26.

Pemstein, Daniel, Stephen A Meserve, and William T Bernhard. 2015. "Brussels Bound Policy Experience and Candidate Selection in European Elections.” Comparative Political Studies 48(11): 1421-1453.

Prpic, Martina, and Samy Chahri. 2017. Womean in Parliaments: National Parliaments with a Higher Proportio of Women Members than the EP. Brussels: European Parliament. http://www.europarl.europa.eu/EPRS/EPRS-at-a-glance-599314-Women-inparliaments\%20Update_FINAL.pdf (August 1, 2017).

Pruysers, Scott, William P. Cross, Anika Gauja, and Gideon Rahat. 2017. “Candidate Selection Rules and Democratic Outcomes: The Impact of Parties on Women's Representation.” In Organizing Political Parties Representation, Participation, and Power, eds. Susan E Scarrow, Paul D. Webb, and Thomas Poguntke. Oxford: Oxford University Press.

Ringe, Nils. 2010. Who Decides, and How?: Preferences, Uncertainty, and Policy Choice in the European Parliament. Oxford University Press.

Schmidt, Gregory D. 2009. "The Election of Women in List PR Systems: Testing the Conventional Wisdom." Electoral studies 28(2): 190-203.

Schwindt-Bayer, Leslie A. 2009. "Making Quotas Work: The Effect of Gender Quota Laws On the Election of Women." Legislative Studies Quarterly 34(1): 5-28. 
Schwindt-Bayer, Leslie A. 2011. "Women Who Win: Social Backgrounds, Paths to Power, and Political Ambition in Latin American Legislatures.” Politics \& Gender 7(1): 1-33.

Teele, Dawn Langan, Joshua Kalla, and Frances Rosenbluth. 2018. "The Ties That Double Bind: Social Roles and Women's Underrepresentation in Politics.” The American Political Science Review; Washington 112(3): 525-41.

Valdini, Melody Ellis. 2012. “A Deterrent to Diversity: The Conditional Effect of Electoral Rules on the Nomination of Women Candidates." Electoral Studies 31(4): 740-749.

Volden, Craig, and Alan Wiseman. 2014. Legislative Effectiveness in the United States Congress. Cambridge: Cambridge Univeristy Press.

Weeks, Ana Catalano, and Lisa Baldez. 2015. “Quotas and Qualifications: The Impact of Gender Quota Laws on the Qualifications of Legislators in the Italian Parliament.” European Political Science Review 7(1): 119-44.

Wolbrecht, Christina, and David E. Campbell. 2007. "Leading by Example: Female Members of Parliament as Political Role Models.” American Journal of Political Science 51(4): 921-39.

Xydias, Christina. 2016. “Discrepancies in Women's Presence between European National Legislatures and the European Parliament: A Contextual Explanation.” Political Research Quarterly 69(4): 800-812.

Yordanova, Nikoleta. 2013. Organising the European Parliament: The Role of the Committees and Their Legislative Influence. ECPR Press.

Yoshinaka, Antoine, Gail McElroy, and Shaun Bowler. 2010. "The Appointment of Rapporteurs in the European Parliament." Legislative Studies Quarterly 35(4): 457-486. 


\section{Figure 1: Experience and National Gender Quotas}

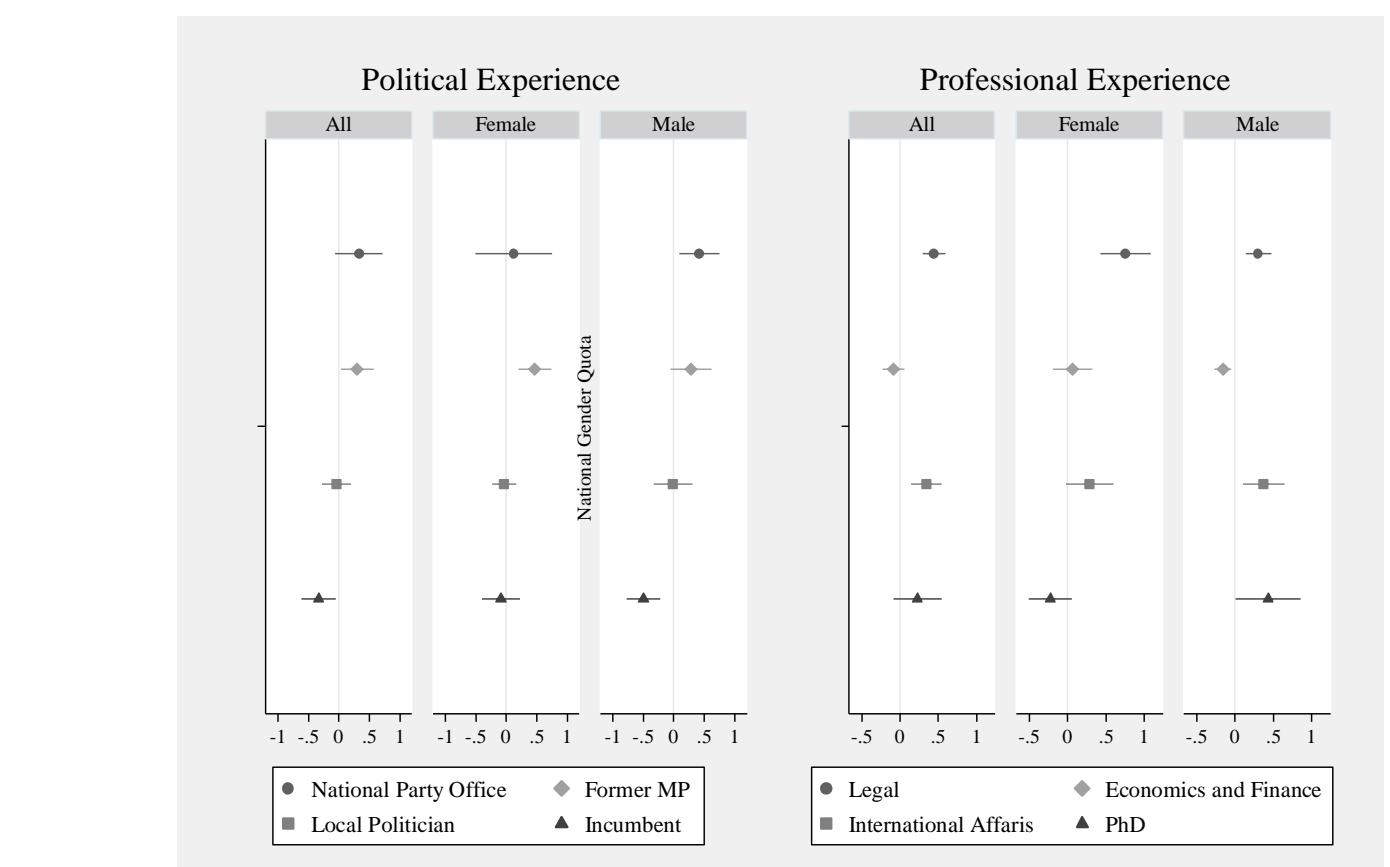

The plots above display the coefficients and 95\% confidence intervals of National Gender Quota for each dependent variable measuring experience.

Figure 2: Predicted Probabilities of Female MEPs and National Gender Quotas

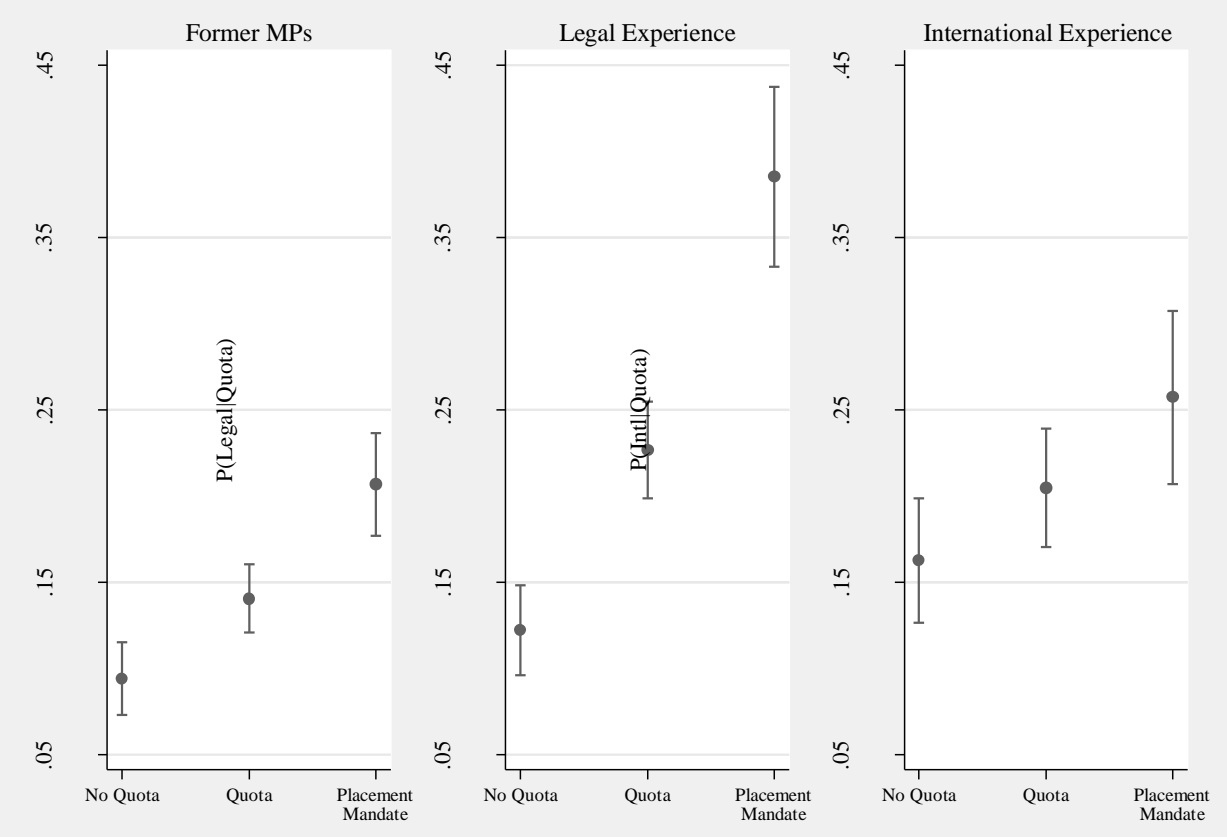

The plots above display the mean predicted probability and 95\% confidence intervals for each dependent variable measuring given the level of quota. All remaining variables in model set to their mean with the exception of closed list which is set at its median. 
Figure 3: Political Experience and Closed Ballot Effects

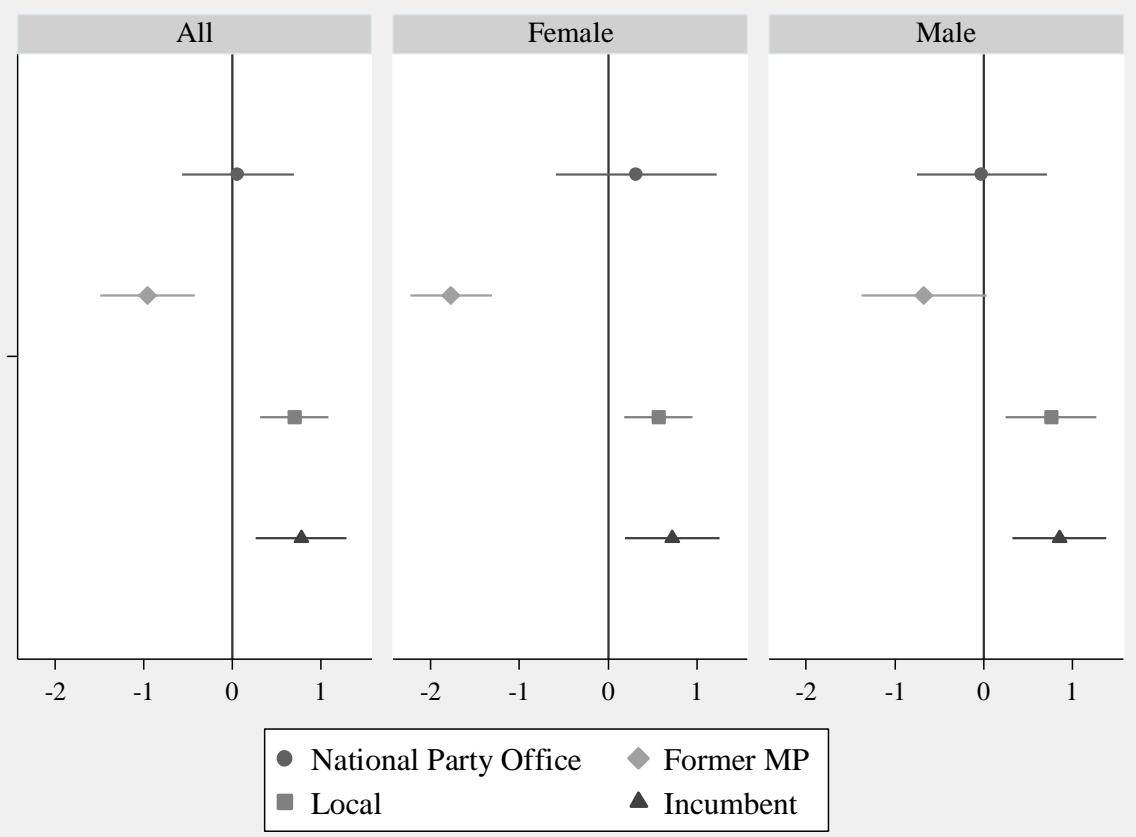

Figure 4: Ballot Effects and Female MEPs as Former MPs
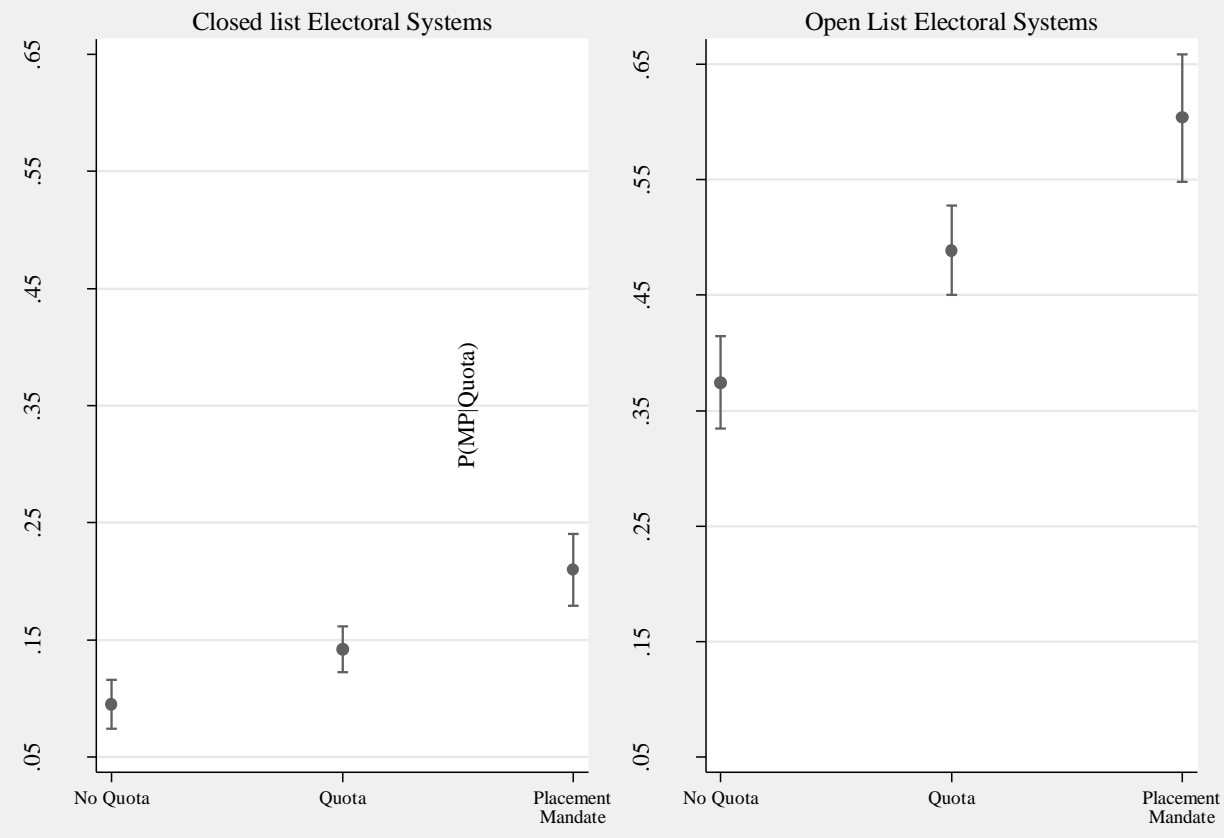
Table 1: Gender and Experience in the European Parliament

\begin{tabular}{|c|c|c|c|c|c|c|c|c|c|c|c|c|c|}
\hline & & \multicolumn{4}{|c|}{ (1) Entire Population ${ }^{1}$} & \multicolumn{4}{|c|}{ (2) Quota Countries } & \multicolumn{4}{|c|}{ (3) Placement Countries } \\
\hline & & Women & Men & Both & $p$ & Women & Men & Both & $p$ & Women & Men & Both & $p$ \\
\hline & $\%$ of Full EP & 36.70 & 63.30 & 100.00 & & 11.57 & 21.68 & 33.24 & & 8.91 & 13.70 & 22.61 & \\
\hline Political & National Party Office & $\underline{5.32}$ & $\underline{14.49}$ & $\underline{19.81}$ & $\underline{0.01}$ & $\underline{1.86}$ & 5.72 & $\underline{7.58}$ & $\underline{0.07}$ & 1.86 & 4.52 & 5.98 & 0.18 \\
\hline \multirow[t]{3}{*}{ Experience } & Former MP & $\underline{11.30}$ & $\underline{24.07}$ & $\underline{35.37}$ & $\overline{0.05}$ & $\underline{3.46}$ & $\overline{9.31}$ & $\overline{12.77}$ & $\underline{0.04}$ & 1.86 & 4.26 & 6.12 & 0.15 \\
\hline & Former Local Politician & $\underline{17.31}$ & $\underline{25.30}$ & $\underline{42.61}$ & $\overline{0.05}$ & 6.13 & 9.72 & $\overline{15.85}$ & 0.22 & 5.06 & 7.99 & 13.05 & 0.84 \\
\hline & Incumbent & 18.09 & 29.65 & $\overline{47.74}$ & $\overline{0.52}$ & 5.45 & 8.64 & 14.10 & 0.23 & 4.52 & 6.12 & 10.77 & 0.33 \\
\hline Professional. & Agriculture $^{2}$ & 1.61 & 4.56 & 6.17 & 0.13 & 0.67 & 1.48 & 2.15 & 0.75 & 0.67 & 0.67 & 1.34 & 0.48 \\
\hline \multirow[t]{8}{*}{ Experience } & Legal & 7.25 & 15.17 & 22.42 & 0.19 & 3.36 & 6.31 & 9.66 & 0.96 & 3.09 & 4.97 & 8.05 & 0.83 \\
\hline & Medical & 2.01 & 2.15 & 4.16 & 0.17 & 0.40 & 0.81 & 1.21 & 0.92 & 0.40 & 0.67 & 1.07 & 0.91 \\
\hline & Economic and Finance & 8.99 & 17.58 & 8.99 & 0.34 & 3.09 & 5.37 & 8.46 & 0.76 & 2.01 & 3.36 & 5.37 & 0.78 \\
\hline & $\begin{array}{l}\text { Transportation and } \\
\text { Telecom }\end{array}$ & 2.68 & 4.03 & 6.71 & 0.61 & 0.40 & 0.67 & 1.07 & 0.88 & $\underline{0.27}$ & $\underline{0.00}$ & $\underline{0.27}$ & $\underline{0.08}$ \\
\hline & Teacher & $\underline{5.64}$ & $\underline{14.50}$ & $\underline{20.13}$ & $\underline{0.01}$ & 2.28 & 6.17 & 8.46 & 0.13 & $\underline{1.48}$ & $\underline{4.03}$ & $\underline{5.50}$ & $\underline{0.06}$ \\
\hline & International & $\overline{8.59}$ & $\overline{17.05}$ & $\overline{25.64}$ & $\overline{0.30}$ & 2.95 & 6.31 & 9.26 & 0.53 & $\overline{2.15}$ & $\overline{3.36}$ & $\overline{5.50}$ & $\overline{0.95}$ \\
\hline & $\mathrm{PhD}$ & $\underline{5.91}$ & $\underline{13.42}$ & $\underline{19.33}$ & $\underline{0.09}$ & $\underline{1.34}$ & $\underline{5.91}$ & $\underline{7.25}$ & $\underline{0.00}$ & $\underline{0.94}$ & $\underline{3.09}$ & $\underline{4.03}$ & $\underline{0.03}$ \\
\hline & Journalist & $\overline{3.76}$ & 6.98 & $\overline{10.74}$ & $\overline{0.75}$ & $\overline{0.94}$ & $\overline{2.55}$ & $\overline{3.49}$ & $\overline{0.37}$ & $\overline{0.27}$ & $\overline{1.74}$ & $\underline{\underline{2.01}}$ & $\overline{0.03}$ \\
\hline \multirow[t]{7}{*}{ Age } & Age $\geq 20 \&<30$ & $\underline{0.80}$ & $\underline{1.33}$ & $\underline{2.13}$ & 0.09 & $\underline{0.00}$ & $\underline{0.13}$ & $\underline{0.13}$ & 0.46 & 0.00 & 0.13 & 0.13 & 0.42 \\
\hline & Age $\geq 30 \&<40$ & $\overline{5.85}$ & $\overline{7.45}$ & $\overline{13.30}$ & $\underline{0.10}$ & $\underline{1.60}$ & $\underline{1.99}$ & $\underline{3.59}$ & 0.03 & 1.46 & 1.60 & 3.06 & 0.38 \\
\hline & Age $\geq 40 \&<50$ & $\overline{9.57}$ & $\overline{17.15}$ & $\overline{26.73}$ & $\overline{0.76}$ & $\underline{3.19}$ & $\underline{4.52}$ & $\underline{7.71}$ & 0.23 & 2.13 & 3.06 & 5.19 & 0.81 \\
\hline & Age $\geq 50 \&<60$ & 13.56 & 20.61 & 34.18 & 0.22 & 3.99 & $\underline{8.51}$ & $\underline{12.50}$ & 0.46 & 3.06 & 5.19 & 8.24 & 0.64 \\
\hline & Age $\geq 60 \&<70$ & $\underline{5.98}$ & $\underline{13.70}$ & $\underline{19.68}$ & $\underline{0.08}$ & $\underline{2.39}$ & $\underline{4.79}$ & $\underline{7.18}$ & 0.80 & 1.86 & 2.79 & 4.65 & 0.94 \\
\hline & Age $\geq 70 \&<80$ & $\overline{0.93}$ & 2.79 & $\overline{3.72}$ & $\overline{0.19}$ & $\overline{0.40}$ & $\overline{1.46}$ & $\overline{1.86}$ & 0.28 & 0.40 & 0.80 & 1.20 & 0.70 \\
\hline & Age $\geq 80$ & 0.00 & 0.27 & 0.27 & 0.28 & $\underline{0.00}$ & $\underline{0.27}$ & $\underline{0.27}$ & 0.30 & 0.00 & 0.13 & 0.13 & 0.42 \\
\hline
\end{tabular}

\footnotetext{
${ }^{1}$ The subset of columns provides the percentage of women, men, and all MEPs that hold each category of experience, among all MEPs initially seated in 2014 (1), the percentage of all women, men, and MEPs that hold each category of experience and that also come from Quota countries (2), and the percentage of all women, men, and MEPs that hold each category of experience and that also come from placement countries (3), respectively. Each $p$ column provides the $\mathrm{p}$ value of a $\mathrm{X}^{2}$ test of association between genders for each category of experience, in each subgroup. Bold and underlined values indicate $\mathrm{X}^{2}$ values with significance $\geq 90 \%$.

${ }^{2}$ For all professional categories, $\mathrm{N}=745$ and thus the percentage calculations for these experience categories use 745 as the denominator. Categories are not necessarily mutually exclusive.
} 
'United in Diversity?' 33

\section{Appendix}

Table A1.1: Political Experience and National Gender Quotas

\begin{tabular}{|c|c|c|c|c|c|c|c|c|c|c|c|c|}
\hline \multirow[t]{2}{*}{ VARIABLES } & \multicolumn{3}{|c|}{$\begin{array}{c}\text { (1) } \\
\text { National Party Office }\end{array}$} & \multicolumn{3}{|c|}{$\begin{array}{c}(2) \\
\text { Former MPs }\end{array}$} & \multicolumn{3}{|c|}{$\begin{array}{c}\text { (3) } \\
\text { Local Politicians }\end{array}$} & \multicolumn{3}{|c|}{$\begin{array}{c}\text { (4) } \\
\text { Incumbents }\end{array}$} \\
\hline & All & Female & Male & All & Female & Male & All & Female & Male & All & Female & Male \\
\hline National Gender Quota & $\begin{array}{l}0.328^{*} \\
(0.196)\end{array}$ & $\begin{array}{l}0.123 \\
(0319)\end{array}$ & $\begin{array}{l}0.418 * * \\
(0168)\end{array}$ & $\begin{array}{l}0.298^{* *} \\
(0138)\end{array}$ & $\begin{array}{l}0.467 * * * \\
(0.136)\end{array}$ & $\begin{array}{l}0.282 * \\
(0.171)\end{array}$ & \begin{tabular}{|l|}
-0.036 \\
$(0.121)$
\end{tabular} & $\begin{array}{l}-0.035 \\
(0.102)\end{array}$ & $\begin{array}{l}-0.013 \\
(0.161)\end{array}$ & $\begin{array}{l}-0.332 * * \\
(0.142)\end{array}$ & $\begin{array}{l}-0.087 \\
(0.159)\end{array}$ & $\begin{array}{l}-0.497 * * * \\
(0.143)\end{array}$ \\
\hline Closed List & $\begin{array}{l}0.059 \\
(0.321)\end{array}$ & $\begin{array}{l}0.320 \\
(0.461)\end{array}$ & $\begin{array}{l}-0.024 \\
(0.373)\end{array}$ & $\begin{array}{l}-0.957 * * * \\
(0.272)\end{array}$ & $\begin{array}{l}-1.769 * * * \\
(0.235)\end{array}$ & $\begin{array}{l}-0.674 * \\
(0.361)\end{array}$ & $\begin{array}{l}0.698^{* * * *} \\
(0.197)\end{array}$ & $\begin{array}{l}0.567 * * * \\
(0.197)\end{array}$ & $\begin{array}{l}0.757 * * * \\
(0.262)\end{array}$ & $\begin{array}{l}0.773 * * * \\
(0.262)\end{array}$ & $\begin{array}{l}0.719 * * * \\
(0.272)\end{array}$ & $\begin{array}{l}0.851^{* * * *} \\
(0.269)\end{array}$ \\
\hline Disproportionality & $\begin{array}{l}0.089^{*} \\
(0.049)\end{array}$ & $\begin{array}{l}0.127 \\
(0.091)\end{array}$ & $\begin{array}{l}0.085 \\
(0.054)\end{array}$ & $\begin{array}{l}0.028 \\
(0.057)\end{array}$ & $\begin{array}{l}0.076 \\
(0.048)\end{array}$ & $\begin{array}{l}0.000 \\
(0.080)\end{array}$ & $\begin{array}{l}0.134 * * * \\
(0.047)\end{array}$ & $\begin{array}{l}0.083 \\
(0.052)\end{array}$ & $\begin{array}{l}0.158 * * * \\
(0.058)\end{array}$ & $\begin{array}{l}0.025 \\
(0.052)\end{array}$ & $\begin{array}{l}-0.033 \\
(0.089)\end{array}$ & $\begin{array}{l}0.055 \\
(0.053)\end{array}$ \\
\hline \# of Districts & $\begin{array}{l}-0.074 * * \\
(0.034)\end{array}$ & $\begin{array}{l}-0.074 \\
(0.063)\end{array}$ & $\begin{array}{l}-0.086^{* * * *} \\
(0.030)\end{array}$ & $\begin{array}{l}-0.092 * * * \\
(0.029)\end{array}$ & $\begin{array}{l}-0.158 * * * \\
(0.038)\end{array}$ & $\begin{array}{l}-0.073^{* *} \\
(0.032)\end{array}$ & $\begin{array}{l}0.043 * \\
(0.024)\end{array}$ & $\begin{array}{l}0.018 \\
(0.020)\end{array}$ & $\begin{array}{l}0.058 \\
(0.036)\end{array}$ & $\begin{array}{l}-0.036 \\
(0.024)\end{array}$ & $\begin{array}{l}-0.102 * * * \\
(0.035)\end{array}$ & $\begin{array}{l}-0.006 \\
(0.022)\end{array}$ \\
\hline$\%$ Women in Natl Parliament & $\begin{array}{l}-0.005 \\
(0.021)\end{array}$ & $\begin{array}{l}0.013 \\
(0.037)\end{array}$ & $\begin{array}{l}-0.008 \\
(0.024)\end{array}$ & $\begin{array}{l}-0.027 \\
(0.020)\end{array}$ & $\begin{array}{l}0.000 \\
(0.019)\end{array}$ & $\begin{array}{l}-0.042 \\
(0.028)\end{array}$ & $\begin{array}{l}0.087 * * * \\
(0.021)\end{array}$ & $\begin{array}{l}0.064 * * * \\
(0.017)\end{array}$ & $\begin{array}{l}0.100 * * * \\
(0.031)\end{array}$ & $\begin{array}{l}0.002 \\
(0.019)\end{array}$ & $\begin{array}{l}-0.040 \\
(0.026)\end{array}$ & $\begin{array}{l}0.021 \\
(0.018)\end{array}$ \\
\hline$\%$ Women with degree & $\begin{array}{l}0.005 \\
(0.007)\end{array}$ & $\begin{array}{l}-0.007 \\
(0.010)\end{array}$ & $\begin{array}{l}0.010 \\
(0.009)\end{array}$ & $\begin{array}{l}0.032 \text { *** } \\
(0.007)\end{array}$ & $\begin{array}{l}0.032 * * * \\
(0.009)\end{array}$ & $\begin{array}{l}0.032 * * * \\
(0.009)\end{array}$ & $\begin{array}{l}-0.001 \\
(0.005)\end{array}$ & $\begin{array}{l}0.001 \\
(0.006)\end{array}$ & $\begin{array}{l}-0.003 \\
(0.006)\end{array}$ & $\begin{array}{l}0.006 \\
(0.006)\end{array}$ & $\begin{array}{l}0.006 \\
(0.007)\end{array}$ & $\begin{array}{l}0.007 \\
(0.006)\end{array}$ \\
\hline Gender Equality Index & $\begin{array}{l}-0.034 \\
(0.021)\end{array}$ & $\begin{array}{l}-0.043 \\
(0.037)\end{array}$ & $\begin{array}{l}-0.027 \\
(0.020)\end{array}$ & $\begin{array}{l}0.010 \\
(0.025)\end{array}$ & $\begin{array}{l}-0.031 \\
(0.029)\end{array}$ & $\begin{array}{l}0.031 \\
(0.033)\end{array}$ & $\begin{array}{l}-0.036^{*} \\
(0.019)\end{array}$ & $\begin{array}{l}-0.030 \\
(0.024)\end{array}$ & $\begin{array}{l}-0.047^{*} \\
(0.027)\end{array}$ & $\begin{array}{l}0.033 \\
(0.022)\end{array}$ & $\begin{array}{l}0.039 \\
(0.030)\end{array}$ & $\begin{array}{l}0.033 \\
(0.021)\end{array}$ \\
\hline Age & $\begin{array}{l}0.024 * * \\
(0.011)\end{array}$ & $\begin{array}{l}0.041^{*} \\
(0.023)\end{array}$ & $\begin{array}{l}0.015 \\
(0.013)\end{array}$ & $\begin{array}{l}0.044 * * * * \\
(0.008)\end{array}$ & $\begin{array}{l}0.054 * * * \\
(0.015)\end{array}$ & $\begin{array}{l}0.042 * * * \\
(0.011)\end{array}$ & $\begin{array}{l}0.022 * * * \\
(0.008)\end{array}$ & $\begin{array}{l}0.047 * * * \\
(0.012)\end{array}$ & $\begin{array}{l}0.011 \\
(0.010)\end{array}$ & $\begin{array}{l}0.053 * * * \\
(0.006)\end{array}$ & $\begin{array}{l}0.057 \text { *** } \\
(0.012)\end{array}$ & $\begin{array}{l}0.055^{* * *} \\
(0.009)\end{array}$ \\
\hline Constant & $\begin{array}{l}-1.581 \\
(2.034)\end{array}$ & $\begin{array}{l}-1.257 \\
(2.956)\end{array}$ & $\begin{array}{l}-1.990 \\
(2.450)\end{array}$ & $\begin{array}{l}-7.120 \text { **** } \\
(2.260)\end{array}$ & $\begin{array}{l}-5.764 * * \\
(2.833)\end{array}$ & $\begin{array}{l}-7.867 * * * \\
(2.672)\end{array}$ & $\begin{array}{l}-2.829 * * \\
(1.225)\end{array}$ & $\begin{array}{l}-3.365^{*} \\
(1.903)\end{array}$ & $\begin{array}{l}-2.082 \\
(1.784)\end{array}$ & $\begin{array}{l}-5.998 * * * \\
(1.864)\end{array}$ & $\begin{array}{l}-4.771 * * \\
(2.079)\end{array}$ & $\begin{array}{l}-7.119 * * * \\
(2.056)\end{array}$ \\
\hline Observations & 752 & 276 & 476 & 752 & 276 & 476 & 751 & 275 & 476 & 752 & 276 & 476 \\
\hline Pseudo $\mathrm{R}^{2}$ & 0.0469 & 0.0517 & 0.0532 & 0.172 & 0.254 & 0.145 & 0.0657 & 0.0695 & 0.0747 & 0.0831 & 0.0880 & 0.0976 \\
\hline Wald $X^{2}(12)$ & 34.13 & 11.55 & 33.04 & 85.97 & 181.3 & 47.97 & 63.20 & 35.46 & 34.06 & 130.5 & 41.55 & 89.66 \\
\hline Prob $>X^{2}$ & 0.000 & 0.172 & 0.000 & 0.000 & 0.000 & 0.000 & 0.000 & 0.000 & 0.000 & 0.000 & 0.000 & 0.000 \\
\hline
\end{tabular}
$* * * \mathrm{p}<0.01, * * \mathrm{p}<0.05, * \mathrm{p}<0.1$

Table A1.2: Professional Experience and National Gender Quotas

\begin{tabular}{|c|c|c|c|c|c|c|c|c|c|c|c|c|}
\hline \multirow[b]{2}{*}{ VARIABLES } & \multicolumn{3}{|c|}{$\begin{array}{c}(1) \\
\text { Legal }\end{array}$} & \multicolumn{3}{|c|}{$\begin{array}{c}\text { (2) } \\
\text { Economics and Finance }\end{array}$} & \multicolumn{3}{|c|}{$\begin{array}{c}\text { (3) } \\
\text { International Affairs } \\
\end{array}$} & \multicolumn{3}{|c|}{$\begin{array}{l}(4) \\
\mathrm{PhD}\end{array}$} \\
\hline & All & Female & Male & All & Female & Male & All & Female & Male & All & Female & Male \\
\hline National Gender Quota & $\begin{array}{c}0.439 * * * \\
(0.075)\end{array}$ & $\begin{array}{l}0.757 * * * \\
(0.167)\end{array}$ & $\begin{array}{l}0.305^{* * *} * \\
(0.085)\end{array}$ & $\begin{array}{l}-0.088 \\
(0.072)\end{array}$ & $\begin{array}{c}0.063 \\
(0.131)\end{array}$ & $\begin{array}{c}-0.159 * * * \\
(0.056)\end{array}$ & $\begin{array}{c}0.341^{* * * *} \\
(0.103)\end{array}$ & $\begin{array}{l}0.288^{*} \\
(0.159)\end{array}$ & $\begin{array}{c}0.375 * * * \\
(0.137)\end{array}$ & $\begin{array}{c}0.226 \\
(0.160)\end{array}$ & $\begin{array}{l}-0.223 \\
(0.144)\end{array}$ & $\begin{array}{c}0.433 * * \\
(0.216)\end{array}$ \\
\hline Closed List & $\begin{array}{c}0.189 \\
(0.196)\end{array}$ & $\begin{array}{l}-0.003 \\
(0.324)\end{array}$ & $\begin{array}{c}0.309 \\
(0.241)\end{array}$ & $\begin{array}{c}0.230 \\
(0.161)\end{array}$ & $\begin{array}{l}-0.284 \\
(0.287)\end{array}$ & $\begin{array}{l}0.464 * * \\
(0.183)\end{array}$ & $\begin{array}{c}-0.616^{* *} \\
(0.245)\end{array}$ & $\begin{array}{l}-0.434 \\
(0.356)\end{array}$ & $\begin{array}{c}-0.757 * * * * \\
(0.289)\end{array}$ & $\begin{array}{l}-0.040 \\
(0.292)\end{array}$ & $\begin{array}{c}0.093 \\
(0.415)\end{array}$ & $\begin{array}{l}-0.077 \\
(0.339)\end{array}$ \\
\hline Disproportionality & $\begin{array}{l}-0.040 \\
(0.033)\end{array}$ & $\begin{array}{c}-0.153^{* *} \\
(0.070)\end{array}$ & $\begin{array}{c}0.013 \\
(0.051)\end{array}$ & $\begin{array}{c}-0.014 \\
(0.029)\end{array}$ & $\begin{array}{c}0.039 \\
(0.047)\end{array}$ & $\begin{array}{c}-0.040 \\
(0.036)\end{array}$ & $\begin{array}{c}0.020 \\
(0.056)\end{array}$ & $\begin{array}{c}0.060 \\
(0.071)\end{array}$ & $\begin{array}{c}0.001 \\
(0.059)\end{array}$ & $\begin{array}{l}-0.100 * \\
(0.053)\end{array}$ & $\begin{array}{l}-0.043 \\
(0.089)\end{array}$ & $\begin{array}{c}-0.125 * * \\
(0.060)\end{array}$ \\
\hline \# of Districts & $\begin{array}{l}-0.021 \\
(0.023)\end{array}$ & $\begin{array}{l}-0.050 \\
(0.050)\end{array}$ & $\begin{array}{l}-0.006 \\
(0.030)\end{array}$ & $\begin{array}{l}-0.001 \\
(0.021)\end{array}$ & $\begin{array}{c}0.018 \\
(0.043)\end{array}$ & $\begin{array}{l}-0.004 \\
(0.019)\end{array}$ & $\begin{array}{c}-0.116 * * * \\
(0.032)\end{array}$ & $\begin{array}{c}-0.072 * * \\
(0.036)\end{array}$ & $\begin{array}{c}-0.130^{* * * *} \\
(0.037)\end{array}$ & $\begin{array}{l}-0.050 \\
(0.034)\end{array}$ & $\begin{array}{l}-0.043 \\
(0.040)\end{array}$ & $\begin{array}{l}-0.065 \\
(0.042)\end{array}$ \\
\hline$\%$ Women in Natl Parliament & $\begin{array}{l}-0.018 \\
(0.019)\end{array}$ & $\begin{array}{c}-0.093 * * * \\
(0.035)\end{array}$ & $\begin{array}{c}0.021 \\
(0.027)\end{array}$ & $\begin{array}{l}-0.010 \\
(0.016)\end{array}$ & $\begin{array}{c}0.004 \\
(0.024)\end{array}$ & $\begin{array}{l}-0.014 \\
(0.017)\end{array}$ & $\begin{array}{l}-0.048^{*} \\
(0.027)\end{array}$ & $\begin{array}{l}-0.011 \\
(0.036)\end{array}$ & $\begin{array}{c}-0.069 * * \\
(0.031)\end{array}$ & $\begin{array}{l}-0.040 \\
(0.025)\end{array}$ & $\begin{array}{l}-0.025 \\
(0.035)\end{array}$ & $\begin{array}{l}-0.049 \\
(0.035)\end{array}$ \\
\hline$\%$ Women with degree & $\begin{array}{l}-0.009 \\
(0.006)\end{array}$ & $\begin{array}{l}-0.005 \\
(0.009)\end{array}$ & $\begin{array}{l}-0.010 \\
(0.008)\end{array}$ & $\begin{array}{c}0.004 \\
(0.004)\end{array}$ & $\begin{array}{c}0.003 \\
(0.008)\end{array}$ & $\begin{array}{c}0.005 \\
(0.004)\end{array}$ & $\begin{array}{c}0.015^{* *} \\
(0.007)\end{array}$ & $\begin{array}{c}0.023 * * * \\
(0.008)\end{array}$ & $\begin{array}{c}0.010 \\
(0.008)\end{array}$ & $\begin{array}{c}0.010 \\
(0.008)\end{array}$ & $\begin{array}{c}0.004 \\
(0.009)\end{array}$ & $\begin{array}{c}0.014 \\
(0.009)\end{array}$ \\
\hline Gender Equality Index & $\begin{array}{l}-0.007 \\
(0.018)\end{array}$ & $\begin{array}{c}0.036 \\
(0.041)\end{array}$ & $\begin{array}{c}-0.029 \\
(0.021)\end{array}$ & $\begin{array}{c}0.007 \\
(0.020)\end{array}$ & $\begin{array}{l}-0.002 \\
(0.031)\end{array}$ & $\begin{array}{c}0.014 \\
(0.020)\end{array}$ & $\begin{array}{c}0.043 \\
(0.034)\end{array}$ & $\begin{array}{c}0.033 \\
(0.036)\end{array}$ & $\begin{array}{c}0.051 \\
(0.038)\end{array}$ & $\begin{array}{c}0.014 \\
(0.032)\end{array}$ & $\begin{array}{c}-0.015 \\
(0.033)\end{array}$ & $\begin{array}{c}0.035 \\
(0.043)\end{array}$ \\
\hline Age & $\begin{array}{c}-0.021 * * \\
(0.010)\end{array}$ & $\begin{array}{l}-0.002 \\
(0.019)\end{array}$ & $\begin{array}{c}-0.031 * * * \\
(0.010)\end{array}$ & $\begin{array}{l}-0.002 \\
(0.008)\end{array}$ & $\begin{array}{l}-0.013 \\
(0.014)\end{array}$ & $\begin{array}{c}0.003 \\
(0.008)\end{array}$ & $\begin{array}{c}0.023 * * * \\
(0.009)\end{array}$ & $\begin{array}{c}0.012 \\
(0.020)\end{array}$ & $\begin{array}{c}0.026 * * * \\
(0.007)\end{array}$ & $\begin{array}{c}0.012 \\
(0.008)\end{array}$ & $\begin{array}{c}0.017 \\
(0.020)\end{array}$ & $\begin{array}{c}0.009 \\
(0.009)\end{array}$ \\
\hline Constant & $\begin{array}{c}2.080 \\
(1.647)\end{array}$ & $\begin{array}{c}0.392 \\
(3.051)\end{array}$ & $\begin{array}{c}2.773 \\
(1.815)\end{array}$ & $\begin{array}{l}-1.724 \\
(1.478)\end{array}$ & $\begin{array}{l}-1.105 \\
(2.519)\end{array}$ & $\begin{array}{c}-2.245^{*} \\
(1.337)\end{array}$ & $\begin{array}{c}-5.484^{* *} * \\
(2.274)\end{array}$ & $\begin{array}{c}-7.043^{* * * *} \\
(2.645)\end{array}$ & $\begin{array}{c}-4.470^{*} \\
(2.522)\end{array}$ & $\begin{array}{l}-2.719 \\
(2.283)\end{array}$ & $\begin{array}{c}-0.983 \\
(2.295)\end{array}$ & $\begin{array}{l}-3.961 \\
(2.990)\end{array}$ \\
\hline Observations & 745 & 273 & 472 & 745 & 273 & 472 & 745 & 273 & 472 & 745 & 273 & 472 \\
\hline Pseudo $\mathrm{R}^{2}$ & 0.0402 & 0.0821 & 0.0456 & 0.00426 & 0.00987 & 0.0134 & 0.0664 & 0.0702 & 0.0738 & 0.0325 & 0.0343 & 0.0431 \\
\hline Wald $X^{2}(12)$ & 166.6 & 30.34 & 92.59 & 9.478 & 4.320 & 46.49 & 53.73 & 29.58 & 47.80 & 31.49 & 11.89 & 18.23 \\
\hline Prob $>X^{2}$ & 0.000 & 0.000 & 0.000 & 0.304 & 0.827 & 0.000 & 0.000 & 0.000 & 0.000 & 0.000 & 0.156 & 0.020 \\
\hline
\end{tabular}


'United in Diversity?' Assessing the Effect of Varied Gender Quotas on

Legislator Experience in the European Parliament

Andrea S Aldrich

William T Daniel

Supplemental Materials

1. Appendix of Figures and Tables

Figure A1.1 Predicted Probabilities of Male MEPs and Experience

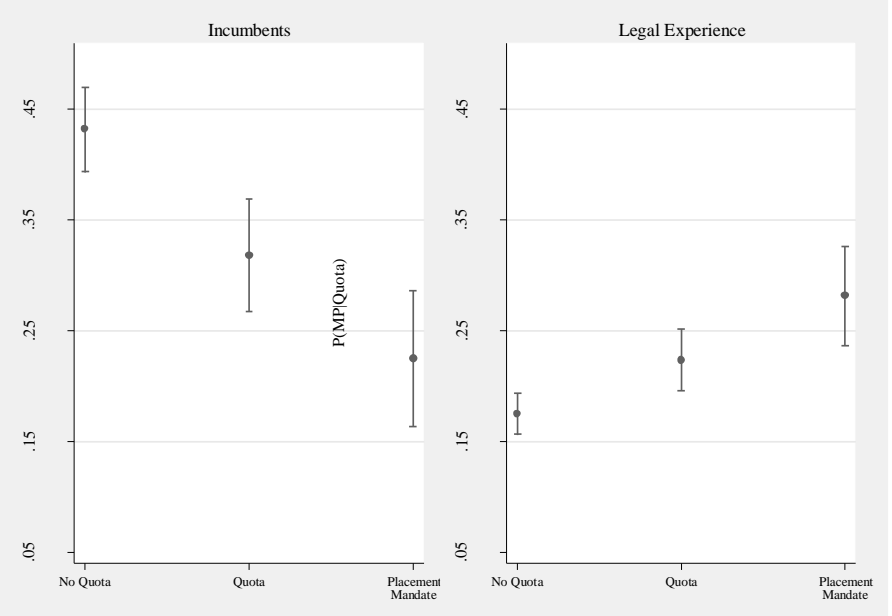


Table S1.1 All MEPs and Additional Professional Experience

\begin{tabular}{lccccc}
\hline VARIABLES & $\begin{array}{c}(1) \\
\text { Agriculture }\end{array}$ & $\begin{array}{c}(2) \\
\text { Med }\end{array}$ & $\begin{array}{c}(3) \\
\text { Transportation } \\
\text { and Telecom }\end{array}$ & $\begin{array}{c}(4) \\
\text { Teacher }\end{array}$ & $\begin{array}{c}(5) \\
\text { Journalist }\end{array}$ \\
\hline National Gender Quota & -0.097 & 0.047 & $-0.867 * * *$ & $0.307 * * *$ & 0.154 \\
& $(0.169)$ & $(0.222)$ & $(0.225)$ & $(0.070)$ & $(0.101)$ \\
Closed List & 0.172 & -0.219 & 0.322 & $0.710^{* * *}$ & $-0.980 * * *$ \\
& $(0.480)$ & $(0.442)$ & $(0.378)$ & $(0.113)$ & $(0.224)$ \\
Disproportionality & -0.089 & 0.074 & -0.008 & -0.021 & 0.022 \\
& $(0.119)$ & $(0.064)$ & $(0.108)$ & $(0.038)$ & $(0.061)$ \\
\# of Districts & 0.042 & -0.013 & -0.022 & $-0.067 * * *$ & $-0.084 * * *$ \\
& $(0.044)$ & $(0.033)$ & $(0.044)$ & $(0.019)$ & $(0.024)$ \\
\% Women in Natl Parliament & 0.017 & -0.013 & 0.027 & $-0.024 * * *$ & 0.009 \\
& $(0.023)$ & $(0.033)$ & $(0.024)$ & $(0.009)$ & $(0.018)$ \\
\% Women with degree & 0.001 & -0.009 & 0.000 & $0.017 * * *$ & 0.004 \\
& $(0.009)$ & $(0.009)$ & $(0.007)$ & $(0.003)$ & $(0.005)$ \\
\% Regular Service Attendance & -0.003 & 0.016 & 0.008 & $0.009 *$ & 0.007 \\
& $(0.013)$ & $(0.012)$ & $(0.014)$ & $(0.006)$ & $(0.009)$ \\
Age & $0.033 * *$ & 0.000 & 0.011 & $0.021 * * *$ & $0.029 * * *$ \\
& $(0.014)$ & $(0.017)$ & $(0.012)$ & $(0.008)$ & $(0.010)$ \\
Constant & $-4.747 *$ & -2.330 & $-4.012 *$ & $-4.850 * * *$ & $-4.267 * * *$ \\
& $(2.852)$ & $(2.283)$ & $(2.318)$ & $(0.744)$ & $(1.463)$ \\
Observations & & & & & \\
Pseudo R ${ }^{2}$ & 745 & 745 & 745 & 745 & 745 \\
Wald X ${ }^{2}(12)$ & 0.0260 & 0.0189 & 0.0437 & 0.0658 & 0.0592 \\
Prob $>X^{2}$ & 13.79 & 6.377 & 30.60 & 140 & 102.1 \\
& 0.0874 & 0.605 & 0.000 & 0.000 & 0.000 \\
\hline
\end{tabular}


Table S1.2 Female MEPs and Additional Professional Experience

\begin{tabular}{|c|c|c|c|c|c|}
\hline VARIABLES & $\begin{array}{c}(1) \\
\text { Agriculture }\end{array}$ & $\begin{array}{l}\text { (2) } \\
\text { Med }\end{array}$ & $\begin{array}{c}\text { (3) } \\
\text { Transportation } \\
\text { and Telecom }\end{array}$ & $\begin{array}{c}(4) \\
\text { Teacher }\end{array}$ & $\begin{array}{c}\text { (5) } \\
\text { Journalist }\end{array}$ \\
\hline National Gender Quota & $\begin{array}{c}1.097 * * \\
(0.438)\end{array}$ & $\begin{array}{c}-0.158 \\
(0.374)\end{array}$ & $\begin{array}{c}-0.547 * * * \\
(0.195)\end{array}$ & $\begin{array}{c}0.251 * \\
(0.130)\end{array}$ & $\begin{array}{c}0.266 \\
(0.207)\end{array}$ \\
\hline Closed List & $\begin{array}{l}-0.656 \\
(0.574)\end{array}$ & $\begin{array}{c}-0.677 \\
(0.852)\end{array}$ & $\begin{array}{c}0.079 \\
(0.415)\end{array}$ & $\begin{array}{c}0.420 \\
(0.381)\end{array}$ & $\begin{array}{c}-2.651 * * * \\
(0.515)\end{array}$ \\
\hline Disproportionality & $\begin{array}{l}-0.281 \\
(0.176)\end{array}$ & $\begin{array}{c}0.083 \\
(0.091)\end{array}$ & $\begin{array}{c}0.055 \\
(0.097)\end{array}$ & $\begin{array}{c}0.004 \\
(0.071)\end{array}$ & $\begin{array}{c}0.011 \\
(0.101)\end{array}$ \\
\hline \# of Districts & $\begin{array}{c}-0.489^{*} \\
(0.290)\end{array}$ & $\begin{array}{c}-0.001 \\
(0.066)\end{array}$ & $\begin{array}{c}-0.170 * * * \\
(0.039)\end{array}$ & $\begin{array}{c}-0.038 \\
(0.025)\end{array}$ & $\begin{array}{c}-0.139 * * \\
(0.057)\end{array}$ \\
\hline$\%$ Women in Natl Parliament & $\begin{array}{l}-0.080 \\
(0.064)\end{array}$ & $\begin{array}{c}0.006 \\
(0.053)\end{array}$ & $\begin{array}{c}-0.009 \\
(0.032)\end{array}$ & $\begin{array}{c}-0.027 \\
(0.022)\end{array}$ & $\begin{array}{c}0.008 \\
(0.031)\end{array}$ \\
\hline$\%$ Women with degree & $\begin{array}{c}-0.043 * * \\
(0.021)\end{array}$ & $\begin{array}{c}-0.009 \\
(0.010)\end{array}$ & $\begin{array}{c}-0.020^{*} \\
(0.012)\end{array}$ & $\begin{array}{c}0.014 * * * \\
(0.005)\end{array}$ & $\begin{array}{c}0.008 \\
(0.010)\end{array}$ \\
\hline$\%$ Regular Service Attendance & $\begin{array}{c}-0.152 * * * \\
(0.055)\end{array}$ & $\begin{array}{c}0.012 \\
(0.019)\end{array}$ & $\begin{array}{c}-0.006 \\
(0.015)\end{array}$ & $\begin{array}{l}0.020^{*} \\
(0.012)\end{array}$ & $\begin{array}{c}0.017 \\
(0.015)\end{array}$ \\
\hline Age & $\begin{array}{c}0.073 * * \\
(0.029)\end{array}$ & $\begin{array}{c}0.015 \\
(0.030)\end{array}$ & $\begin{array}{c}-0.004 \\
(0.030)\end{array}$ & $\begin{array}{c}0.020 \\
(0.014)\end{array}$ & $\begin{array}{c}0.031 \\
(0.022)\end{array}$ \\
\hline Constant & $\begin{array}{c}7.092 \\
(5.446)\end{array}$ & $\begin{array}{l}-2.953 \\
(3.049)\end{array}$ & $\begin{array}{c}1.385 \\
(3.006)\end{array}$ & $\begin{array}{c}-4.915 * * \\
(2.031)\end{array}$ & $\begin{array}{c}-4.810 * \\
(2.558)\end{array}$ \\
\hline Observations & 273 & 273 & 273 & 273 & 273 \\
\hline Pseudo $\mathrm{R}^{2}$ & 0.209 & 0.0326 & 0.0680 & 0.0657 & 0.179 \\
\hline Wald $X^{2}(12)$ & 793.6 & 4.905 & 139.1 & 52.59 & 45.73 \\
\hline Prob $>X^{2}$ & 0.000 & 0.768 & 0.000 & 0.000 & 0.000 \\
\hline
\end{tabular}


Table S1.3 Male MEPs and Additional Professional Experience

\begin{tabular}{|c|c|c|c|c|c|c|}
\hline VARIABLES & $\begin{array}{c}\text { (1) } \\
\text { Agriculture }\end{array}$ & $\begin{array}{c}(2) \\
\text { Med }\end{array}$ & $\begin{array}{c}(3) \\
\text { Transportation } \\
\text { and Telecom } \\
\end{array}$ & $\begin{array}{c}\text { (4) } \\
\text { Teacher }\end{array}$ & $\begin{array}{c}(5) \\
\text { Journalist }\end{array}$ & $\begin{array}{c}\text { (6) } \\
\text { Agriculture }\end{array}$ \\
\hline National Gender Quota & $\begin{array}{l}-0.312 \\
(0.333)\end{array}$ & $\begin{array}{c}0.299 \\
(0.302)\end{array}$ & $\begin{array}{c}-0.192 * * * \\
(0.068)\end{array}$ & $\begin{array}{c}-1.250 * * * \\
(0.348)\end{array}$ & $\begin{array}{c}0.350 * * * \\
(0.091)\end{array}$ & $\begin{array}{c}0.176 \\
(0.136)\end{array}$ \\
\hline Closed List & $\begin{array}{c}0.188 \\
(0.684)\end{array}$ & $\begin{array}{c}0.099 \\
(0.609)\end{array}$ & $\begin{array}{c}0.567 * * * \\
(0.156)\end{array}$ & $\begin{array}{c}0.470 \\
(0.507)\end{array}$ & $\begin{array}{c}0.874 * * * \\
(0.187)\end{array}$ & $\begin{array}{l}-0.486 \\
(0.297)\end{array}$ \\
\hline Disproportionality & $\begin{array}{l}-0.027 \\
(0.154)\end{array}$ & $\begin{array}{c}0.061 \\
(0.101)\end{array}$ & $\begin{array}{l}-0.013 \\
(0.042)\end{array}$ & $\begin{array}{l}-0.100 \\
(0.175)\end{array}$ & $\begin{array}{l}-0.030 \\
(0.051)\end{array}$ & $\begin{array}{c}0.019 \\
(0.066)\end{array}$ \\
\hline \# of Districts & $\begin{array}{c}0.062 \\
(0.050)\end{array}$ & $\begin{array}{l}-0.016 \\
(0.038)\end{array}$ & $\begin{array}{l}-0.003 \\
(0.012)\end{array}$ & $\begin{array}{c}0.054 \\
(0.054)\end{array}$ & $\begin{array}{c}-0.074 * * * \\
(0.026)\end{array}$ & $\begin{array}{c}-0.066 * * \\
(0.026)\end{array}$ \\
\hline$\%$ Women in Natl Parliament & $\begin{array}{c}0.012 \\
(0.027)\end{array}$ & $\begin{array}{c}-0.039 \\
(0.033)\end{array}$ & $\begin{array}{c}-0.003 \\
(0.013)\end{array}$ & $\begin{array}{c}0.040 \\
(0.027)\end{array}$ & $\begin{array}{c}-0.017 * * \\
(0.008)\end{array}$ & $\begin{array}{c}0.011 \\
(0.025)\end{array}$ \\
\hline$\%$ Women with degree & $\begin{array}{l}-0.001 \\
(0.012)\end{array}$ & $\begin{array}{l}-0.009 \\
(0.009)\end{array}$ & $\begin{array}{c}0.004 \\
(0.004)\end{array}$ & $\begin{array}{c}0.014 \\
(0.008)\end{array}$ & $\begin{array}{c}0.020 * * * \\
(0.005)\end{array}$ & $\begin{array}{c}0.003 \\
(0.008)\end{array}$ \\
\hline \% Regular Service Attendance & $\begin{array}{c}0.006 \\
(0.017)\end{array}$ & $\begin{array}{c}0.021 \\
(0.015)\end{array}$ & $\begin{array}{c}0.003 \\
(0.006)\end{array}$ & $\begin{array}{c}0.002 \\
(0.019)\end{array}$ & $\begin{array}{c}0.004 \\
(0.008)\end{array}$ & $\begin{array}{c}0.002 \\
(0.010)\end{array}$ \\
\hline Age & $\begin{array}{c}0.024 \\
(0.017)\end{array}$ & $\begin{array}{l}-0.008 \\
(0.015)\end{array}$ & $\begin{array}{c}0.003 \\
(0.008)\end{array}$ & $\begin{array}{l}0.021 * \\
(0.011)\end{array}$ & $\begin{array}{l}0.020 * \\
(0.011)\end{array}$ & $\begin{array}{c}0.029 * * \\
(0.011)\end{array}$ \\
\hline Constant & $\begin{array}{c}-4.300 \\
(3.746)\end{array}$ & $\begin{array}{l}-1.727 \\
(2.693)\end{array}$ & $\begin{array}{c}-1.861 * * \\
(0.942)\end{array}$ & $\begin{array}{c}-6.535^{* *} \\
(2.785)\end{array}$ & $\begin{array}{c}-5.241 * * * \\
(1.017)\end{array}$ & $\begin{array}{c}-4.277 * * \\
(1.980)\end{array}$ \\
\hline Observations & 472 & 472 & 472 & 472 & 472 & 472 \\
\hline Pseudo $\mathrm{R}^{2}$ & 0.0248 & 0.0310 & 0.0131 & 0.0735 & 0.0735 & 0.0333 \\
\hline Wald $X^{2}(12)$ & 9.661 & 14.20 & 42.18 & 30.63 & 140.3 & 56.60 \\
\hline Prob $>X^{2}$ & 0.290 & 0.0766 & 0.000 & 0.000 & 0.000 & 0.000 \\
\hline
\end{tabular}


Table S1.4 Gender and Experience in the European Parliament

\begin{tabular}{|c|c|c|c|c|c|c|c|c|c|c|c|c|c|}
\hline & & \multicolumn{4}{|c|}{ Entire Population } & \multicolumn{4}{|c|}{ Quota Countries } & \multicolumn{4}{|c|}{ Placement Countries } \\
\hline & & Women & Men & All & $p$ & Women & Men & All & $p$ & Women & Men & All & $p$ \\
\hline & Gender & 276 & 476 & 752 & & 87 & 163 & 250 & & 67 & 103 & 170 & \\
\hline Political & National Party Office & $\underline{40}$ & $\underline{109}$ & $\underline{149}$ & $\underline{0.005}$ & $\underline{14}$ & $\underline{43}$ & $\underline{57}$ & $\underline{0.065}$ & 14 & 34 & 48 & 0.184 \\
\hline \multirow[t]{3}{*}{ Office } & Former MP & $\underline{85}$ & $\underline{181}$ & $\underline{266}$ & $\underline{0.046}$ & $\underline{26}$ & $\underline{70}$ & $\underline{96}$ & $\underline{0.043}$ & 14 & 32 & 46 & 0.145 \\
\hline & Former Local Politician & $\underline{130}$ & $\underline{190}$ & $\underline{\mathbf{3 2 0}}$ & $\underline{0.050}$ & 46 & $\overline{73}$ & 119 & 0.223 & 38 & 60 & 98 & 0.843 \\
\hline & Incumbent & 136 & 223 & 359 & 0.521 & 41 & 65 & 106 & 0.269 & 34 & 46 & 80 & 0.334 \\
\hline Professional. & Agriculture $^{1}$ & 12 & 34 & 46 & 0.125 & 5 & 11 & 16 & 0.749 & 5 & 5 & 10 & 0.48 \\
\hline \multirow[t]{8}{*}{ Experience } & Legal & 54 & 113 & 167 & 0.190 & 25 & 47 & 72 & 0.963 & 23 & 37 & 60 & 0.832 \\
\hline & Medical & 15 & 16 & 31 & 0.166 & 3 & 6 & 9 & 0.918 & 3 & 5 & 8 & 0.91 \\
\hline & Economic and Finance & 67 & 131 & 67 & 0.339 & 23 & 40 & 63 & 0.763 & 15 & 25 & 40 & 0.777 \\
\hline & Transportation and Telecom & 20 & 30 & 50 & 0.610 & 3 & 5 & 8 & 0.877 & $\underline{2}$ & $\underline{0}$ & 2 & 0.078 \\
\hline & Teacher & $\underline{42}$ & $\underline{108}$ & $\underline{150}$ & $\underline{0.014}$ & 17 & 46 & 63 & 0.125 & 11 & 30 & 41 & 0.058 \\
\hline & International & 64 & $\overline{127}$ & $\overline{191}$ & 0.297 & 22 & 47 & 69 & 0.531 & 16 & 25 & 41 & 0.954 \\
\hline & $\mathrm{PhD}$ & $\underline{44}$ & $\underline{100}$ & $\underline{144}$ & $\underline{0.091}$ & $\underline{10}$ & $\underline{44}$ & $\underline{54}$ & $\underline{0.004}$ & $\underline{7}$ & $\underline{\mathbf{2 3}}$ & 30 & $\underline{0.047}$ \\
\hline & Journalist & 28 & 52 & 80 & 0.747 & 7 & 19 & 26 & 0.365 & $\underline{2}$ & $\underline{13}$ & 15 & $\underline{0.03}$ \\
\hline \multirow[t]{11}{*}{ Age } & Age $\geq 20 \&<30$ & 6 & 10 & 16 & 0.095 & 0 & 1 & 1 & 0.464 & 0 & 1 & 1 & 0.419 \\
\hline & Age $\geq 30 \&<40$ & 44 & 56 & 100 & 0.104 & 12 & 15 & 27 & 0.0265 & 11 & 12 & 23 & 0.375 \\
\hline & Age $\geq 40 \&<50$ & 72 & 129 & 201 & 0.762 & 24 & 34 & 58 & 0.23 & 16 & 23 & 39 & 0.814 \\
\hline & Age $\geq 50 \&<60$ & 102 & 155 & 257 & 0.221 & 30 & 64 & 94 & 0.457 & 23 & 39 & 62 & 0.64 \\
\hline & Age $\geq 60 \&<70$ & 45 & 103 & 148 & 0.076 & 18 & 36 & 54 & 0.798 & 14 & 21 & 35 & 0.94 \\
\hline & Age $\geq 70 \&<80$ & 7 & 21 & 28 & 0.190 & 3 & 11 & 14 & 0.28 & 3 & 6 & 9 & 0.701 \\
\hline & Age $\geq 80$ & 0 & 2 & 2 & 0.281 & 0 & 2 & 2 & 0.3 & 0 & 1 & 1 & 0.419 \\
\hline & Age $<40$ & 50 & 66 & 116 & 0.120 & 12 & 16 & 28 & 0.342 & 11 & 13 & 24 & 0.487 \\
\hline & Age $>60$ & $\underline{52}$ & $\underline{126}$ & $\underline{178}$ & $\underline{0.018}$ & 21 & 49 & 70 & 0.32 & 17 & 28 & 45 & 0.0794 \\
\hline & $\mathrm{N}$ of Gender Group & 276 & 476 & & & 90 & 169 & & & 70 & 107 & & \\
\hline & $\mathrm{N}$ of Experience Subgroup & 752 & 752 & & & 259 & 259 & & & 177 & 177 & & \\
\hline
\end{tabular}

${ }^{1}$ For all professional categories, $\mathrm{N}=745$ and thus the percentage calculations for these experience categories use 745 as the denominator. Categories are not necessarily mutually exclusive. 


\section{Party level Analysis}

In addition to analysis conducted at the national level, we also chose to investigate the relationship between gender quotas at the party level and MEP experience. At the party level, we are able to account for voluntary gender quotas and placement mandates, in addition to national gender requirements. These are quotas in parties where there is no national law on gender quotas or in parties that have rules that go above and beyond the national law. Data on gender quotas at the party level is taken in part from Brodolini et al. (2014), which provides data for parties that were serving in the EP and had registered electoral lists for the European Election of 2014, as of May 2014. This was supplemented, when necessary, by the Quota Project, which includes data on all parties serving in the national parliaments of EU member states. Parties that serve in the EP are excluded from this data if we were unable to confirm either the presence of a quota or its absence. In addition, the control variables listed above, we are also able to control for ideology at the party level. We do this with a series of party family variables. These include radical right, conservative, liberal, Christian democrat, socialist, radical left, and green parties. These data come from the 2014 Chapel Hill Expert Survey (Polk et al. 2017).

Tables S2.1 and S2.2 report the results of similar logistic regression models to those analyzed in text with a smaller subset of MEPs and also including party-level data for political experience professional experience. The results reported below largely confirm the conclusions of the text but have less power given the availability of the data at the party level. Party Gender quotes, while not increase the likelihood that female MEPs will have been national MPS, decrease the likelihood that Male MEPs will have this type of experience. National gender quotas again increase the likelihood that male MEPs will have held national party office and decrease the likelihood that they will be incumbents. Table S2.2 shows that party quotas little effect on the type professionally experience MEPs serve in the EP. This table shows that national quotas are much more important in influencing the type of MEP representing each party and country. 
Table S2.1 Professional Experience and Party Gender Quotas

\begin{tabular}{|c|c|c|c|c|c|c|c|c|c|c|c|c|}
\hline \multirow[t]{2}{*}{ VARIABLES } & \multicolumn{3}{|c|}{ (1) } & \multicolumn{3}{|c|}{$\begin{array}{c}(2) \\
\text { Former MPs }\end{array}$} & \multicolumn{3}{|c|}{$\begin{array}{c}(3) \\
\text { Local Politicians }\end{array}$} & \multicolumn{3}{|c|}{$\begin{array}{c}(4) \\
\text { Incumbents }\end{array}$} \\
\hline & All & Female & Male & All & Female & Male & All & Female & Male & All & Female & Male \\
\hline Party Gender Quota & $\begin{array}{c}0.332 \\
(0.318)\end{array}$ & $\begin{array}{c}0.324 \\
(0.363)\end{array}$ & $\begin{array}{c}0.240 \\
(0.372)\end{array}$ & $\begin{array}{c}-0.547 * * * \\
(0.205)\end{array}$ & $\begin{array}{l}-0.502 \\
(0.527)\end{array}$ & $\begin{array}{c}-0.657 * * * \\
(0.223)\end{array}$ & $\begin{array}{l}-0.062 \\
(0.242)\end{array}$ & $\begin{array}{l}-0.100 \\
(0.309)\end{array}$ & $\begin{array}{l}-0.096 \\
(0.264)\end{array}$ & $\begin{array}{l}-0.449 \\
(0.298)\end{array}$ & $\begin{array}{l}-0.279 \\
(0.326)\end{array}$ & $\begin{array}{l}-0.473 \\
(0.384)\end{array}$ \\
\hline National Gender Quota & $\begin{array}{c}0.458 * * * \\
(0.153)\end{array}$ & $\begin{array}{c}0.203 \\
(0.396)\end{array}$ & $\begin{array}{l}0.441 * * \\
(0.179)\end{array}$ & $\begin{array}{l}-0.038 \\
(0.150)\end{array}$ & $\begin{array}{c}0.057 \\
(0.227)\end{array}$ & $\begin{array}{c}0.065 \\
(0.216)\end{array}$ & $\begin{array}{c}0.173 \\
(0.170)\end{array}$ & $\begin{array}{l}-0.149 \\
(0.265)\end{array}$ & $\begin{array}{c}0.382 * * \\
(0.174)\end{array}$ & $\begin{array}{c}-0.466 * * \\
(0.206)\end{array}$ & $\begin{array}{l}-0.088 \\
(0.294)\end{array}$ & $\begin{array}{c}-0.619 * * \\
(0.255)\end{array}$ \\
\hline Closed List & $\begin{array}{l}-0.868 * \\
(0.498)\end{array}$ & $\begin{array}{l}-0.320 \\
(0.850)\end{array}$ & $\begin{array}{c}-1.085^{* *} \\
(0.479)\end{array}$ & $\begin{array}{l}-0.222 \\
(0.273)\end{array}$ & $\begin{array}{c}-1.512 * * * \\
(0.402)\end{array}$ & $\begin{array}{c}0.443 \\
(0.388)\end{array}$ & $\begin{array}{l}0.581^{*} \\
(0.300)\end{array}$ & $\begin{array}{c}0.197 \\
(0.518)\end{array}$ & $\begin{array}{l}0.899 * * \\
(0.402)\end{array}$ & $\begin{array}{c}1.519 * * * \\
(0.500)\end{array}$ & $\begin{array}{l}1.056^{*} \\
(0.562)\end{array}$ & $\begin{array}{c}1.895^{* * *} \\
(0.678)\end{array}$ \\
\hline Disproportionality & $\begin{array}{l}0.037 \\
(0.066)\end{array}$ & $\begin{array}{c}0.027 \\
(0.150)\end{array}$ & $\begin{array}{l}0.096 \\
(0.074)\end{array}$ & $\begin{array}{c}0.152 * * * \\
(0.047)\end{array}$ & $\begin{array}{c}0.182 * * * \\
(0.050)\end{array}$ & $\begin{array}{l}0.143^{*} \\
(0.086)\end{array}$ & $\begin{array}{l}0.108 \\
(0.076)\end{array}$ & $\begin{array}{l}0.037 \\
(0.097)\end{array}$ & $\begin{array}{l}0.149^{*} \\
(0.088)\end{array}$ & $\begin{array}{c}0.017 \\
(0.085)\end{array}$ & $\begin{array}{l}-0.137 \\
(0.143)\end{array}$ & $\begin{array}{c}0.082 \\
(0.090)\end{array}$ \\
\hline \# of Districts & $\begin{array}{c}-0.148 * * * \\
(0.039)\end{array}$ & $\begin{array}{c}-0.195 * * \\
(0.089)\end{array}$ & $\begin{array}{c}-0.146 * * * \\
(0.041)\end{array}$ & $\begin{array}{c}-0.136 * * * \\
(0.024)\end{array}$ & $\begin{array}{c}-0.148 * * \\
(0.070)\end{array}$ & $\begin{array}{c}-0.143 * * * \\
(0.035)\end{array}$ & $\begin{array}{l}-0.018 \\
(0.030)\end{array}$ & $\begin{array}{l}-0.018 \\
(0.042)\end{array}$ & $\begin{array}{l}-0.036 \\
(0.034)\end{array}$ & $\begin{array}{l}-0.064^{*} \\
(0.037)\end{array}$ & $\begin{array}{c}-0.106^{* *} \\
(0.044)\end{array}$ & $\begin{array}{l}-0.049 \\
(0.051)\end{array}$ \\
\hline Women in Natl Parliament & $\begin{array}{l}-0.042 \\
(0.027)\end{array}$ & $\begin{array}{c}0.035 \\
(0.059)\end{array}$ & $\begin{array}{c}-0.049 \\
(0.030)\end{array}$ & $\begin{array}{l}0.029 * \\
(0.017)\end{array}$ & $\begin{array}{c}0.001 \\
(0.032)\end{array}$ & $\begin{array}{c}0.034 \\
(0.027)\end{array}$ & $\begin{array}{c}0.073 * * * \\
(0.021)\end{array}$ & $\begin{array}{l}0.059 * \\
(0.033)\end{array}$ & $\begin{array}{c}0.085 * * * \\
(0.025)\end{array}$ & $\begin{array}{l}0.045^{*} \\
(0.026)\end{array}$ & $\begin{array}{l}-0.035 \\
(0.037)\end{array}$ & $\begin{array}{c}0.072 * * \\
(0.033)\end{array}$ \\
\hline Women with Degree & $\begin{array}{c}0.003 \\
(0.008)\end{array}$ & $\begin{array}{l}-0.003 \\
(0.010)\end{array}$ & $\begin{array}{c}0.008 \\
(0.010)\end{array}$ & $\begin{array}{c}0.043 * * * \\
(0.006)\end{array}$ & $\begin{array}{c}0.047 * * * \\
(0.012)\end{array}$ & $\begin{array}{c}0.044 * * * \\
(0.008)\end{array}$ & $\begin{array}{c}0.004 \\
(0.006)\end{array}$ & $\begin{array}{l}-0.000 \\
(0.007)\end{array}$ & $\begin{array}{c}0.007 \\
(0.008)\end{array}$ & $\begin{array}{c}0.005 \\
(0.006)\end{array}$ & $\begin{array}{c}0.002 \\
(0.010)\end{array}$ & $\begin{array}{c}0.005 \\
(0.006)\end{array}$ \\
\hline Religiosity & $\begin{array}{c}0.002 \\
(0.007)\end{array}$ & $\begin{array}{c}0.009 \\
(0.026)\end{array}$ & $\begin{array}{c}0.003 \\
(0.009)\end{array}$ & $\begin{array}{c}0.022 * * * \\
(0.007)\end{array}$ & $\begin{array}{c}0.017 \\
(0.012)\end{array}$ & $\begin{array}{c}0.028 * * \\
(0.011)\end{array}$ & $\begin{array}{c}0.002 \\
(0.011)\end{array}$ & $\begin{array}{c}0.005 \\
(0.017)\end{array}$ & $\begin{array}{c}0.005 \\
(0.012)\end{array}$ & $\begin{array}{c}0.003 \\
(0.014)\end{array}$ & $\begin{array}{l}-0.022 \\
(0.017)\end{array}$ & $\begin{array}{c}0.010 \\
(0.016)\end{array}$ \\
\hline Age & $\begin{array}{c}0.039 * * \\
(0.015)\end{array}$ & $\begin{array}{c}0.055 \\
(0.037)\end{array}$ & $\begin{array}{l}0.030 * \\
(0.017)\end{array}$ & $\begin{array}{c}0.058 * * * \\
(0.010)\end{array}$ & $\begin{array}{c}0.071 * * * \\
(0.027)\end{array}$ & $\begin{array}{c}0.058 * * * \\
(0.013)\end{array}$ & $\begin{array}{c}0.016 * * \\
(0.007)\end{array}$ & $\begin{array}{c}0.049 * * * \\
(0.013)\end{array}$ & $\begin{array}{c}0.003 \\
(0.009)\end{array}$ & $\begin{array}{c}0.056^{* * * *} \\
(0.011)\end{array}$ & $\begin{array}{l}0.040 * \\
(0.023)\end{array}$ & $\begin{array}{c}0.070 * * * \\
(0.016)\end{array}$ \\
\hline Radical Right & $\begin{array}{c}0.350 \\
(0.679)\end{array}$ & $\begin{array}{c}1.396 \\
(1.378)\end{array}$ & $\begin{array}{c}0.209 \\
(0.700)\end{array}$ & $\begin{array}{c}-0.596 \\
(0.381)\end{array}$ & $\begin{array}{l}-1.926 \\
(1.746)\end{array}$ & $\begin{array}{l}-0.400 \\
(0.421)\end{array}$ & $\begin{array}{c}0.665 \\
(0.921)\end{array}$ & $\begin{array}{c}1.568 \\
(1.489)\end{array}$ & $\begin{array}{c}0.445 \\
(0.915)\end{array}$ & $\begin{array}{l}-1.375 \\
(0.908)\end{array}$ & $\begin{array}{c}-3.741 * * \\
(1.598)\end{array}$ & $\begin{array}{l}-1.008 \\
(0.888)\end{array}$ \\
\hline Conservative & $\begin{array}{l}-1.165 \\
(0.774)\end{array}$ & & $\begin{array}{l}-0.860 \\
(0.759)\end{array}$ & $\begin{array}{c}-1.341 * * * \\
(0.496)\end{array}$ & $\begin{array}{l}-1.600 \\
(1.810)\end{array}$ & $\begin{array}{c}-1.182^{*} \\
(0.674)\end{array}$ & $\begin{array}{c}0.418 \\
(0.795)\end{array}$ & $\begin{array}{c}0.237 \\
(1.391)\end{array}$ & $\begin{array}{c}0.515 \\
(0.800)\end{array}$ & $\begin{array}{l}-0.136 \\
(0.865)\end{array}$ & $\begin{array}{c}-1.172 \\
(1.454)\end{array}$ & $\begin{array}{c}0.015 \\
(0.919)\end{array}$ \\
\hline Liberal & $\begin{array}{c}0.093 \\
(0.749)\end{array}$ & $\begin{array}{l}-0.829 \\
(1.582)\end{array}$ & $\begin{array}{c}0.634 \\
(0.664)\end{array}$ & $\begin{array}{l}-0.687 \\
(0.617)\end{array}$ & $\begin{array}{c}0.205 \\
(1.307)\end{array}$ & $\begin{array}{c}-1.321^{*} \\
(0.690)\end{array}$ & $\begin{array}{c}0.184 \\
(0.897)\end{array}$ & $\begin{array}{c}0.008 \\
(1.592)\end{array}$ & $\begin{array}{c}0.003 \\
(0.823)\end{array}$ & $\begin{array}{l}-0.417 \\
(0.794)\end{array}$ & $\begin{array}{l}-1.449 \\
(1.462)\end{array}$ & $\begin{array}{l}-0.140 \\
(0.847)\end{array}$ \\
\hline Christian Democrat & $\begin{array}{c}-1.505 * * \\
(0.721)\end{array}$ & $\begin{array}{l}-1.548 \\
(1.911)\end{array}$ & $\begin{array}{c}-1.442 * \\
(0.738)\end{array}$ & $\begin{array}{l}-0.918^{*} \\
(0.535)\end{array}$ & $\begin{array}{l}-1.793 \\
(1.552)\end{array}$ & $\begin{array}{l}-0.674 \\
(0.556)\end{array}$ & $\begin{array}{c}0.717 \\
(0.929)\end{array}$ & $\begin{array}{c}0.522 \\
(1.546)\end{array}$ & $\begin{array}{c}0.649 \\
(0.855)\end{array}$ & $\begin{array}{c}0.066 \\
(0.778)\end{array}$ & $\begin{array}{c}0.431 \\
(1.525)\end{array}$ & $\begin{array}{l}-0.194 \\
(0.803)\end{array}$ \\
\hline Socialist & $\begin{array}{l}-0.498 \\
(0.647)\end{array}$ & $\begin{array}{l}-1.125 \\
(1.645)\end{array}$ & $\begin{array}{c}0.021 \\
(0.650)\end{array}$ & $\begin{array}{l}-0.771 \\
(0.558)\end{array}$ & $\begin{array}{l}-0.082 \\
(1.557)\end{array}$ & $\begin{array}{c}-1.201^{*} \\
(0.647)\end{array}$ & $\begin{array}{c}0.455 \\
(0.776)\end{array}$ & $\begin{array}{c}0.139 \\
(1.417)\end{array}$ & $\begin{array}{c}0.477 \\
(0.626)\end{array}$ & $\begin{array}{l}-0.644 \\
(0.910)\end{array}$ & $\begin{array}{c}-1.378 \\
(1.600)\end{array}$ & $\begin{array}{l}-0.607 \\
(0.861)\end{array}$ \\
\hline Radical Left & $\begin{array}{l}-0.290 \\
(0.750)\end{array}$ & & $\begin{array}{c}0.381 \\
(0.693)\end{array}$ & $\begin{array}{c}-1.975 * * \\
(0.978)\end{array}$ & $\begin{array}{l}-1.034 \\
(1.610)\end{array}$ & $\begin{array}{c}-2.405 * * \\
(0.998)\end{array}$ & $\begin{array}{c}0.652 \\
(0.908)\end{array}$ & & $\begin{array}{l}-0.498 \\
(1.004)\end{array}$ & $\begin{array}{l}-0.184 \\
(0.796)\end{array}$ & $\begin{array}{l}-1.127 \\
(1.760)\end{array}$ & $\begin{array}{l}-0.019 \\
(0.798)\end{array}$ \\
\hline Green & $\begin{array}{l}-1.326 \\
(0.991)\end{array}$ & $\begin{array}{l}-1.988 \\
(1.537)\end{array}$ & $\begin{array}{l}-1.127 \\
(1.186)\end{array}$ & $\begin{array}{c}-1.407 * * \\
(0.550)\end{array}$ & $\begin{array}{l}-0.447 \\
(1.722)\end{array}$ & $\begin{array}{c}-1.682 * * \\
(0.779)\end{array}$ & $\begin{array}{l}-0.286 \\
(0.865)\end{array}$ & $\begin{array}{l}-0.411 \\
(1.324)\end{array}$ & $\begin{array}{l}-0.398 \\
(0.955)\end{array}$ & $\begin{array}{c}0.604 \\
(0.905)\end{array}$ & $\begin{array}{c}-0.437 \\
(1.540)\end{array}$ & $\begin{array}{c}0.918 \\
(1.088)\end{array}$ \\
\hline Constant & $\begin{array}{l}-1.924 \\
(2.124)\end{array}$ & $\begin{array}{l}-4.300 \\
(4.013)\end{array}$ & $\begin{array}{l}-2.393 \\
(2.361)\end{array}$ & $\begin{array}{c}-10.504 * * * \\
(1.501)\end{array}$ & $\begin{array}{c}-10.704 * * * \\
(2.336)\end{array}$ & $\begin{array}{c}-11.000 * * * \\
(2.144)\end{array}$ & $\begin{array}{c}-4.875 * * * \\
(1.395)\end{array}$ & $\begin{array}{c}-4.689 * * \\
(2.370)\end{array}$ & $\begin{array}{c}-5.536 * * * \\
(2.080)\end{array}$ & $\begin{array}{c}-4.493 * * \\
(2.165)\end{array}$ & $\begin{array}{c}1.661 \\
(2.847)\end{array}$ & $\begin{array}{c}-6.789 * * \\
(2.812)\end{array}$ \\
\hline Observations & 410 & 126 & 260 & 410 & 150 & 260 & 409 & 143 & 260 & 410 & 150 & 260 \\
\hline Pseudo $\mathrm{R}^{2}$ & 0.126 & 0.145 & 0.169 & 0.266 & 0.377 & 0.263 & 0.0738 & 0.0896 & 0.0925 & 0.152 & 0.210 & 0.174 \\
\hline Wald $X^{2}(12)$ & 124.7 & 129.9 & 126.1 & 487.1 & 419.8 & 235.3 & 87.92 & 54.06 & 127.1 & 195.7 & 151.7 & 156.6 \\
\hline Prob $>X^{2}$ & 0.000 & 0.000 & 0.000 & 0.000 & 0.000 & 0.000 & 0.000 & 0.000 & 0.000 & 0.000 & 0.000 & 0.000 \\
\hline
\end{tabular}


Table S2.2 Professional Experience and Party Gender Quotas

\begin{tabular}{|c|c|c|c|c|c|c|c|c|c|c|c|c|}
\hline \multirow[t]{2}{*}{ VARIABLES } & \multicolumn{3}{|c|}{$\begin{array}{c}(1) \\
\text { Legal }\end{array}$} & \multicolumn{3}{|c|}{$\begin{array}{c}(2) \\
\text { Economics and Finance } \\
\end{array}$} & \multicolumn{3}{|c|}{$\begin{array}{c}(3) \\
\text { International } \\
\end{array}$} & \multicolumn{3}{|c|}{$\begin{array}{c}4) \\
\mathrm{PhD} \\
\end{array}$} \\
\hline & All & Female & Male & All & Female & Male & All & Female & Male & All & Female & Male \\
\hline Party Gender Quota & $\begin{array}{l}0.168 \\
(0.200)\end{array}$ & $\begin{array}{l}-0.049 \\
(0.365)\end{array}$ & $\begin{array}{c}0.298 \\
(0.287)\end{array}$ & $\begin{array}{l}0.025 \\
(0.174)\end{array}$ & $\begin{array}{l}-0.268 \\
(0.326)\end{array}$ & $\begin{array}{c}0.182 \\
(0.207)\end{array}$ & $\begin{array}{c}0.259 \\
(0.241)\end{array}$ & $\begin{array}{c}0.030 \\
(0.470)\end{array}$ & $\begin{array}{c}0.469 \\
(0.335)\end{array}$ & $\begin{array}{c}0.289 \\
(0.259)\end{array}$ & $\begin{array}{l}-0.396 \\
(0.363)\end{array}$ & $\begin{array}{l}0.643 * \\
(0.385)\end{array}$ \\
\hline National Gender Quota & $\begin{array}{l}0.186 \\
(0.159)\end{array}$ & $\begin{array}{l}0.685^{*} \\
(0.374)\end{array}$ & $\begin{array}{c}0.017 \\
(0.185)\end{array}$ & $\begin{array}{c}0.115 \\
(0.090)\end{array}$ & $\begin{array}{l}-0.033 \\
(0.293)\end{array}$ & $\begin{array}{c}0.212 * * \\
(0.107)\end{array}$ & $\begin{array}{c}0.095 \\
(0.213)\end{array}$ & $\begin{array}{l}-0.002 \\
(0.268)\end{array}$ & $\begin{array}{c}0.143 \\
(0.247)\end{array}$ & $\begin{array}{c}0.112 \\
(0.148)\end{array}$ & $\begin{array}{c}-0.698 * * \\
(0.275)\end{array}$ & $\begin{array}{c}0.526 * * * \\
(0.185)\end{array}$ \\
\hline Closed List & $\begin{array}{l}-0.379 \\
(0.407)\end{array}$ & $\begin{array}{l}-0.720 \\
(0.696)\end{array}$ & $\begin{array}{l}-0.303 \\
(0.523)\end{array}$ & $\begin{array}{c}0.419 * * * \\
(0.162)\end{array}$ & $\begin{array}{c}0.249 \\
(0.521)\end{array}$ & $\begin{array}{l}0.468 * \\
(0.266)\end{array}$ & $\begin{array}{c}-0.790 * * \\
(0.361)\end{array}$ & $\begin{array}{l}-0.873 \\
(0.650)\end{array}$ & $\begin{array}{l}-0.690 \\
(0.543)\end{array}$ & $\begin{array}{l}0.509^{*} \\
(0.279)\end{array}$ & $\begin{array}{l}1.070^{*} \\
(0.632)\end{array}$ & $\begin{array}{c}0.114 \\
(0.365)\end{array}$ \\
\hline Disproportionality & $\begin{array}{l}-0.065 \\
(0.076)\end{array}$ & $\begin{array}{l}-0.221^{*} \\
(0.119)\end{array}$ & $\begin{array}{c}0.007 \\
(0.107)\end{array}$ & $\begin{array}{c}0.040 \\
(0.042)\end{array}$ & $\begin{array}{l}0.141^{*} \\
(0.080)\end{array}$ & $\begin{array}{l}-0.012 \\
(0.064)\end{array}$ & $\begin{array}{c}0.040 \\
(0.054)\end{array}$ & $\begin{array}{l}-0.046 \\
(0.061)\end{array}$ & $\begin{array}{c}0.139 \\
(0.087)\end{array}$ & $\begin{array}{l}-0.054 \\
(0.060)\end{array}$ & $\begin{array}{l}-0.053 \\
(0.124)\end{array}$ & $\begin{array}{l}-0.058 \\
(0.079)\end{array}$ \\
\hline \# of Districts & $\begin{array}{c}0.014 \\
(0.025)\end{array}$ & $\begin{array}{l}-0.003 \\
(0.041)\end{array}$ & $\begin{array}{c}0.021 \\
(0.041)\end{array}$ & $\begin{array}{c}-0.022 \\
(0.021)\end{array}$ & $\begin{array}{l}-0.021 \\
(0.040)\end{array}$ & $\begin{array}{c}-0.012 \\
(0.028)\end{array}$ & $\begin{array}{c}-0.064 * * \\
(0.032)\end{array}$ & $\begin{array}{l}-0.029 \\
(0.044)\end{array}$ & $\begin{array}{l}-0.096 \\
(0.059)\end{array}$ & $\begin{array}{c}-0.100 * * * \\
(0.038)\end{array}$ & $\begin{array}{c}-0.174 * * \\
(0.073)\end{array}$ & $\begin{array}{l}-0.086 \\
(0.056)\end{array}$ \\
\hline Women in Natl Parliament & $\begin{array}{l}-0.040 \\
(0.025)\end{array}$ & $\begin{array}{c}-0.128 * * * * \\
(0.047)\end{array}$ & $\begin{array}{c}-0.014 \\
(0.033)\end{array}$ & $\begin{array}{l}-0.003 \\
(0.013)\end{array}$ & $\begin{array}{c}0.012 \\
(0.032)\end{array}$ & $\begin{array}{l}-0.013 \\
(0.017)\end{array}$ & $\begin{array}{c}-0.033 \\
(0.021)\end{array}$ & $\begin{array}{l}-0.030 \\
(0.036)\end{array}$ & $\begin{array}{c}-0.036 \\
(0.026)\end{array}$ & $\begin{array}{l}-0.015 \\
(0.016)\end{array}$ & $\begin{array}{l}-0.020 \\
(0.035)\end{array}$ & $\begin{array}{l}-0.023 \\
(0.023)\end{array}$ \\
\hline Women with Degree & $\begin{array}{l}-0.006 \\
(0.008)\end{array}$ & $\begin{array}{c}-0.002 \\
(0.012)\end{array}$ & $\begin{array}{c}-0.009 \\
(0.010)\end{array}$ & $\begin{array}{c}0.005 \\
(0.004)\end{array}$ & $\begin{array}{c}0.006 \\
(0.008)\end{array}$ & $\begin{array}{c}0.003 \\
(0.007)\end{array}$ & $\begin{array}{c}0.015 * * \\
(0.006)\end{array}$ & $\begin{array}{c}0.019 * * \\
(0.007)\end{array}$ & $\begin{array}{c}0.012 \\
(0.009)\end{array}$ & $\begin{array}{c}0.021 * * * \\
(0.006)\end{array}$ & $\begin{array}{l}0.015^{*} \\
(0.009)\end{array}$ & $\begin{array}{c}0.023 * * \\
(0.009)\end{array}$ \\
\hline Religiosity & $\begin{array}{c}-0.014 \\
(0.011)\end{array}$ & $\begin{array}{c}-0.033 \\
(0.024)\end{array}$ & $\begin{array}{c}-0.007 \\
(0.017)\end{array}$ & $\begin{array}{c}0.003 \\
(0.006)\end{array}$ & $\begin{array}{c}0.008 \\
(0.016)\end{array}$ & $\begin{array}{c}0.001 \\
(0.007)\end{array}$ & $\begin{array}{c}-0.002 \\
(0.009)\end{array}$ & $\begin{array}{c}-0.024 * \\
(0.013)\end{array}$ & $\begin{array}{c}0.013 \\
(0.015)\end{array}$ & $\begin{array}{c}0.011 \\
(0.009)\end{array}$ & $\begin{array}{c}0.012 \\
(0.021)\end{array}$ & $\begin{array}{c}0.009 \\
(0.012)\end{array}$ \\
\hline Age & $\begin{array}{c}-0.033^{* * *} \\
(0.011)\end{array}$ & $\begin{array}{l}-0.038 \\
(0.026)\end{array}$ & $\begin{array}{c}-0.030 * * \\
(0.012)\end{array}$ & $\begin{array}{l}-0.001 \\
(0.011)\end{array}$ & $\begin{array}{c}-0.013 \\
(0.022)\end{array}$ & $\begin{array}{c}0.005 \\
(0.013)\end{array}$ & $\begin{array}{c}0.019 \\
(0.016)\end{array}$ & $\begin{array}{c}0.007 \\
(0.036)\end{array}$ & $\begin{array}{c}0.019 \\
(0.017)\end{array}$ & $\begin{array}{l}0.025^{*} \\
(0.014)\end{array}$ & $\begin{array}{c}0.071 * * \\
(0.029)\end{array}$ & $\begin{array}{c}0.010 \\
(0.018)\end{array}$ \\
\hline Radical Right & $\begin{array}{c}-0.210 \\
(0.527)\end{array}$ & $\begin{array}{c}-2.978 * * \\
(1.491)\end{array}$ & $\begin{array}{c}0.324 \\
(0.742)\end{array}$ & $\begin{array}{c}0.331 \\
(0.379)\end{array}$ & $\begin{array}{c}-0.551 \\
(0.871)\end{array}$ & $\begin{array}{c}0.143 \\
(0.507)\end{array}$ & $\begin{array}{c}0.215 \\
(0.782)\end{array}$ & $\begin{array}{l}-1.470 \\
(1.502)\end{array}$ & $\begin{array}{c}0.631 \\
(0.944)\end{array}$ & $\begin{array}{c}1.316 \\
(0.936)\end{array}$ & $\begin{array}{l}1.344^{*} \\
(0.766)\end{array}$ & $\begin{array}{c}0.769 \\
(1.069)\end{array}$ \\
\hline Conservative & $\begin{array}{l}-0.659 \\
(0.454)\end{array}$ & $\begin{array}{l}-3.726^{*} \\
(2.086)\end{array}$ & $\begin{array}{c}-0.042 \\
(0.569)\end{array}$ & $\begin{array}{c}0.608 \\
(0.442)\end{array}$ & & $\begin{array}{c}0.194 \\
(0.471)\end{array}$ & $\begin{array}{c}0.038 \\
(0.835)\end{array}$ & $\begin{array}{l}-1.055 \\
(1.338)\end{array}$ & $\begin{array}{c}0.204 \\
(0.973)\end{array}$ & $\begin{array}{c}1.100 \\
(0.828)\end{array}$ & & $\begin{array}{c}0.866 \\
(0.917)\end{array}$ \\
\hline Liberal & $\begin{array}{l}-0.514 \\
(0.486)\end{array}$ & $\begin{array}{c}-3.437 * * \\
(1.750)\end{array}$ & $\begin{array}{c}0.365 \\
(0.704)\end{array}$ & $\begin{array}{c}0.434 \\
(0.598)\end{array}$ & $\begin{array}{c}0.105 \\
(0.766)\end{array}$ & $\begin{array}{l}-0.103 \\
(0.657)\end{array}$ & $\begin{array}{c}1.478 * * \\
(0.744)\end{array}$ & $\begin{array}{c}0.236 \\
(1.094)\end{array}$ & $\begin{array}{l}1.785^{*} \\
(0.960)\end{array}$ & $\begin{array}{c}0.481 \\
(0.863)\end{array}$ & $\begin{array}{l}-1.459 \\
(1.072)\end{array}$ & $\begin{array}{c}0.642 \\
(0.969)\end{array}$ \\
\hline Christian Democrat & $\begin{array}{c}0.083 \\
(0.364)\end{array}$ & $\begin{array}{c}-1.833 \\
(1.758)\end{array}$ & $\begin{array}{c}0.414 \\
(0.571)\end{array}$ & $\begin{array}{c}0.604 \\
(0.471)\end{array}$ & $\begin{array}{l}-0.727 \\
(0.686)\end{array}$ & $\begin{array}{c}0.431 \\
(0.501)\end{array}$ & $\begin{array}{l}1.238^{*} \\
(0.742)\end{array}$ & $\begin{array}{c}0.685 \\
(1.065)\end{array}$ & $\begin{array}{c}1.331 \\
(0.986)\end{array}$ & $\begin{array}{c}0.737 \\
(0.845)\end{array}$ & $\begin{array}{c}0.248 \\
(0.815)\end{array}$ & $\begin{array}{c}0.278 \\
(0.928)\end{array}$ \\
\hline Socialist & $\begin{array}{c}-0.951 * * \\
(0.445)\end{array}$ & $\begin{array}{l}-2.938^{*} \\
(1.704)\end{array}$ & $\begin{array}{c}-0.385 \\
(0.457)\end{array}$ & $\begin{array}{c}0.508 \\
(0.462)\end{array}$ & $\begin{array}{l}-0.167 \\
(0.521)\end{array}$ & $\begin{array}{c}0.298 \\
(0.473)\end{array}$ & $\begin{array}{c}0.296 \\
(0.679)\end{array}$ & $\begin{array}{c}-0.427 \\
(1.241)\end{array}$ & $\begin{array}{c}0.305 \\
(0.992)\end{array}$ & $\begin{array}{l}-0.143 \\
(0.843)\end{array}$ & $\begin{array}{l}-1.353 \\
(0.852)\end{array}$ & $\begin{array}{c}-0.182 \\
(0.885)\end{array}$ \\
\hline Radical Left & $\begin{array}{c}-0.793 \\
(0.636)\end{array}$ & $\begin{array}{c}-2.657 \\
(1.794)\end{array}$ & $\begin{array}{c}-0.334 \\
(0.814)\end{array}$ & $\begin{array}{c}-0.165 \\
(0.571)\end{array}$ & $\begin{array}{l}-0.963 \\
(1.062)\end{array}$ & $\begin{array}{l}-0.400 \\
(0.649)\end{array}$ & $\begin{array}{c}0.052 \\
(0.846)\end{array}$ & & $\begin{array}{c}0.524 \\
(1.012)\end{array}$ & $\begin{array}{c}0.277 \\
(1.009)\end{array}$ & $\begin{array}{c}0.648 \\
(1.043)\end{array}$ & $\begin{array}{c}-0.926 \\
(1.317)\end{array}$ \\
\hline Green & $\begin{array}{c}-1.362 * * * \\
(0.502)\end{array}$ & $\begin{array}{c}-3.408 * * \\
(1.605)\end{array}$ & $\begin{array}{l}-0.930 \\
(0.649)\end{array}$ & $\begin{array}{l}-0.716 \\
(0.654)\end{array}$ & $\begin{array}{c}-1.125 \\
(0.778)\end{array}$ & $\begin{array}{c}-1.155^{*} \\
(0.622)\end{array}$ & $\begin{array}{c}0.252 \\
(0.850)\end{array}$ & $\begin{array}{c}-0.162 \\
(1.287)\end{array}$ & $\begin{array}{c}-0.291 \\
(1.033)\end{array}$ & $\begin{array}{c}0.671 \\
(0.894)\end{array}$ & $\begin{array}{c}0.158 \\
(0.832)\end{array}$ & $\begin{array}{l}-0.146 \\
(0.981)\end{array}$ \\
\hline Constant & $\begin{array}{c}3.479 \\
(2.205)\end{array}$ & $\begin{array}{c}9.274 * * \\
(3.996)\end{array}$ & $\begin{array}{c}1.952 \\
(2.545)\end{array}$ & $\begin{array}{c}-2.280 * * \\
(1.070)\end{array}$ & $\begin{array}{c}-2.153 \\
(2.180)\end{array}$ & $\begin{array}{l}-1.571 \\
(1.526)\end{array}$ & $\begin{array}{c}-3.652 * \\
(1.927)\end{array}$ & $\begin{array}{l}-1.642 \\
(2.523)\end{array}$ & $\begin{array}{c}-4.462 * \\
(2.520)\end{array}$ & $\begin{array}{c}-6.096^{* * *} \\
(1.851)\end{array}$ & $\begin{array}{l}-6.358^{*} \\
(3.292)\end{array}$ & $\begin{array}{c}-5.284 * * \\
(2.109)\end{array}$ \\
\hline Observations & 406 & 148 & 258 & 406 & 148 & 258 & 406 & 142 & 258 & 406 & 148 & 258 \\
\hline Pseudo $\mathrm{R}^{2}$ & 0.0471 & 0.152 & 0.0421 & 0.0249 & 0.0521 & 0.0393 & 0.113 & 0.133 & 0.131 & 0.0873 & 0.184 & 0.106 \\
\hline Wald $X^{2}(12)$ & 47.51 & 52.14 & 55.52 & 158.2 & 73.52 & 90.64 & 172.9 & 170.1 & 105.7 & 127.7 & 249.6 & 101.5 \\
\hline Prob $>X^{2}$ & 0.000 & 0.000 & 0.000 & 0.000 & 0.000 & 0.000 & 0.000 & 0.000 & 0.000 & 0.000 & 0.000 & 0.000 \\
\hline
\end{tabular}




\section{Robustness check of alternative measures}

In order to check the robustness of our analysis we used a series of alternation measure for our control variables. Recall that main analysis seeks to control for overall levels of gender equality in society using a measure of women's tertiary education as a percentage of men's education and religiosity as a the percentage of people attending church services once per month or more as answered by respondents to the European Values Survey (EVS 2015; WVS 2015). This is the percentage of respondents that answered answer to "Do you belong to a religious denomination?" which is variable V105 in the EVS. In terms of gender equality, we also tested the gap in the employment rate between men and women aged 20-64 and the gap in hourly wages between men and women as a percentage of average gross hourly earnings of men. These data are available from Eurostat at the following address:

http://ec.europa.eu/eurostat/web/equality/data/database. As the models below show, these alternative analyses confirm the conclusions of the paper and provided evidence in support $\mathrm{H} 1$ and $\mathrm{H} 2$. 
Table S3.1: Political Experience and National Gender Quotas: Pay Gap Control for Equality

\begin{tabular}{|c|c|c|c|c|c|c|c|c|c|c|c|c|}
\hline \multirow[t]{2}{*}{ VARIABLES } & \multicolumn{3}{|c|}{ National Party Office } & \multicolumn{3}{|c|}{ Former MPs } & \multicolumn{3}{|c|}{ Local Politicians } & \multicolumn{3}{|c|}{ Incumbents } \\
\hline & All & Female & Male & All & Female & Male & All & Female & Male & All & Female & Male \\
\hline National Gender Quota & $\begin{array}{c}0.329 \\
(0.207)\end{array}$ & $\begin{array}{c}0.098 \\
(0.345)\end{array}$ & $\begin{array}{c}0.405 * * \\
(0.195)\end{array}$ & $\begin{array}{c}0.245 \\
(0.238)\end{array}$ & $\begin{array}{c}0.508 * * \\
(0.203)\end{array}$ & $\begin{array}{c}0.168 \\
(0.293)\end{array}$ & $\begin{array}{c}0.011 \\
(0.176)\end{array}$ & $\begin{array}{c}0.193 \\
(0.152)\end{array}$ & $\begin{array}{l}-0.071 \\
(0.212)\end{array}$ & $\begin{array}{c}-0.414 * * \\
(0.207)\end{array}$ & $\begin{array}{c}-0.132 \\
(0.256)\end{array}$ & $\begin{array}{c}-0.589 * * * \\
(0.206)\end{array}$ \\
\hline Closed List & $\begin{array}{l}-0.079 \\
(0.359)\end{array}$ & $\begin{array}{c}0.370 \\
(0.630)\end{array}$ & $\begin{array}{l}-0.160 \\
(0.389)\end{array}$ & $\begin{array}{c}-1.255^{* * *} \\
(0.421)\end{array}$ & $\begin{array}{c}-2.399 * * * \\
(0.415)\end{array}$ & $\begin{array}{l}-0.712 \\
(0.461)\end{array}$ & $\begin{array}{c}0.565^{* *} \\
(0.251)\end{array}$ & $\begin{array}{c}0.047 \\
(0.208)\end{array}$ & $\begin{array}{c}0.843 * * \\
(0.340)\end{array}$ & $\begin{array}{c}0.888 * * \\
(0.357)\end{array}$ & $\begin{array}{c}0.683 \\
(0.453)\end{array}$ & $\begin{array}{c}0.965 * * * \\
(0.355)\end{array}$ \\
\hline Disproportionality & $\begin{array}{c}0.065 \\
(0.056)\end{array}$ & $\begin{array}{c}0.082 \\
(0.103)\end{array}$ & $\begin{array}{c}0.079 \\
(0.068)\end{array}$ & $\begin{array}{c}0.026 \\
(0.076)\end{array}$ & $\begin{array}{l}-0.012 \\
(0.060)\end{array}$ & $\begin{array}{c}0.062 \\
(0.102)\end{array}$ & $\begin{array}{c}0.091 \\
(0.059)\end{array}$ & $\begin{array}{c}0.010 \\
(0.043)\end{array}$ & $\begin{array}{c}0.126 \\
(0.079)\end{array}$ & $\begin{array}{c}0.062 \\
(0.063)\end{array}$ & $\begin{array}{l}-0.017 \\
(0.109)\end{array}$ & $\begin{array}{c}0.087 \\
(0.067)\end{array}$ \\
\hline Districts & $\begin{array}{c}-0.094 * * \\
(0.041)\end{array}$ & $\begin{array}{l}-0.095 \\
(0.066)\end{array}$ & $\begin{array}{c}-0.107 * * * \\
(0.040)\end{array}$ & $\begin{array}{c}-0.082 * \\
(0.049)\end{array}$ & $\begin{array}{c}-0.118^{*} \\
(0.066)\end{array}$ & $\begin{array}{c}-0.075^{*} \\
(0.045)\end{array}$ & $\begin{array}{c}0.026 \\
(0.023)\end{array}$ & $\begin{array}{c}0.013 \\
(0.023)\end{array}$ & $\begin{array}{c}0.033 \\
(0.027)\end{array}$ & $\begin{array}{l}-0.023 \\
(0.022)\end{array}$ & $\begin{array}{c}-0.079 * * \\
(0.036)\end{array}$ & $\begin{array}{c}0.009 \\
(0.022)\end{array}$ \\
\hline Women in Natl Parl & $\begin{array}{l}-0.030 \\
(0.018)\end{array}$ & $\begin{array}{l}-0.020 \\
(0.032)\end{array}$ & $\begin{array}{l}-0.029 \\
(0.019)\end{array}$ & $\begin{array}{l}-0.034 \\
(0.026)\end{array}$ & $\begin{array}{c}-0.044 * * \\
(0.022)\end{array}$ & $\begin{array}{l}-0.029 \\
(0.032)\end{array}$ & $\begin{array}{c}0.057 * * * \\
(0.018)\end{array}$ & $\begin{array}{c}0.029 * * \\
(0.014)\end{array}$ & $\begin{array}{c}0.070 * * * \\
(0.024)\end{array}$ & $\begin{array}{c}0.025 \\
(0.020)\end{array}$ & $\begin{array}{l}-0.019 \\
(0.030)\end{array}$ & $\begin{array}{c}0.041 * * \\
(0.019)\end{array}$ \\
\hline Gender Pay Gap & $\begin{array}{l}-0.016 \\
(0.026)\end{array}$ & $\begin{array}{l}-0.040 \\
(0.059)\end{array}$ & $\begin{array}{l}-0.006 \\
(0.025)\end{array}$ & $\begin{array}{l}-0.018 \\
(0.034)\end{array}$ & $\begin{array}{l}-0.011 \\
(0.037)\end{array}$ & $\begin{array}{l}-0.020 \\
(0.041)\end{array}$ & $\begin{array}{l}-0.003 \\
(0.030)\end{array}$ & $\begin{array}{c}0.058^{* *} \\
(0.026)\end{array}$ & $\begin{array}{l}-0.040 \\
(0.037)\end{array}$ & $\begin{array}{l}-0.017 \\
(0.029)\end{array}$ & $\begin{array}{l}-0.009 \\
(0.041)\end{array}$ & $\begin{array}{l}-0.027 \\
(0.030)\end{array}$ \\
\hline Religiosity & $\begin{array}{c}0.000 \\
(0.010)\end{array}$ & $\begin{array}{l}-0.014 \\
(0.018)\end{array}$ & $\begin{array}{c}0.008 \\
(0.010)\end{array}$ & $\begin{array}{c}0.011 \\
(0.012)\end{array}$ & $\begin{array}{l}-0.005 \\
(0.014)\end{array}$ & $\begin{array}{l}0.021^{*} \\
(0.012)\end{array}$ & $\begin{array}{l}-0.002 \\
(0.007)\end{array}$ & $\begin{array}{c}0.001 \\
(0.008)\end{array}$ & $\begin{array}{l}-0.004 \\
(0.009)\end{array}$ & $\begin{array}{l}-0.000 \\
(0.008)\end{array}$ & $\begin{array}{l}-0.005 \\
(0.011)\end{array}$ & $\begin{array}{l}-0.002 \\
(0.008)\end{array}$ \\
\hline Age & $\begin{array}{c}0.024 * * \\
(0.011)\end{array}$ & $\begin{array}{c}0.038 \\
(0.024)\end{array}$ & $\begin{array}{c}0.016 \\
(0.012)\end{array}$ & $\begin{array}{c}0.045^{* * * *} \\
(0.007)\end{array}$ & $\begin{array}{c}0.053 * * * \\
(0.014)\end{array}$ & $\begin{array}{c}0.043^{* * *} * \\
(0.010)\end{array}$ & $\begin{array}{c}0.021 * * * \\
(0.008)\end{array}$ & $\begin{array}{c}0.045^{* * * *} \\
(0.011)\end{array}$ & $\begin{array}{c}0.013 \\
(0.010)\end{array}$ & $\begin{array}{c}0.054 * * * \\
(0.006)\end{array}$ & $\begin{array}{c}0.058 * * * \\
(0.012)\end{array}$ & $\begin{array}{c}0.056 * * * \\
(0.009)\end{array}$ \\
\hline Constant & $\begin{array}{l}-1.799 \\
(1.126)\end{array}$ & $\begin{array}{l}-2.565 \\
(2.152)\end{array}$ & $\begin{array}{l}-1.612 \\
(1.218)\end{array}$ & $\begin{array}{l}-1.483 \\
(1.349)\end{array}$ & $\begin{array}{l}-0.679 \\
(1.045)\end{array}$ & $\begin{array}{l}-2.098 \\
(1.601)\end{array}$ & $\begin{array}{c}-3.902 * * * \\
(1.001)\end{array}$ & $\begin{array}{c}-4.422 * * * \\
(0.893)\end{array}$ & $\begin{array}{c}-3.616^{* *} \\
(1.453)\end{array}$ & $\begin{array}{c}-3.821 * * * \\
(1.012)\end{array}$ & $\begin{array}{l}-1.988 \\
(1.574)\end{array}$ & $\begin{array}{c}-4.457 * * * \\
(1.030)\end{array}$ \\
\hline Obser & 752 & 276 & 476 & 752 & 276 & 476 & 751 & 275 & 476 & 752 & 276 & 476 \\
\hline Pseudo $\mathrm{R}^{2}$ & 0.0417 & 0.0513 & 0.0461 & 0.128 & 0.196 & 0.115 & 0.0617 & 0.0753 & 0.0727 & 0.0802 & 0.0830 & 0.0959 \\
\hline Wald $X^{2}(12)$ & 38.34 & 8.832 & 20.33 & 59.53 & 65.59 & 28.88 & 58.22 & 68.63 & 40.36 & 169.2 & 40.99 & 146.4 \\
\hline Prob $>X^{2}$ & 0.000 & 0.357 & 0.009 & 0.000 & 0.000 & 0.000 & 0.000 & 0.000 & 0.000 & 0.000 & 0.000 & 0.000 \\
\hline
\end{tabular}


Table S3.2: Professional Experience and National Gender Quotas: Pay Gap Control for Equality

\begin{tabular}{|c|c|c|c|c|c|c|c|c|c|c|c|c|}
\hline \multirow[t]{2}{*}{ VARIABLES } & \multicolumn{3}{|c|}{ Legal } & \multicolumn{3}{|c|}{ Economics and Finance } & \multicolumn{3}{|c|}{ International Affairs } & \multicolumn{3}{|c|}{$\mathrm{PhD}$} \\
\hline & All & Female & Male & All & Female & Male & All & Female & Male & All & Female & Male \\
\hline \multirow[t]{2}{*}{ National Gender Quota } & $0.451^{* * *}$ & $0.704 * * *$ & $0.365 * * *$ & -0.041 & 0.226 & -0.160 & 0.252 & 0.253 & 0.254 & $0.426 * *$ & -0.023 & $0.627 * * *$ \\
\hline & $(0.117)$ & $(0.182)$ & $(0.133)$ & $(0.111)$ & $(0.172)$ & (0.099) & $(0.192)$ & $(0.242)$ & $(0.204)$ & $(0.187)$ & $(0.242)$ & $(0.242)$ \\
\hline \multirow[t]{2}{*}{ Closed List } & 0.266 & -0.007 & 0.330 & 0.099 & $-0.657 *$ & $0.446 * * *$ & $-0.832 * *$ & $-1.145 * *$ & $-0.638 * *$ & $-0.581 *$ & -0.319 & $-0.659 *$ \\
\hline & $(0.220)$ & $(0.364)$ & $(0.271)$ & $(0.188)$ & $(0.343)$ & $(0.170)$ & $(0.331)$ & $(0.513)$ & $(0.324)$ & $(0.303)$ & $(0.456)$ & $(0.357)$ \\
\hline \multirow[t]{2}{*}{ Disproportionality } & -0.043 & $-0.163 * *$ & 0.007 & -0.021 & 0.016 & -0.026 & 0.004 & -0.048 & 0.044 & $-0.196 * *$ & -0.112 & $-0.233 * *$ \\
\hline & $(0.043)$ & $(0.079)$ & $(0.053)$ & $(0.042)$ & $(0.074)$ & $(0.043)$ & $(0.055)$ & $(0.083)$ & $(0.058)$ & $(0.077)$ & $(0.131)$ & $(0.091)$ \\
\hline \multirow[t]{2}{*}{ Districts } & -0.021 & -0.020 & $-0.026^{*}$ & 0.002 & 0.027 & -0.002 & $-0.077 * *$ & -0.027 & $-0.106 * * *$ & -0.015 & -0.040 & -0.007 \\
\hline & $(0.014)$ & $(0.038)$ & $(0.015)$ & $(0.016)$ & $(0.034)$ & $(0.012)$ & $(0.039)$ & $(0.062)$ & $(0.037)$ & $(0.040)$ & $(0.048)$ & $(0.046)$ \\
\hline \multirow[t]{2}{*}{ Women in Natl Parl } & -0.018 & $-0.081 * * *$ & 0.011 & -0.010 & 0.000 & -0.008 & $-0.040 * *$ & -0.041 & $-0.040 *$ & $-0.060 * * *$ & -0.050 & $-0.064 * * *$ \\
\hline & $(0.016)$ & $(0.021)$ & $(0.023)$ & $(0.013)$ & $(0.024)$ & $(0.014)$ & $(0.020)$ & $(0.028)$ & $(0.022)$ & $(0.017)$ & $(0.037)$ & $(0.024)$ \\
\hline \multirow[t]{2}{*}{ Gender Pay Gap } & 0.002 & -0.037 & 0.026 & 0.020 & $0.059^{*}$ & 0.007 & -0.043 & $-0.065^{*}$ & -0.031 & $0.057 * *$ & 0.063 & 0.057 \\
\hline & $(0.024)$ & $(0.036)$ & $(0.030)$ & $(0.019)$ & $(0.033)$ & $(0.019)$ & $(0.033)$ & $(0.038)$ & $(0.034)$ & $(0.025)$ & $(0.041)$ & $(0.038)$ \\
\hline \multirow[t]{2}{*}{ Religiosity } & -0.004 & -0.022 & 0.005 & 0.004 & 0.006 & 0.004 & $-0.017 *$ & $-0.039 * *$ & -0.003 & -0.005 & 0.004 & -0.009 \\
\hline & $(0.007)$ & $(0.016)$ & $(0.009)$ & $(0.004)$ & $(0.009)$ & $(0.006)$ & $(0.010)$ & $(0.017)$ & $(0.012)$ & $(0.007)$ & $(0.018)$ & $(0.010)$ \\
\hline \multirow[t]{2}{*}{ Age } & $-0.022 * *$ & -0.002 & $-0.032 * * *$ & -0.002 & -0.014 & 0.002 & $0.026 * * *$ & 0.018 & $0.028 * * *$ & 0.010 & 0.016 & 0.006 \\
\hline & $(0.010)$ & $(0.018)$ & $(0.010)$ & $(0.008)$ & $(0.014)$ & $(0.008)$ & $(0.008)$ & (0.019) & $(0.007)$ & $(0.008)$ & $(0.022)$ & $(0.008)$ \\
\hline \multirow[t]{2}{*}{ Constant } & 0.363 & $2.771 * *$ & -0.660 & -0.923 & -1.536 & -1.083 & 0.331 & 1.910 & -0.536 & 0.210 & -1.186 & 0.855 \\
\hline & $(0.956)$ & $(1.259)$ & (1.494) & $(0.743)$ & (1.614) & $(0.780)$ & $(1.292)$ & (2.119) & $(1.286)$ & $(0.979)$ & $(2.394)$ & (1.204) \\
\hline Observations & 745 & 273 & 472 & 745 & 273 & 472 & 745 & 273 & 472 & 745 & 273 & 472 \\
\hline Pseudo $\mathrm{R}^{2}$ & 0.0371 & 0.0848 & 0.0430 & 0.00443 & 0.0181 & 0.0124 & 0.0599 & 0.0670 & 0.0679 & 0.0374 & 0.0426 & 0.0448 \\
\hline Wald $X^{2}(12)$ & 98.96 & 84.11 & 140 & 10.92 & 6.848 & 38.76 & 47.79 & 39.46 & 52.32 & 45 & 15.63 & 13.39 \\
\hline Prob $>X^{2}$ & 0.000 & 0.000 & 0.000 & 0.206 & 0.553 & 0.000 & 0.000 & 0.000 & 0.000 & 0.000 & 0.0480 & 0.0990 \\
\hline
\end{tabular}


Table S3.3: Political Experience and National Gender Quotas: Employment Gap Control for Equality

\begin{tabular}{|c|c|c|c|c|c|c|c|c|c|c|c|c|}
\hline \multirow{3}{*}{ VARIABLES } & \multicolumn{3}{|c|}{ (1) } & \multicolumn{3}{|c|}{$(2)$} & \multicolumn{3}{|c|}{ (3) } & \multicolumn{3}{|c|}{ (4) } \\
\hline & \multicolumn{3}{|c|}{ National Party Office } & \multicolumn{3}{|c|}{ Former MPs } & \multicolumn{3}{|c|}{ Local Politicians } & \multicolumn{3}{|c|}{ Incumbent } \\
\hline & All & Female & Male & All & Female & Male & All & Female & Male & All & Female & Male \\
\hline National Gender Quota & $\begin{array}{c}0.489 * * \\
(0.195)\end{array}$ & $\begin{array}{c}0.347 \\
(0.323)\end{array}$ & $\begin{array}{c}0.529 * * * \\
(0.180)\end{array}$ & $\begin{array}{c}0.427 * * * \\
(0.150)\end{array}$ & $\begin{array}{c}0.642 * * * \\
(0.202)\end{array}$ & $\begin{array}{c}0.376^{* *} \\
(0.157)\end{array}$ & $\begin{array}{c}0.013 \\
(0.149)\end{array}$ & $\begin{array}{c}0.049 \\
(0.121)\end{array}$ & $\begin{array}{c}0.025 \\
(0.197)\end{array}$ & $\begin{array}{c}-0.301 * * \\
(0.138)\end{array}$ & $\begin{array}{l}-0.010 \\
(0.163)\end{array}$ & $\begin{array}{c}-0.460 * * * \\
(0.148)\end{array}$ \\
\hline Closed List & $\begin{array}{l}-0.149 \\
(0.274)\end{array}$ & $\begin{array}{c}0.323 \\
(0.534)\end{array}$ & $\begin{array}{l}-0.229 \\
(0.299)\end{array}$ & $\begin{array}{c}-1.302 * * * \\
(0.270)\end{array}$ & $\begin{array}{c}-2.340 * * * \\
(0.299)\end{array}$ & $\begin{array}{c}-0.831 * * * \\
(0.289)\end{array}$ & $\begin{array}{c}0.548 * * \\
(0.215)\end{array}$ & $\begin{array}{c}0.298 \\
(0.262)\end{array}$ & $\begin{array}{c}0.642 * * \\
(0.285)\end{array}$ & $\begin{array}{c}0.877 * * * \\
(0.314)\end{array}$ & $\begin{array}{c}0.777 * * \\
(0.365)\end{array}$ & $\begin{array}{c}0.887 * * * \\
(0.322)\end{array}$ \\
\hline Disproportionality & $\begin{array}{c}0.053 \\
(0.044)\end{array}$ & $\begin{array}{c}0.076 \\
(0.103)\end{array}$ & $\begin{array}{c}0.070 \\
(0.059)\end{array}$ & $\begin{array}{c}0.032 \\
(0.045)\end{array}$ & $\begin{array}{c}-0.003 \\
(0.054)\end{array}$ & $\begin{array}{c}0.060 \\
(0.063)\end{array}$ & $\begin{array}{c}0.091 \\
(0.056)\end{array}$ & $\begin{array}{c}0.018 \\
(0.052)\end{array}$ & $\begin{array}{c}0.117 \\
(0.074)\end{array}$ & $\begin{array}{c}0.061 \\
(0.057)\end{array}$ & $\begin{array}{l}-0.017 \\
(0.089)\end{array}$ & $\begin{array}{c}0.082 \\
(0.068)\end{array}$ \\
\hline Districts & $\begin{array}{c}-0.118 * * * \\
(0.039)\end{array}$ & $\begin{array}{l}-0.111 \\
(0.071)\end{array}$ & $\begin{array}{c}-0.130 * * * \\
(0.036)\end{array}$ & $\begin{array}{c}-0.131 * * * \\
(0.024)\end{array}$ & $\begin{array}{c}-0.159 * * * \\
(0.048)\end{array}$ & $\begin{array}{c}-0.126 * * * \\
(0.023)\end{array}$ & $\begin{array}{c}0.027 \\
(0.024)\end{array}$ & $\begin{array}{l}0.010 \\
(0.024)\end{array}$ & $\begin{array}{c}0.033 \\
(0.030)\end{array}$ & $\begin{array}{c}-0.042 * * \\
(0.018)\end{array}$ & $\begin{array}{c}-0.102 * * * \\
(0.031)\end{array}$ & $\begin{array}{l}-0.010 \\
(0.019)\end{array}$ \\
\hline Women in Natl Parliament & $\begin{array}{c}-0.030^{*} \\
(0.015)\end{array}$ & $\begin{array}{l}-0.016 \\
(0.029)\end{array}$ & $\begin{array}{c}-0.029^{*} \\
(0.016)\end{array}$ & $\begin{array}{l}-0.030 \\
(0.020)\end{array}$ & $\begin{array}{c}-0.040^{*} \\
(0.021)\end{array}$ & $\begin{array}{l}-0.025 \\
(0.024)\end{array}$ & $\begin{array}{c}0.057 * * * \\
(0.017)\end{array}$ & $\begin{array}{l}0.029 * \\
(0.017)\end{array}$ & $\begin{array}{c}0.067 * * * \\
(0.025)\end{array}$ & $\begin{array}{l}0.028^{*} \\
(0.015)\end{array}$ & $\begin{array}{l}-0.016 \\
(0.024)\end{array}$ & $\begin{array}{c}0.043^{* * *} * \\
(0.015)\end{array}$ \\
\hline Employment Gap & $\begin{array}{c}-0.058 * * \\
(0.024)\end{array}$ & $\begin{array}{c}-0.088^{*} \\
(0.049)\end{array}$ & $\begin{array}{c}-0.049 * * \\
(0.023)\end{array}$ & $\begin{array}{c}-0.094 * * * \\
(0.018)\end{array}$ & $\begin{array}{c}-0.066 * * \\
(0.028)\end{array}$ & $\begin{array}{c}-0.106 * * * \\
(0.018)\end{array}$ & $\begin{array}{c}0.003 \\
(0.021)\end{array}$ & $\begin{array}{c}0.004 \\
(0.018)\end{array}$ & $\begin{array}{c}0.004 \\
(0.029)\end{array}$ & $\begin{array}{c}-0.052 * * * \\
(0.017)\end{array}$ & $\begin{array}{c}-0.066 * * * \\
(0.021)\end{array}$ & $\begin{array}{c}-0.048 * * * \\
(0.016)\end{array}$ \\
\hline Religiosity & $\begin{array}{c}0.011 \\
(0.008)\end{array}$ & $\begin{array}{c}0.009 \\
(0.019)\end{array}$ & $\begin{array}{l}0.015^{*} \\
(0.009)\end{array}$ & $\begin{array}{c}0.031 * * * \\
(0.008)\end{array}$ & $\begin{array}{l}0.015^{*} \\
(0.008)\end{array}$ & $\begin{array}{c}0.039 * * * \\
(0.009)\end{array}$ & $\begin{array}{c}-0.002 \\
(0.007)\end{array}$ & $\begin{array}{c}-0.008 \\
(0.006)\end{array}$ & $\begin{array}{c}0.001 \\
(0.010)\end{array}$ & $\begin{array}{c}0.011 \\
(0.010)\end{array}$ & $\begin{array}{c}0.012 \\
(0.013)\end{array}$ & $\begin{array}{c}0.008 \\
(0.010)\end{array}$ \\
\hline Age & $\begin{array}{c}0.023 * * \\
(0.011)\end{array}$ & $\begin{array}{c}0.036 \\
(0.025)\end{array}$ & $\begin{array}{c}0.015 \\
(0.012)\end{array}$ & $\begin{array}{c}0.044 * * * \\
(0.008)\end{array}$ & $\begin{array}{c}0.050 * * * \\
(0.014)\end{array}$ & $\begin{array}{c}0.043 * * * \\
(0.010)\end{array}$ & $\begin{array}{c}0.021 * * * \\
(0.007)\end{array}$ & $\begin{array}{c}0.046 * * * \\
(0.012)\end{array}$ & $\begin{array}{c}0.011 \\
(0.010)\end{array}$ & $\begin{array}{c}0.053 * * * \\
(0.006)\end{array}$ & $\begin{array}{c}0.057 * * * \\
(0.012)\end{array}$ & $\begin{array}{c}0.055^{* * *} * \\
(0.009)\end{array}$ \\
\hline Constant & $\begin{array}{l}-1.356 \\
(0.987)\end{array}$ & $\begin{array}{l}-2.669 \\
(1.915)\end{array}$ & $\begin{array}{l}-1.091 \\
(1.228)\end{array}$ & $\begin{array}{l}-1.017 \\
(1.123)\end{array}$ & $\begin{array}{l}-0.465 \\
(0.971)\end{array}$ & $\begin{array}{l}-1.440 \\
(1.454)\end{array}$ & $\begin{array}{c}-3.972 * * * \\
(1.194)\end{array}$ & $\begin{array}{c}-3.433 * * * \\
(1.175)\end{array}$ & $\begin{array}{c}-4.146 * * \\
(1.681)\end{array}$ & $\begin{array}{c}-3.657 * * * \\
(0.913)\end{array}$ & $\begin{array}{l}-1.707 \\
(1.450)\end{array}$ & $\begin{array}{c}-4.382 * * * \\
(1.132)\end{array}$ \\
\hline Observations & 752 & 276 & 476 & 752 & 276 & 476 & 751 & 275 & 476 & 752 & 276 & 476 \\
\hline Pseudo $\mathrm{R}^{2}$ & 0.0574 & 0.0746 & 0.0577 & 0.174 & 0.218 & 0.169 & 0.0617 & 0.0669 & 0.0688 & 0.0933 & 0.105 & 0.105 \\
\hline Wald $X^{2}(12)$ & 18.58 & 5.144 & 24.83 & 102.6 & 96.78 & 151.9 & 67.98 & 48.04 & 40.83 & 291.5 & 66.33 & 206.8 \\
\hline Prob $>X^{2}$ & 0.0173 & 0.742 & 0.002 & 0.000 & 0.000 & 0.000 & 0.000 & 0.000 & 0.000 & 0.000 & 0.000 & 0.000 \\
\hline
\end{tabular}


Table S3.4: Political Experience and National Gender Quotas: Employment Gap Control for Equality

\begin{tabular}{|c|c|c|c|c|c|c|c|c|c|c|c|c|}
\hline \multirow{3}{*}{ VARIABLES } & \multicolumn{3}{|c|}{$(1)$} & \multicolumn{3}{|c|}{ (2) } & \multicolumn{3}{|c|}{ (3) } & \multicolumn{3}{|c|}{ (4) } \\
\hline & \multicolumn{3}{|c|}{ legal } & \multicolumn{3}{|c|}{ Economics and Finance } & \multicolumn{3}{|c|}{ International } & \multicolumn{3}{|c|}{$\mathrm{PhD}$} \\
\hline & All & Female & Male & All & Female & Male & All & Female & Male & All & Female & Male \\
\hline National Gender Quota & $\begin{array}{c}0.380 * * * \\
(0.081)\end{array}$ & $\begin{array}{c}0.723 * * * \\
(0.188)\end{array}$ & $\begin{array}{c}0.243 * * * \\
(0.080)\end{array}$ & $\begin{array}{c}-0.043 \\
(0.061)\end{array}$ & $\begin{array}{c}0.141 \\
(0.115)\end{array}$ & $\begin{array}{c}-0.137 * * \\
(0.060)\end{array}$ & $\begin{array}{c}0.453 * * * \\
(0.119)\end{array}$ & $\begin{array}{c}0.578 * * * \\
(0.125)\end{array}$ & $\begin{array}{c}0.380 * * \\
(0.168)\end{array}$ & $\begin{array}{c}0.337 * * \\
(0.164)\end{array}$ & $\begin{array}{l}-0.204 \\
(0.220)\end{array}$ & $\begin{array}{c}0.615 * * * \\
(0.217)\end{array}$ \\
\hline Closed List & $\begin{array}{c}0.290 \\
(0.181)\end{array}$ & $\begin{array}{l}-0.156 \\
(0.380)\end{array}$ & $\begin{array}{c}0.461 * * \\
(0.232)\end{array}$ & $\begin{array}{c}0.200 \\
(0.134)\end{array}$ & $\begin{array}{l}-0.323 \\
(0.286)\end{array}$ & $\begin{array}{c}0.468 * * * \\
(0.138)\end{array}$ & $\begin{array}{c}-0.947 * * * \\
(0.262)\end{array}$ & $\begin{array}{c}-1.197 * * * \\
(0.310)\end{array}$ & $\begin{array}{c}-0.744 * * \\
(0.310)\end{array}$ & $\begin{array}{c}-0.393 \\
(0.295)\end{array}$ & $\begin{array}{l}-0.148 \\
(0.508)\end{array}$ & $\begin{array}{l}-0.506 \\
(0.335)\end{array}$ \\
\hline Disproportionality & $\begin{array}{l}-0.038 \\
(0.038)\end{array}$ & $\begin{array}{c}-0.191 * * \\
(0.086)\end{array}$ & $\begin{array}{c}0.022 \\
(0.053)\end{array}$ & $\begin{array}{l}-0.008 \\
(0.030)\end{array}$ & $\begin{array}{c}0.026 \\
(0.048)\end{array}$ & $\begin{array}{l}-0.021 \\
(0.039)\end{array}$ & $\begin{array}{l}-0.008 \\
(0.054)\end{array}$ & $\begin{array}{l}-0.052 \\
(0.073)\end{array}$ & $\begin{array}{c}0.031 \\
(0.060)\end{array}$ & $\begin{array}{c}-0.151 * * \\
(0.059)\end{array}$ & $\begin{array}{l}-0.084 \\
(0.115)\end{array}$ & $\begin{array}{c}-0.195^{* *} \\
(0.078)\end{array}$ \\
\hline Districts & $\begin{array}{l}-0.010 \\
(0.016)\end{array}$ & $\begin{array}{c}0.002 \\
(0.037)\end{array}$ & $\begin{array}{l}-0.016 \\
(0.021)\end{array}$ & $\begin{array}{l}-0.010 \\
(0.011)\end{array}$ & $\begin{array}{c}0.005 \\
(0.021)\end{array}$ & $\begin{array}{l}-0.011 \\
(0.013)\end{array}$ & $\begin{array}{c}-0.102 * * * \\
(0.032)\end{array}$ & $\begin{array}{c}-0.061 * * \\
(0.028)\end{array}$ & $\begin{array}{c}-0.120 * * * \\
(0.043)\end{array}$ & $\begin{array}{l}-0.036 \\
(0.032)\end{array}$ & $\begin{array}{l}-0.040 \\
(0.055)\end{array}$ & $\begin{array}{l}-0.042 \\
(0.038)\end{array}$ \\
\hline Women in Natl Parliament & $\begin{array}{l}-0.020 \\
(0.014)\end{array}$ & $\begin{array}{c}-0.093 * * * \\
(0.025)\end{array}$ & $\begin{array}{c}0.012 \\
(0.021)\end{array}$ & $\begin{array}{l}-0.006 \\
(0.009)\end{array}$ & $\begin{array}{l}-0.000 \\
(0.019)\end{array}$ & $\begin{array}{l}-0.005 \\
(0.012)\end{array}$ & $\begin{array}{c}-0.041 * * \\
(0.016)\end{array}$ & $\begin{array}{l}-0.036 \\
(0.023)\end{array}$ & $\begin{array}{c}-0.040 * * \\
(0.019)\end{array}$ & $\begin{array}{c}-0.050 * * * \\
(0.014)\end{array}$ & $\begin{array}{l}-0.047 \\
(0.034)\end{array}$ & $\begin{array}{c}-0.053 * * * \\
(0.018)\end{array}$ \\
\hline Employment Gap & $\begin{array}{c}0.033 * * * \\
(0.011)\end{array}$ & $\begin{array}{l}0.043^{*} \\
(0.026)\end{array}$ & $\begin{array}{c}0.030 * * \\
(0.015)\end{array}$ & $\begin{array}{c}-0.034 * * * \\
(0.011)\end{array}$ & $\begin{array}{c}-0.046 * * \\
(0.020)\end{array}$ & $\begin{array}{c}-0.027 * * * \\
(0.010)\end{array}$ & $\begin{array}{c}-0.054 * * * \\
(0.020)\end{array}$ & $\begin{array}{c}-0.097 * * * \\
(0.026)\end{array}$ & $\begin{array}{l}-0.031 \\
(0.026)\end{array}$ & $\begin{array}{l}-0.027 \\
(0.019)\end{array}$ & $\begin{array}{c}0.021 \\
(0.033)\end{array}$ & $\begin{array}{c}-0.056 * * \\
(0.025)\end{array}$ \\
\hline Religiosity & $\begin{array}{l}-0.009 \\
(0.006)\end{array}$ & $\begin{array}{c}-0.028^{* *} \\
(0.012)\end{array}$ & $\begin{array}{l}-0.002 \\
(0.009)\end{array}$ & $\begin{array}{c}0.007 \\
(0.005)\end{array}$ & $\begin{array}{c}0.008 \\
(0.009)\end{array}$ & $\begin{array}{c}0.007 \\
(0.006)\end{array}$ & $\begin{array}{c}-0.001 \\
(0.010)\end{array}$ & $\begin{array}{l}-0.007 \\
(0.010)\end{array}$ & $\begin{array}{c}0.005 \\
(0.013)\end{array}$ & $\begin{array}{l}-0.006 \\
(0.008)\end{array}$ & $\begin{array}{l}-0.010 \\
(0.023)\end{array}$ & $\begin{array}{c}-0.008 \\
(0.011)\end{array}$ \\
\hline Age & $\begin{array}{c}-0.021 * * \\
(0.010)\end{array}$ & $\begin{array}{l}-0.000 \\
(0.017)\end{array}$ & $\begin{array}{c}-0.031 * * * \\
(0.010)\end{array}$ & $\begin{array}{l}-0.003 \\
(0.008)\end{array}$ & $\begin{array}{l}-0.016 \\
(0.015)\end{array}$ & $\begin{array}{c}0.002 \\
(0.008)\end{array}$ & $\begin{array}{c}0.023 * * * \\
(0.009)\end{array}$ & $\begin{array}{c}0.013 \\
(0.021)\end{array}$ & $\begin{array}{c}0.026 * * * \\
(0.007)\end{array}$ & $\begin{array}{c}0.012 \\
(0.008)\end{array}$ & $\begin{array}{c}0.019 \\
(0.021)\end{array}$ & $\begin{array}{c}0.009 \\
(0.009)\end{array}$ \\
\hline Constant & $\begin{array}{c}0.019 \\
(0.951)\end{array}$ & $\begin{array}{c}2.127 \\
(1.522)\end{array}$ & $\begin{array}{c}-0.748 \\
(1.374)\end{array}$ & $\begin{array}{l}-0.411 \\
(0.615)\end{array}$ & $\begin{array}{c}0.013 \\
(1.149)\end{array}$ & $\begin{array}{l}-0.763 \\
(0.763)\end{array}$ & $\begin{array}{c}0.273 \\
(1.135)\end{array}$ & $\begin{array}{c}1.529 \\
(1.796)\end{array}$ & $\begin{array}{c}-0.576 \\
(1.183)\end{array}$ & $\begin{array}{c}0.895 \\
(0.951)\end{array}$ & $\begin{array}{l}-0.464 \\
(2.155)\end{array}$ & $\begin{array}{c}1.847 \\
(1.138)\end{array}$ \\
\hline Observations & 745 & 273 & 472 & 745 & 273 & 472 & 745 & 273 & 472 & 745 & 273 & 472 \\
\hline Pseudo $\mathrm{R}^{2}$ & 0.0427 & 0.0910 & 0.0456 & 0.00945 & 0.0208 & 0.0159 & 0.0696 & 0.0965 & 0.0700 & 0.0330 & 0.0340 & 0.0517 \\
\hline Wald $X^{2}(12)$ & 112.5 & 31.09 & 80.03 & 45.20 & 12.46 & 84.59 & 61.71 & 57.11 & 60.85 & 32.43 & 8.734 & 27.44 \\
\hline Prob $>X^{2}$ & 0.000 & 0.000 & 0.000 & 0.000 & 0.132 & 0.000 & 0.000 & 0.000 & 0.000 & 0.000 & 0.365 & 0.000 \\
\hline
\end{tabular}


Table S3.5: Political Experience and National Gender Quotas: Belonging to Religiosity Measure

\begin{tabular}{|c|c|c|c|c|c|c|c|c|c|c|c|c|}
\hline \multirow[t]{2}{*}{ VARIABLES } & \multicolumn{3}{|c|}{$\begin{array}{c}\text { (1) } \\
\text { National Party Office }\end{array}$} & \multicolumn{3}{|c|}{$\begin{array}{c}(2) \\
\text { Former MPs }\end{array}$} & \multicolumn{3}{|c|}{$\begin{array}{c}\text { (3) } \\
\text { Local Politicians }\end{array}$} & \multicolumn{3}{|c|}{$\begin{array}{c}\text { (4) } \\
\text { Incumbents }\end{array}$} \\
\hline & All & Female & Male & All & Female & Male & All & Female & Male & All & Female & Male \\
\hline National Gender Quota & $\begin{array}{l}0.349^{*} \\
(0.207)\end{array}$ & $\begin{array}{c}0.209 \\
(0.320)\end{array}$ & $\begin{array}{c}0.404 * * \\
(0.176)\end{array}$ & $\begin{array}{c}0.208 \\
(0.142)\end{array}$ & $\begin{array}{c}0.484 * * * \\
(0.132)\end{array}$ & $\begin{array}{c}0.139 \\
(0.184)\end{array}$ & $\begin{array}{c}0.012 \\
(0.138)\end{array}$ & $\begin{array}{c}0.045 \\
(0.119)\end{array}$ & $\begin{array}{c}0.028 \\
(0.183)\end{array}$ & $\begin{array}{c}-0.384 * * \\
(0.185)\end{array}$ & $\begin{array}{l}-0.117 \\
(0.205)\end{array}$ & $\begin{array}{c}-0.538 * * * \\
(0.186)\end{array}$ \\
\hline Closed List & $\begin{array}{c}0.046 \\
(0.373)\end{array}$ & $\begin{array}{c}0.077 \\
(0.549)\end{array}$ & $\begin{array}{c}0.074 \\
(0.407)\end{array}$ & $\begin{array}{c}-0.613 * * \\
(0.306)\end{array}$ & $\begin{array}{c}-1.714 * * * \\
(0.215)\end{array}$ & $\begin{array}{l}-0.145 \\
(0.392)\end{array}$ & $\begin{array}{c}0.597 * * * \\
(0.226)\end{array}$ & $\begin{array}{c}0.373 \\
(0.257)\end{array}$ & $\begin{array}{c}0.671 * * \\
(0.304)\end{array}$ & $\begin{array}{c}0.893 * * \\
(0.417)\end{array}$ & $\begin{array}{c}0.697 \\
(0.427)\end{array}$ & $\begin{array}{c}0.962 * * \\
(0.429)\end{array}$ \\
\hline Disproportionality & $\begin{array}{c}0.077 \\
(0.055)\end{array}$ & $\begin{array}{c}0.061 \\
(0.109)\end{array}$ & $\begin{array}{c}0.103 \\
(0.063)\end{array}$ & $\begin{array}{l}0.102 * * \\
(0.051)\end{array}$ & $\begin{array}{l}0.071^{*} \\
(0.038)\end{array}$ & $\begin{array}{c}0.123 \\
(0.079)\end{array}$ & $\begin{array}{l}0.095^{*} \\
(0.054)\end{array}$ & $\begin{array}{l}0.025 \\
(0.053)\end{array}$ & $\begin{array}{l}0.119 * \\
(0.072)\end{array}$ & $\begin{array}{c}0.063 \\
(0.072)\end{array}$ & $\begin{array}{l}-0.014 \\
(0.110)\end{array}$ & $\begin{array}{c}0.088 \\
(0.077)\end{array}$ \\
\hline \# of Districts & $\begin{array}{c}-0.096 * * \\
(0.039)\end{array}$ & $\begin{array}{l}-0.098 \\
(0.068)\end{array}$ & $\begin{array}{c}-0.115^{* * *} \\
(0.035)\end{array}$ & $\begin{array}{c}-0.115^{* * * *} \\
(0.019)\end{array}$ & $\begin{array}{c}-0.174 * * * \\
(0.036)\end{array}$ & $\begin{array}{c}-0.099 * * * \\
(0.024)\end{array}$ & $\begin{array}{c}0.025 \\
(0.023)\end{array}$ & $\begin{array}{c}0.009 \\
(0.023)\end{array}$ & $\begin{array}{c}0.031 \\
(0.028)\end{array}$ & $\begin{array}{l}-0.023 \\
(0.021)\end{array}$ & $\begin{array}{c}-0.079 * * \\
(0.034)\end{array}$ & $\begin{array}{c}0.007 \\
(0.022)\end{array}$ \\
\hline Women in Natl Parliament & $\begin{array}{l}-0.022 \\
(0.021)\end{array}$ & $\begin{array}{l}-0.028 \\
(0.033)\end{array}$ & $\begin{array}{l}-0.016 \\
(0.023)\end{array}$ & $\begin{array}{l}-0.000 \\
(0.018)\end{array}$ & $\begin{array}{l}-0.015 \\
(0.021)\end{array}$ & $\begin{array}{c}0.003 \\
(0.024)\end{array}$ & $\begin{array}{c}0.059 * * * \\
(0.017)\end{array}$ & $\begin{array}{l}0.032^{*} \\
(0.019)\end{array}$ & $\begin{array}{c}0.068 * * * \\
(0.024)\end{array}$ & $\begin{array}{c}0.027 \\
(0.022)\end{array}$ & $\begin{array}{l}-0.017 \\
(0.030)\end{array}$ & $\begin{array}{l}0.044 * * \\
(0.021)\end{array}$ \\
\hline Women with Degree & $\begin{array}{c}0.007 \\
(0.007)\end{array}$ & $\begin{array}{l}-0.005 \\
(0.009)\end{array}$ & $\begin{array}{c}0.012 \\
(0.008)\end{array}$ & $\begin{array}{c}0.032 * * * \\
(0.005)\end{array}$ & $\begin{array}{c}0.035 * * * \\
(0.008)\end{array}$ & $\begin{array}{c}0.030 * * * \\
(0.007)\end{array}$ & $\begin{array}{c}0.002 \\
(0.004)\end{array}$ & $\begin{array}{c}0.003 \\
(0.005)\end{array}$ & $\begin{array}{c}0.001 \\
(0.006)\end{array}$ & $\begin{array}{c}0.003 \\
(0.005)\end{array}$ & $\begin{array}{c}0.002 \\
(0.006)\end{array}$ & $\begin{array}{c}0.004 \\
(0.005)\end{array}$ \\
\hline Religiosity & $\begin{array}{c}0.004 \\
(0.008)\end{array}$ & $\begin{array}{l}-0.010 \\
(0.016)\end{array}$ & $\begin{array}{c}0.009 \\
(0.009)\end{array}$ & $\begin{array}{c}0.017 * * * \\
(0.006)\end{array}$ & $\begin{array}{c}0.005 \\
(0.008)\end{array}$ & $\begin{array}{c}0.024 * * * \\
(0.008)\end{array}$ & $\begin{array}{l}-0.001 \\
(0.008)\end{array}$ & $\begin{array}{l}-0.007 \\
(0.007)\end{array}$ & $\begin{array}{c}0.001 \\
(0.012)\end{array}$ & $\begin{array}{c}0.002 \\
(0.010)\end{array}$ & $\begin{array}{l}-0.003 \\
(0.013)\end{array}$ & $\begin{array}{c}0.001 \\
(0.010)\end{array}$ \\
\hline Age & $\begin{array}{c}0.023 * * \\
(0.011)\end{array}$ & $\begin{array}{c}0.039 \\
(0.024)\end{array}$ & $\begin{array}{c}0.015 \\
(0.013)\end{array}$ & $\begin{array}{c}0.045 * * * \\
(0.007)\end{array}$ & $\begin{array}{c}0.052 * * * \\
(0.015)\end{array}$ & $\begin{array}{c}0.043 * * * \\
(0.011)\end{array}$ & $\begin{array}{c}0.021 * * * \\
(0.007)\end{array}$ & $\begin{array}{c}0.045 * * * \\
(0.012)\end{array}$ & $\begin{array}{c}0.011 \\
(0.010)\end{array}$ & $\begin{array}{c}0.053 * * * \\
(0.006)\end{array}$ & $\begin{array}{c}0.058 * * * \\
(0.012)\end{array}$ & $\begin{array}{c}0.055^{* * * *} \\
(0.009)\end{array}$ \\
\hline Constant & $\begin{array}{c}-3.530 * \\
(1.904)\end{array}$ & $\begin{array}{l}-2.134 \\
(2.723)\end{array}$ & $\begin{array}{l}-4.060^{*} \\
(2.231)\end{array}$ & $\begin{array}{c}-8.243^{* * * *} \\
(1.394)\end{array}$ & $\begin{array}{c}-7.619 * * * \\
(1.768)\end{array}$ & $\begin{array}{c}-8.378 * * * \\
(2.013)\end{array}$ & $\begin{array}{c}-4.302 * * * \\
(1.269)\end{array}$ & $\begin{array}{c}-3.915^{* * * *} \\
(1.408)\end{array}$ & $\begin{array}{c}-4.318^{* * *} \\
(1.710)\end{array}$ & $\begin{array}{c}-4.611 * * \\
(1.797)\end{array}$ & $\begin{array}{l}-2.570 \\
(2.206)\end{array}$ & $\begin{array}{c}-5.615^{* * * *} \\
(1.882)\end{array}$ \\
\hline Observations & 752 & 276 & 476 & 752 & 276 & 476 & 751 & 275 & 476 & 752 & 276 & 476 \\
\hline Pseudo $\mathrm{R}^{2}$ & 0.0442 & 0.0485 & 0.0536 & 0.178 & 0.252 & 0.155 & 0.0618 & 0.0673 & 0.0687 & 0.0799 & 0.0830 & 0.0948 \\
\hline Wald $X^{2}(12)$ & 30.47 & 7.652 & 36.28 & 163.3 & 234.4 & 117.9 & 60.76 & 45.89 & 28.34 & 157 & 38.35 & 126.1 \\
\hline Prob $>X^{2}$ & 0.000 & 0.468 & 0.000 & 0.000 & 0.000 & 0.000 & 0.000 & 0.000 & 0.000 & 0.000 & 0.000 & 0.000 \\
\hline
\end{tabular}


Table S3.5: Professional Experience and National Gender Quotas: Religiosity Measure

\begin{tabular}{|c|c|c|c|c|c|c|c|c|c|c|c|c|}
\hline \multirow[t]{2}{*}{ VARIABLES } & \multicolumn{3}{|c|}{$\begin{array}{c}(1) \\
\text { Legal }\end{array}$} & \multicolumn{3}{|c|}{$(2)$} & \multicolumn{3}{|c|}{ (3) } & \multicolumn{3}{|c|}{$\begin{array}{c}(4) \\
P h D\end{array}$} \\
\hline & All & Female & Male & All & Female & Male & All & Female & Male & All & Female & Male \\
\hline National Gender Quota & $\begin{array}{c}0.464 * * * \\
(0.090)\end{array}$ & $\begin{array}{c}0.833 * * * \\
(0.183)\end{array}$ & $\begin{array}{c}0.314 * * * \\
(0.096)\end{array}$ & $\begin{array}{c}-0.103 \\
(0.080)\end{array}$ & $\begin{array}{c}0.077 \\
(0.144)\end{array}$ & $\begin{array}{c}-0.192 * * * \\
(0.068)\end{array}$ & $\begin{array}{c}0.325^{* *} \\
(0.127)\end{array}$ & $\begin{array}{c}0.363 * * \\
(0.171)\end{array}$ & $\begin{array}{c}0.307 * * \\
(0.147)\end{array}$ & $\begin{array}{c}0.260 \\
(0.160)\end{array}$ & $\begin{array}{l}-0.191 \\
(0.177)\end{array}$ & $\begin{array}{c}0.459 * * \\
(0.200)\end{array}$ \\
\hline Closed List & $\begin{array}{c}0.111 \\
(0.206)\end{array}$ & $\begin{array}{l}-0.359 \\
(0.371)\end{array}$ & $\begin{array}{c}0.300 \\
(0.254)\end{array}$ & $\begin{array}{c}0.273 \\
(0.177)\end{array}$ & $\begin{array}{c}-0.330 \\
(0.379)\end{array}$ & $\begin{array}{c}0.567 * * * \\
(0.156)\end{array}$ & $\begin{array}{c}-0.693 * * \\
(0.325)\end{array}$ & $\begin{array}{c}-0.851^{*} \\
(0.458)\end{array}$ & $\begin{array}{l}-0.596 \\
(0.366)\end{array}$ & $\begin{array}{l}-0.187 \\
(0.322)\end{array}$ & $\begin{array}{c}0.020 \\
(0.572)\end{array}$ & $\begin{array}{c}-0.222 \\
(0.327)\end{array}$ \\
\hline Disproportionality & $\begin{array}{l}-0.061 \\
(0.044)\end{array}$ & $\begin{array}{c}-0.218 * * \\
(0.085)\end{array}$ & $\begin{array}{c}0.004 \\
(0.056)\end{array}$ & $\begin{array}{c}-0.002 \\
(0.037)\end{array}$ & $\begin{array}{c}0.029 \\
(0.064)\end{array}$ & $\begin{array}{l}-0.013 \\
(0.042)\end{array}$ & $\begin{array}{c}0.017 \\
(0.063)\end{array}$ & $\begin{array}{l}-0.012 \\
(0.094)\end{array}$ & $\begin{array}{c}0.045 \\
(0.067)\end{array}$ & $\begin{array}{c}-0.133 * * \\
(0.059)\end{array}$ & $\begin{array}{l}-0.064 \\
(0.116)\end{array}$ & $\begin{array}{c}-0.165^{* *} * \\
(0.073)\end{array}$ \\
\hline \# of Districts & $\begin{array}{l}-0.020 \\
(0.016)\end{array}$ & $\begin{array}{c}-0.013 \\
(0.037)\end{array}$ & $\begin{array}{l}-0.025 \\
(0.020)\end{array}$ & $\begin{array}{c}0.001 \\
(0.013)\end{array}$ & $\begin{array}{c}0.019 \\
(0.032)\end{array}$ & $\begin{array}{l}-0.003 \\
(0.012)\end{array}$ & $\begin{array}{c}-0.082 * * * \\
(0.029)\end{array}$ & $\begin{array}{l}-0.026 \\
(0.037)\end{array}$ & $\begin{array}{c}-0.109 * * * \\
(0.037)\end{array}$ & $\begin{array}{l}-0.028 \\
(0.031)\end{array}$ & $\begin{array}{l}-0.047 \\
(0.043)\end{array}$ & $\begin{array}{l}-0.023 \\
(0.037)\end{array}$ \\
\hline Women in Natl Parliament & $\begin{array}{l}-0.026 \\
(0.017)\end{array}$ & $\begin{array}{c}-0.099 * * * \\
(0.026)\end{array}$ & $\begin{array}{c}0.006 \\
(0.023)\end{array}$ & $\begin{array}{c}-0.004 \\
(0.012)\end{array}$ & $\begin{array}{l}-0.001 \\
(0.023)\end{array}$ & $\begin{array}{l}-0.003 \\
(0.013)\end{array}$ & $\begin{array}{c}-0.028 \\
(0.021)\end{array}$ & $\begin{array}{l}-0.017 \\
(0.033)\end{array}$ & $\begin{array}{c}-0.034 \\
(0.021)\end{array}$ & $\begin{array}{c}-0.041 * * \\
(0.017)\end{array}$ & $\begin{array}{l}-0.037 \\
(0.035)\end{array}$ & $\begin{array}{c}-0.040^{*} \\
(0.022)\end{array}$ \\
\hline Women with degree & $\begin{array}{l}-0.009^{*} \\
(0.005)\end{array}$ & $\begin{array}{l}-0.010 \\
(0.009)\end{array}$ & $\begin{array}{l}-0.008 \\
(0.007)\end{array}$ & $\begin{array}{c}0.004 \\
(0.003)\end{array}$ & $\begin{array}{c}0.003 \\
(0.007)\end{array}$ & $\begin{array}{c}0.004 \\
(0.004)\end{array}$ & $\begin{array}{c}0.012^{* *} \\
(0.006)\end{array}$ & $\begin{array}{c}0.019 * * * \\
(0.007)\end{array}$ & $\begin{array}{c}0.006 \\
(0.007)\end{array}$ & $\begin{array}{c}0.009 \\
(0.007)\end{array}$ & $\begin{array}{c}0.005 \\
(0.008)\end{array}$ & $\begin{array}{c}0.012 \\
(0.008)\end{array}$ \\
\hline Regular Service Attendance & $\begin{array}{l}-0.004 \\
(0.007)\end{array}$ & $\begin{array}{l}-0.020 \\
(0.013)\end{array}$ & $\begin{array}{c}0.003 \\
(0.010)\end{array}$ & $\begin{array}{c}0.001 \\
(0.005)\end{array}$ & $\begin{array}{c}-0.002 \\
(0.010)\end{array}$ & $\begin{array}{c}0.003 \\
(0.006)\end{array}$ & $\begin{array}{l}-0.009 \\
(0.010)\end{array}$ & $\begin{array}{l}-0.024^{*} \\
(0.013)\end{array}$ & $\begin{array}{c}0.001 \\
(0.012)\end{array}$ & $\begin{array}{l}-0.009 \\
(0.008)\end{array}$ & $\begin{array}{l}-0.002 \\
(0.016)\end{array}$ & $\begin{array}{l}-0.014 \\
(0.012)\end{array}$ \\
\hline Age & $\begin{array}{c}-0.021^{* *} \\
(0.010)\end{array}$ & $\begin{array}{l}-0.002 \\
(0.019)\end{array}$ & $\begin{array}{c}-0.031 * * * \\
(0.010)\end{array}$ & $\begin{array}{l}-0.002 \\
(0.008)\end{array}$ & $\begin{array}{l}-0.013 \\
(0.015)\end{array}$ & $\begin{array}{c}0.003 \\
(0.008)\end{array}$ & $\begin{array}{c}0.024 * * * \\
(0.009)\end{array}$ & $\begin{array}{c}0.013 \\
(0.020)\end{array}$ & $\begin{array}{c}0.026 * * * \\
(0.007)\end{array}$ & $\begin{array}{c}0.012 \\
(0.008)\end{array}$ & $\begin{array}{c}0.016 \\
(0.020)\end{array}$ & $\begin{array}{c}0.009 \\
(0.009)\end{array}$ \\
\hline Constant & $\begin{array}{c}2.033 \\
(1.291)\end{array}$ & $\begin{array}{c}4.519 * * \\
(2.169)\end{array}$ & $\begin{array}{c}1.031 \\
(1.564)\end{array}$ & $\begin{array}{l}-1.494 \\
(0.986)\end{array}$ & $\begin{array}{c}-0.977 \\
(2.130)\end{array}$ & $\begin{array}{c}-1.861 * * \\
(0.942)\end{array}$ & $\begin{array}{c}-2.599 \\
(1.736)\end{array}$ & $\begin{array}{l}-3.141 \\
(2.602)\end{array}$ & $\begin{array}{l}-2.139 \\
(1.873)\end{array}$ & $\begin{array}{l}-1.168 \\
(1.714)\end{array}$ & $\begin{array}{l}-1.480 \\
(2.958)\end{array}$ & $\begin{array}{l}-1.210 \\
(1.808)\end{array}$ \\
\hline Observations & 745 & 273 & 472 & 745 & 273 & 472 & 745 & 273 & 472 & 745 & 273 & 472 \\
\hline Pseudo $\mathrm{R}^{2}$ & 0.0404 & 0.0869 & 0.0437 & 0.00413 & 0.00994 & 0.0131 & 0.0626 & 0.0780 & 0.0670 & 0.0338 & 0.0337 & 0.0444 \\
\hline Wald $X^{2}(12)$ & 137.4 & 31.46 & 86.48 & 8.725 & 4.517 & 42.18 & 42.79 & 24 & 49.79 & 35.85 & 9.865 & 16.53 \\
\hline Prob $>X^{2}$ & 0.000 & 0.000 & 0.000 & 0.366 & 0.808 & 0.000 & 0.000 & 0.00229 & 0.000 & 0.000 & 0.275 & 0.0354 \\
\hline
\end{tabular}

